HAGYOMÁNYOK ÉS KIHÍVÁSOK

IV. ORSZÁGOS KÖNYVTÁRSZAKMAI NAP, 2015 



\section{HAGYOMÁNYOK ÉS KIHÍVÁSOK}

\section{ORSZÁGOS KöNYVTÁRSZAKMAI NAP, 2015}

Szerkesztette:

Szabó Panna és Székelyné Török Tünde

ELTE Egyetemi Könyvtár

Budapest, 2016 
Hagyományok és kihívások

IV. Országos Könyvtárszakmai Nap, 2015

Szerkesztette:

Szabó Panna és Székelyné Török Tünde

Készült a

Nemzeti Kulturális Alap

támogatásával

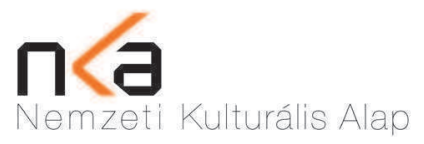

A 2015. augusztus 31-én rendezett konferencia az Egyetemi Könyvtárért Alapítvány támogatásával valósult meg.

ISBN 978-963-284-754-2

(C) A szerzők és a szerkesztők, 2016

Az absztraktokat fordította: Herendi Katalin, Széles Ágnes.

A konferencia és a pályázat lebonyolításában közremüködött: Acsai János, Kollár Tamásné.

A kötet elektronikus formában elérhető

az ELTE repozitóriumában: https://edit.elte.hu

Kiadta az ELTE Egyetemi Könyvtár.

Felelős vezető: Kálóczi Katalin.

1053 Budapest, Ferenciek tere 6.

http://konyvtar.elte.hu
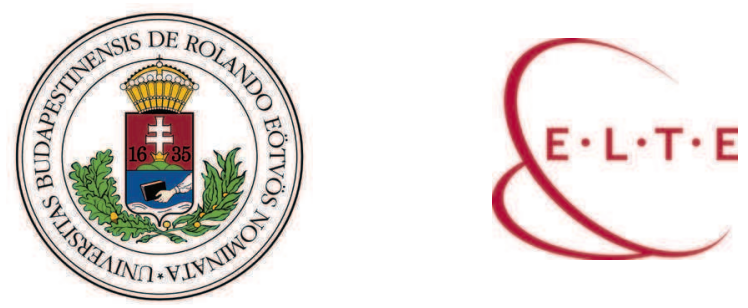


\section{Tartalom}

Előszó

Az Egyetemi Könyvtár múltja, eredményei, új szolgáltatásai

KISZL PÉTER: „Jóval több hajlam és tanulmány kivántatik, mint sok más pályához”.

Az Egyetemi Könyvtár szerepe a hazai könyvtárosi szakképesítés kialaku-

lásában

KNAPP ÉVA: Miként kaptak jelzetet az ELTE Egyetemi Könyvtár corvinái?.

CZINKI-VIETORISZ GABRIELLA: Könyvtárhasználók igényeire szabott szolgáltatás-

fejlesztés az Egyetemi Könyvtárban

SZÉPVÖLGYI KATALIN: „,... gondjaink tesznek minket bátrakká ... ” Időszaki kiadványok elektronikus naplózása az ELTE Egyetemi Könyvtárban

VARGA KLÁRA: Tervek és tények. Az ELTE Egyetemi Könyvtári Szolgálat kulturális szakembereinek képzése a szolgáltatások fejlesztése érdekében címü TÁMOP-3.2.12-12/1/KMR-2012-0007 pályázat eredményei

\section{Tudományos, intézményi repozitóriumok és jogi kérdéseik}

VIRÁG GABRIELLA: EDIT apró lépései, nagy ugrásai ......................................... 63

KARÁCSONY GYÖNGYI: A Debreceni Egyetem elektronikus Archívuma ................ 73

HOLL ANDRÁs: MTMT: megújulás és lehetőségek ........................................... 83

AMBERG ESZTER: A repozitóriumok üzemeltetésének jogi kérdései....................... 89

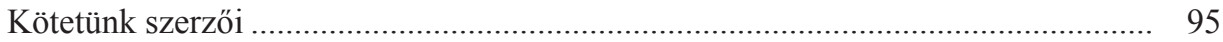





\section{Előszó}

Az ELTE Egyetemi Könyvtár 2011-ben, fennállásának 450. évfordulóján a hagyományteremtés szándékával országos konferenciát rendezett, melynek kettős célja volt. Részben az elért szakmai eredményeit szerette volna bemutatni szélesebb érdeklődő közönség előtt, részben pedig fórumot kívánt biztosítani a szakmai közvéleményt leginkább foglalkoztató kérdések megvitatására. Évről évre számos Budapesten és vidéken élő kollégánk vett részt az eseményen elöadóként, hallgatóként. A közönség soraiban üdvözölhettünk egyetemi hallgatókat is, akik a szervezés munkájába is készségesen bekapcsolódtak.

2015-ben immár negyedik alkalommal rendeztük meg a Hagyományok és kihívások címü konferenciát, melyen az Egyetemi Könyvtár történeti vonatkozásairól, eredményeiről és új szolgáltatásairól egyaránt hangoztak el előadások. Átfogó képet kaptunk az MTMT-adatbázis céljairól, fejlesztési terveiről, a repozitórium-építés kapcsán pedig bepillanthattunk más intézmények gyakorlatába. Mivel e dokumentumszerverek üzemeltetői többnyire a könyvtárak, indokoltan kapott hangsúlyos szerepet a müködtetésük kapcsán felmerülö jogi kérdések ismertetése. Az esemény zárásaként kerekasztal-beszélgetés zajlott neves szakemberek közremüködésével az elektronikus dokumentumok könyvtári szolgáltatása kérdéskörben.

Úgy véljük, ezek a konferenciák mindenképpen hozzájárultak ahhoz, hogy az Egyetemi Könyvtár meghatározó vonatkoztatási ponttá vált országos szakmai körökben: egyre több rendezvényre kapunk felkérést elöadóként, számos felsőoktatási és szakkönyvtár igényli szakmai tanácsainkat, kezdeményez konzultációt.

Az elkövetkezendö években töretlen marad a célunk. Szeretnénk bemutatni azt a munkát és partneri együttmüködéseinket, amely nagy múltú intézményünkben nap mint nap zajlik, amellyel mi, könyvtárosok hozzájárulunk ahhoz, hogy az Eötvös Loránd Tudományegyetem tudásvagyona minél szélesebb körben ismertté és hozzáférhetővé váljon.

KÁLÓCZI KATALIN föigazgató ELTE Egyetemi Könyvtár 



\section{AZ EGYETEMI KÖNYVTÁR MÚLTJA, EREDMÉNYEI, ÚJ SZOLGÁLTATÁSAI}





\section{„Jóval több hajlam és tanulmány kivántatik, mint sok más pályához"}

\section{Az Egyetemi Könyvtár szerepe a hazai könyvtárosi szakképesítés kialakulásában ${ }^{1}$}

Szakmánk állandó velejárója a könyvtárosképzés megújulási törekvése, a folyamatos alkalmazkodás a megváltozott környezeti tényezőkhöz, a felhasználói és a fenntartói elvárásokhoz. Az oktatás szerves része a számonkérés, mely a képesítésre való alkalmasság megállapításának mai napig leghatékonyabbnak tartott módszere. A múlt vizsgálata tehát ebböl a szempontból is tanulságos lehet: elődeink milyen procedúra után nyilvánítottak egy pályázót a mai értelemben vett könyvtáros munkatársnak? Levéltári forrásokra támaszkodva tárjuk fel a budapesti Egyetemi Könyvtár 140 évvel ezelőttre visszanyúló, a könyvtárosság mint önálló foglalkozás kialakulása szempontjából mérföldkőnek számító kinevezési gyakorlatát.

\section{Könyvtárosság a szakmák sorában}

Európa több államában, nálunk is, sokáig a legkülönbözőbb múlttal és elöképzettséggel rendelkező személyek gondoznak könyvanyagokat, rendszerint a tulajdonos bizalmi embereként, gyakran érdemekből kifolyólag, nem teljes elfoglaltságban. Magyarországon a könyvtárosi szakma mint önálló foglalkozás (azaz a könyvtári munkájáért rendszeresen fizetett, abból élő, fóállású könyvtáros) a könyvanyag növekedése és a gyüjtemények nyilvánossá válása okán, a polgárosodás indukálta igények hatására, a XVIII. század második felében kezd letisztulni. Ebben kiemelt szerep jut az Országos Széchényi Könyvtár 1802-es megalapításáig egyedüli magyar nyilvános gyüjteményünknek, az Egyetemi Könyvtárnak, ahová 1774-ben írnokként kinevezést kap Kovachich Márton György és Szatmári András, majd 1779-ben harmadik őrként Heinrich Gottfried von Bretschneider. (A teljességhez hozzátartozik, hogy Klimó György 1774-ben 10000 forintos

\footnotetext{
${ }^{1}$ Jelen tanulmány a következő közlemény rövidített változata: Kiszl Péter: A könyvtárosi szakvizsga magyarországi gyökereiről képesítési rendszerünk 140 éves jubileumán. = Könyvtári Figyelö, 25. évf. 2015. 2. sz. 217-228. p.
} 
alapítványt tett egy könyvtáros és egy szolga fizetésére, de a téka a pécsi püspök halálát követően, egészen 1808-ig felügyelet nélkül maradt, majd egy papot neveztek ki könyvtárosnak, így nem lehet meghatározó a világi könyvtárosgárda szárba szökkenésében.) $)^{2}$

\section{Az első könyvtárosi szakvizsga}

A szakismeretek elsajátítására - a nyilvános könyvtárak és könyvtárosok csekély számából kiindulva - sokáig tehát kizárólag a bibliotékában dolgozva, egy szük kör számára volt lehetőség. Azt is tudjuk, hogy többek akár jövedelem nélkül is vállaltak könyvtári állásokat - a későbbi alkalmazást remélve. Vértesy Miklós 140 évvel ezelöttre, 1874-re datálja az első hazai szakvizsgát, melyet a Horvát Árpád vezetése (1874-1876) alatt álló Budapesti Magyar Királyi Tudományegyetem Könyvtárában (ma Eötvös Loránd Tudományegyetem Egyetemi Könyvtár) tettek le. Vértesytől eredeztetve ugyanezt az időpontot említi Kőhalmi Béla és Kovács Máté ${ }^{5}$, ahogy az 1982-ben megjelent könyvtártörténeti monográfiában ismét ezt írja Vértesy ${ }^{6}$ (forráshivatkozás nélkül). A Könyvtáros-beli közleményében Vértesy az 1898. február 2-án tartott kezelötiszti vizsgáról szól bövebben, így tudomásunk szerint mindezidáig nem kapott szakmai nyilvánosságot az első, 1874-ben bonyolított - történetileg úttörö jelentőségü könyvtárosi pályázat.

\section{Az Egyetemi Könyvtár korabeli szervezete}

Mielőtt rátérnénk a könyvtárosi vizsgák tárgyalására, fontos tisztázni a gyüjtemény munkatársainak hierarchiáját. Legalul helyezkedtek el a szolgák, kisegítők (az üzemeltetésért felelős kapusok, fütők, takarítók, illetve raktárosok, teremfelügyelök).

A gyakornokok - a későbbi könyvtárosként való foglalkoztatás reményében - gyakran ellenszolgáltatás nélkül dolgoztak. A dijnokok (pl. irnokok)

${ }^{2}$ V. Windisch Éva: Fejezet a könyvtárosi pálya magyarországi kialakulásának történetéből. = Magyar Könyvszemle, 73. évf. 1957. 2. sz. 137-138. p.

${ }^{3}$ Vértesy Miklós: Könyvtáros-vizsga 60 évvel ezelőtt. = A Könyvtáros, 8. évf. 1958. 8. sz. 574. p.

${ }^{4}$ Köhalmi Béla: A Magyar Tanácsköztársaság könyvtárügye. Budapest, Gondolat Kiadó. 1959. 179. p.

${ }^{5}$ Kovács Máté: Az egyetemi könyvtárosképzés két évtizedes fejlődése és föbb kérdései. Budapest, 1970. Forrás: http://mek.oszk.hu/06700/06707/06707.htm [2016. 01. 18.]

${ }^{6}$ Tóth András - Vértesy Miklós: A Budapesti Egyetemi Könyvtár története (15611944). Budapest, Egyetemi Könyvtár. 1982. 342. p. 
alkalmazását nem kötötték szakvizsgához, „,öbbnyire egyetemet végzettek voltak és könyvtári gyakorlat nélkül, a tulajdonképpeni címleiró feladatát végezték. "7 Mindkét kategóriában ideiglenes munkatársak is lehettek.

Szakszemélyzetként, a mai értelemben vett könyvtárosokként öket követték a kezelötisztek (hivatalnokok), akiknek három besorolása ismeretes (felsorolásunk szerinti csökkenő presztízzsel): első, második és harmadik tiszt. Számukra írták elő - a már említett pályázati rendszerben - a kezelöi vizsgákat. Felettük álltak a könyvtárörök (szintén három osztatú besorolásban), akik ugyancsak eredményes szakvizsga után kerülhettek a magasnak számító pozíciójukba, középvezetői rangban. A könyvtár irányítását az igazgató látta el, akinek kinevezése felségjog alapján történt a helytartótanács, majd a vallás- és közoktatásügyi miniszter előterjesztésére. A könyvtár az Egyetemi Tanács alárendeltségében müködött. Az igazgató helyettesítését a könyvtárőrök egyike látta el, így ezen posztok betöltéséhez a felsőbb körök támogatása sem ártott. Az igazgató és az első őr rendszerint az egyetemi tanárok köréböl került ki. A személyzet egy része (maga az igazgató is) bent lakott a könyvtár épületében.

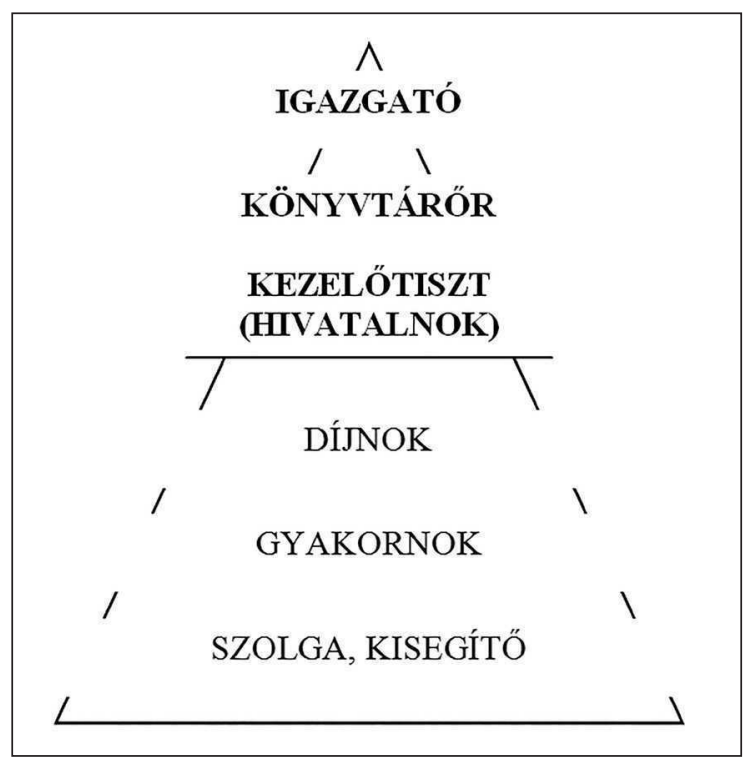

1. ábra. Az Egyetemi Könyvtár munkatársainak korabeli hierarchiája

${ }^{7}$ Klimes-Szmik Katalin: Az új könyvtárpalota felépítésétől a századfordulóig 1874 1899. = Az Egyetemi Könyvtár egy évszázada, 1874-1980. Szerk. Szögi László. Budapest, ELTE Egyetemi Könyvtár. 2008. 16. p. 
Az 1. ábrán modellezett, az idők (évtizedek, sőt évszázadok) során persze kismértékben módosuló, de elveiben mindvégig fennálló szervezeti felépítést támasztja alá Tóth András és Vértesy Miklós A Budapesti Egyetemi Könyvtár története címü kötetének ${ }^{8}$ több megállapítása is.

\section{A könyvtárosi szakvizsgák kezdetei az Egyetemi Könyvtárban - első őri pályázat 1874-ben}

Vértesy Miklós tényközlésének utánajárva, levéltári kutatások alapján9 megállapítható, hogy az Egyetemi Könyvtárban egészen 1874-ig - pályázatot nélkülözve - az igazgató elöterjesztésére engedélyezték a megüresedett álláshelyek betöltését. Az új (azaz a ma is használt) könyvtárépület átadása előtt két évvel azonban más helyzet állt elő, amely - ahogy később látni fogjuk - ugyan érdemi változást ugyan nem hozott a kinevezések folyamatában (az igazgató jelöltjei, a könyvtár akkori dolgozói nyerték el az állásokat), de a szakmai elvek lefektetésében hatalmas elörelépést jelentett. Erre bizonyíték Horvát Árpád igazgató 1874. február 2-án, az Egyetemi Tanácsnak - a vallás- és közoktatásügyi miniszter hatására - küldött véleménye „az Egyetemi Könyvtárnál üresedésben lévö elsö öri állásnak mi módon eszközlendö betöltése iránt." nagy munka vár az összes könyvtári személyzetre a könyvtárnak az új épületben leendö felállitása, rendezése, lajstromozása, kiegészitése s a irodalom szinvonalára emelése tekintetéböl”, ennélfogva ,, a könyvtári állomások betöltésénél a becsületességen s buzgálmon kívül a könyvtárnoki szakképzettség lehet csak az egyedül jogosult vezérelv", különös tekintettel az első örre, akinek ,, az intézet egyik oszlopát kell képeznie szellemi tekintetben”.

Az igazgató a ,szakképzettségnek kipuhatolására” a pályázatot tartja egyedüli üdvözítő útnak, amely azonban csak az új aspiránsokra vonatkozzék. Javasolja, hogy miniszteri biztos jelenlétében colloquimot (azaz vizsgát) tartsanak a következö témakörökkel:

- hazai és egyetemes irodalomtörténet,

- könyvészet,

- könyvtártan.

${ }^{8}$ Tóth András - Vértesy Miklós: i. m.

${ }^{9}$ Az ELTE Egyetemi Levéltárában a legrégebbi irattári napló az 1884-1887 közötti időszakra vonatkozik, a megelőző évek esetében a mai értelemben vett iktatókönyv nem lelhetö fel.

${ }^{10}$ A budapesti Tudomány-Egyetem Tekintetes Tanácsához véleményes jelentése Horvát Árpád egyetemi könyvtárnoknak az üresedésben lévő első őri állomás betöltését illetőleg. 1874. február 2. ELTE Egyetemi Levéltár 19/a, 1874. 
Kívánatosnak látja, hogy minden kinevezendő hivatalnokánál az első esztendő próbaévnek számítson.

A vizsgát azért is szorgalmazza, mert ,, számosan vannak nálunk azon balhiedelemben, hogy a könyvtárnok szakképzettsége alig áll egyébböl, mint a könyvcímek hibátlan lemásolásából, s a könyveknek a catalogus szerint eszközlendö kikereséséböl; innen magyarázható az is, hogy vajhmi sokan vélik nálunk, miszerint minden több kevesebb iskolát végzett s némi egyetemes müveltséggel bíró emberböl alkalmas könyvtári hivatalnok válhatik, - ami pedig igen igen nagy tévedés -, miután a pályához jóval több hajlam és tanulmány kivántatik, mint sok más pályához. - Szükségesnek tartja végre alulirott a colloquimot azért is, nehogy az Egyetemi Könyvtár a pályázat kihirdetése után, a hirlapi reclame által elötérbe tolt himpellérek szünni nem akaró ostromának legyen kitéve."

Előterjesztésében többször von párhuzamot a magántanári kinevezésekkel, amelyek során bevált vizsgarendszer, próbaidő müködik, és önéletrajzot, iskolai, illetve egyéb bizonyitványokat szükséges csatolni.

Az elöterjesztés végül azzal zárul, hogy ilyen körülmények között Szinnyei József könyvtártiszt első őri kinevezésére sem kerülhet sor, kizárólag a , kihirdetendö pályázat eredményétöl függvén”.

Az Egyetemi Tanács Trefort Ágoston miniszterhez továbbítja a tervezetet, aki 1874. április 18-án született válaszában ${ }^{11}$ elrendeli az első őri állás pályázati úton történő betöltésének megszervezését, s május 31-i beadási határidővel meg is jelenik a pályázati kiírás. A következő fellelt dokumentum szerint az Egyetemi Tanács 1874. október 3-án tartott, Kováts József rektor által elnökölt ülésén 1874. október 10-én 10 órára rendeli el a colloquimot, a könyvtárigazgatón kívül két tanácstag (Jendrássik Jenö ${ }^{12}$ orvoskari és Kerékgyártó Árpád ${ }^{13}$ bölcsészetkari prodékán) mint egyetemi biztosok jelenlétében. ${ }^{14}$

Horvát Trefortnak 1874. november 20 -án írt levele ${ }^{15}$ szerint a pályázatra tíz ,folyamadó jelentkezett, kik betürendben a következök”:

1. Dr. Bécsi János királyi törvényszéki orvos

2. Bőhm Mihály erdélyi múzeumi-könyvtárnoki segéd

${ }^{11}$ ELTE Egyetemi Levéltár 19/a, 1874/3947.

${ }^{12}$ Orvos, fizikus, a Magyar Tudományos Akadémia rendes tagja, a budapesti Élettani Intézet létrehozója.

${ }^{13}$ Müvelődéstörténész, az Magyar Tudományos Akadémia levelező tagja.

${ }^{14}$ ELTE Egyetemi Levéltár 19/a, 1874/11.

${ }^{15}$ Horvát Árpád egyet. könyvtárigazgató jelentést teszen az első őri állomásra hirdetett pályázatról. ELTE Egyetemi Levéltár 19/a, 1874/245. 
3. Jeszenák Ráfáel reáltanodai igazgatótanár

4. Király József budai királyi járásbírósági végrehajtó

5. Dr. Kiss István egyetemi magántanár

6. Kubinyi Lajos

7. Óvári Lipót

8. Ozoray Árpád hírlapíró

9. Dr. Márki József első könyvtártiszt és címzetes őr

10. Szinnyei József másod könyvtártiszt.

Utóbbiak ketten ,,fokozatos elöléptetésért folyamodnak”.

Október 10-én a két könyvtártiszten kívül senki sem jelent meg a vizsgán, így november 3-ára ismételt kollokviumot tüztek ki, ahol négyen vettek részt: Bécsi, Jeszenák, Márki és Szinnyei. „Jeszenák Ráfáel azonban jobban megfontolván a dolgot, a pályázattól az utolsó percben visszalépett, s folyamodványát a csatolmányokkal együtt visszavette."

A kérdéseket előzetesen Mészáros Ferenc miniszteri tanácsos véleményezte, , ,ki meggyözödött arról, hogy a kérdések egytöl egyig a könyvtárnoki segédeszközök s a könyvtárnoki teendök körül forognak miért is azoknak megfejtése az Egyetemi Könyvtár első örétöl teljes joggal követelhetö; e nézetben osztoztak a Tanács küldöttei is; és így mindent megtettünk, a mit csak lehetett a legalkalmasabb egyéneknek kipuhatolására" - tájékoztatja Horvát a minisztert, majd így folytatja: „A föltett kérdésekre Dr. Bécsi János kir. törvényszéki orvos egyáltalán semmit sem bírt felelni." Nem úgy Márki és Szinnyei, akik feleleteit a bizottság teljes mértékben kielégítőnek találta, így messzemenően javasolják kinevezésüket.

Horvát Árpád leszögezi, hogy , könyvtárunk két buzgó hivatalnokával nem versenyezhettek azok kik (az egy Bőhm kivételével) soha közkönyvtárnál nem szolgáltak, - az engem legkevésbbé sem lepett meg, miután jól tudom, hogy könyvtárnoki szakismereteket a könyvtárnoki hivatalnokok körén kívül hazánkban hiába keresnénk.” Azután rátér a két munkatárs eddigi tevékenységének dicséretére, s anyagi megbecsülésük hiányára: „,nemcsak bármely elemi tanitó, hanem a legtöbb kereskedöi-segéd is anyagi tekintetben sokkal kedvezőbb helyzetben vagyon, mint az egyetemi könyvtár tisztviselöi."

Lényegében ugyanezeket tartalmazza Horvát Árpád 1874. december 16-án az Egyetemi Tanácsnak írott jelentése, ${ }^{16}$ melynek egyik mellékle-

${ }^{16}$ Horvát Árpád könyvtárigazgatónak véleményes jelentése az első őri állomás betöltéséről (két melléklettel). 1874. december 16. ELTE Egyetemi Levéltár 19/a, 1874. 
teként a vizsga jegyzőkönyvét, másikként pedig a jelentkezők ,,minősitvényi-tábláját" jelöli meg. Utóbbi sajnos nem lelhető fel az irattárban, így az előmeneteleket továbbra is homály fedi.

\section{Hivatalnoki szakvizsgák az Egyetemi Könyvtárban - harmadik könyv- tártiszti pályázat 1897/98-ban}

Ugyancsak az ELTE Egyetemi Levéltárában kutatható dokumentumok alapján a következőkben bemutatunk egy több mint két évtizeddel későbbi, így már kiforrottabbnak tekinthető harmadik könyvtártiszti szakvizsgát, illetve annak sajátos körülményeit.

1897. június 13-án kelt iratában a belga követség - a magyar külügyminiszteren keresztül - a vallás- és közoktatásügyi miniszterhez fordult annak kiderítésére, hogy „a könyvtári szakra készülö jelöltektöl megkivánható vizsgálat nálunk mikép van szervezve”. A miniszter 1897. június 23-i, az Egyetemi Tanácsnak címzett felhívásában ,,visszavárólag”, „,sürgős véleményes jelentés végett” az egyetemi könyvtárigazgatónak kéri kiadni a külföldi megkeresést, amelyet Bognár István rektor 1897. június 30-án meg is tett.

Szilágyi Sándor igazgató Wlassics Gyula miniszter rendeletére 1897. július 1-jei „alázatos, tájékoztató jelentésében”"17 kifejti a „,könyvtári szakvizsga letételének módozatait”. A történeti forrásból kiderül, hogy hasonló módon szerveznek szakvizsgákat a Magyar Nemzeti Múzeum Könyvtáránál (azaz a mai Országos Széchényi Könyvtárnál) is, azonban más nyilvános közkönyvtáraknál erről nincs tudomás. A 2. ábrában olvasható szöveg is azt bizonyítja, hogy kizárólag férfiak jöhettek könyvtárosként számításba, hiszen katonaviselt vagy hadkötelezettség alól felmentett személy folyamodhatott munkáért. ${ }^{18}$

${ }^{17}$ Felterjesztés a vallás és közokt. m. kir. ministeriumhoz a könyvtári szakvizsgák szervezésének leirása ügyében. 1897. július 1. ELTE Egyetemi Levéltár 19/a, 1898/231.

${ }^{18}$ Vö. „1901-ben vették fel az érettségivel és olasz, német, román nyelvtudással rendelkező Platz Helént gépírónőnek, de valójában ő készítette az új könyvek címleírását. 1906-ban fogadták el először egy nő jelentkezését könyvtártiszti státuszra, ez a hölgy Czeke Marianne volt, akinek ekkor már magyar tanári diplomája mellett bölcsészdoktorátusa is volt." - olvasható Fabó Edit kutatásaiból (Fabó Edit: Az Egyetemi Könyvtár a dualizmus második felében. = Az Egyetemi Könyvtár egy évszázada, 1874-1980. Szerk. Szögi László. Budapest, ELTE Egyetemi Könyvtár. 2008. 62-63. p.). 
Magyarországon a könyvtári szakra készülő jelölttől azaz gyakornoktól könyvtári szakvizsga nem kivántatván, az szervezve nincsen; azonban a könyvtári tisztviselői állásért pályázóktól már követeltetik ilyen vizsgának a sikeres letevése, melynek kiviteli módozatait a következőkben körvonalazom.

Ugyanis a budapesti $\mathrm{m}$. kir. egyetemi könyvtárnál a hivatalnoki állás elnyeréséért folyamodó elébe a következő előfeltételet szabvák, t.i. köteles beigazolni, hogy

a. magyar honpolgár,

b. a tényleges katonai kötelezettségének eleget tett, vagy hadmentes,

c. büntett vagy vétség miatt elitélve nem volt, hivatalvesztésre szóló ítélet hatálya alatt nincsen, csőd vagy gondnokság alatt nem áll, erkölcsi tekintetben ellene semmi kifogás nem foroghat fenn, d. egyetemet vagy akadémiát végzett és tudori oklevéllel bír, legalább egy évig nyilvános közkönyvtárnál gyakornokoskodott, a magyar nyelvben irodalmi jártassága van, az ókori classicai nyelvekben (:latin, görög:) jártas, ezen felül a német, franczia, angol és olasz nyelvek közül legalább egyet ismer, ezeken kívül a könyvtári szakvizsgát sikerrel kiállotta.

A könyvtári szakvizsga tárgyai pedig ezek:

a. a könyvészet,

b. a könyvtártan, melléktárgyúl véve a paleographiát és az oklevéltan elemeit,

c. az egyetemes és a magyar irodalomtörténetnek a könyvtári szolgálat szempontjából különös fontossággal bíró részletei, végül

d. egy vagy két, részletes czímlapfelvétel a bizottság által meghatározott müről vagy művekröl.

A vizsga, a czímlapozáson kivül, szóbeli colloquiumból áll, egy-egy jelöltre nézve fél óráig tart, és a könyvtárnál alkalmilag (:ad hoc:) alakított bizottság előtt, zárt helyen tétetik le. E bizottság tagjai: az egyetemi tanács két kiküldöttje, a könyvtárigazgató, az első- és másodőr, az elnöki tisztet az egyetemi tanács egyik kiküldöttje teljesíti, a jegyzőkönyvet pedig a rangban ifjabb könyvtártiszt vezeti.

A vizsgabizottság kötelessége előbb a pályázati folyamodványokat, az ezekről a könyvtárigazgató által előzetesen szerkesztett, sorozatos kimutatással együtt átvizsgálni és meggyőződést szerezni arról, hogy a pályázati folyamodók szabályszerü minősítési kellékekkel bírnak, csak ezután térhet át a jelöltek megvizsgálására, melynek eredménye kitüntetésére

a. "jó"

b. "elégséges"

c. "ki nem elégítö"

jelzés használtatik.

Az egyetemi könyvtárnál a gyakornoktól semmi felvételi vizsga nem kivántatik, és ilyenné felvehető az olyan jelentkezö, a ki egyetemet vagy akadémiát végzett, ha még oklevéllel nem is bír.

Az ország másik, nagy közintézeténél, t.i. a M. N. Múzeum könyvtáránál is, kevés eltéréssel a fennebb leírt módon van szervezve a könyvtári szakvizsgálat. A gyakornoktól itt sem kívánnak felvételi vizsgát.

E két, nyilvános közkönyvtáron kivül más helyen a tisztviselői jelölttöl szakvizsgálat nem követeltetik, annál kevésbé a gyakornoktól.

Budapest, 1897. jul. 1.

$$
\begin{gathered}
\text { Szilágyi Sándor } \\
\text { igazgató }
\end{gathered}
$$

2. ábra. Szilágyi Sándor könyvtárigazgató 1897. július 1-jén kelt tájékoztatója a Vallásés Közoktatásügyi Minisztériumnak a magyarországi könyvtárosi szakvizsgákról a belga nagykövetség megkeresésének hatására 
1897. november 18 -án átirat ${ }^{19}$ készül a rektorhoz a harmadik könyvtártiszti állásra tervezett pályázat ügyében, melynek hirdetményét a 3. ábra segítségével tesszük közzé. Az egyetemi végzettség mellett követelményként jelenik meg a magyar, német, görög és latin nyelvtudás, illetve a közkönyvtár kezelésében való jártasság, a nyilvános könyvtári munkavégzés igazolása pedig előnyt jelent. (Az első és a második tiszti állásnál már doktori oklevelet is követeltek.)

\section{Pályázati hírdetés}

A budapesti m. kir. tud. egyetemi könyvtárnál a X. fizetési osztályba tartozó, kezelö- tiszti állás a Nagyméltóságú vallás-és közokt. m. kir. minisztériumnak 41562/1897 sz. alatti rendelete alapján betöltendő.

Pályázni óhajtók felhivatnak, hogy pályázati folyamodványukat a Nagyméltóságú vallás-és közoktatásügyi $\mathrm{m}$. kir. miniszter úrhoz czímezve, 2 heti időtartam alatt a budapesti $\mathrm{m}$. kir. tud. egyetemi rectori irodába nyujtsák be.

Pályázati feltételek:

a. egyetemi végzettség,

b. a magyar és német nyelvnek szó-és írásbelileg teljes ismerete,

c. az ókori classicai nyelvekben (görög, latin) jártasság,

d. a közkönyvtári kezelésben gyakorlottság, a melynek beigazolása végett a könyvtár igazgatósága elött egy vizsga letevése kivántatik.

Megjegyzendő, hogy nyilvános könyvtárnál alkalmazottak elönyben részesülnek.

Budapest, 1897. nov. 18.

rector

3. ábra. Az 1897. november 18-án kelt harmadik könyvtártiszti álláspályázat szövege

Az állásra többen is jelentkeztek, az előzetes minősítés szerencsére itt fennmaradt, az 1. táblázatban foglalták össze. 1898. január 29-én értesítést intéztek a pályázókhoz, majd ennek alapján sor került a megmérettetésre. Az 1898. február 5-én tartott harmadik könyvtártiszti vizsga bizottsága:

- Berger János prorektor (rektor: 1880/1881. tanév), „Esztergom főegyházmegyei áldozár, hittudor, az ószövettségi tanulmányok, sz. írás magyarázat s héber nyelv ny. b. tanára, a hittudományi kar volt dékánja" ${ }^{20}$ mint elnök;

${ }^{19}$ Átírat a rectorhoz a III. könyvtártiszti állásra hirdetendő pályázat ügyében. 1897. november 18. ELTE Egyetemi Levéltár 19/a, 1897/327.

${ }^{20}$ Beszéd, mellyel 1880. szeptember 1-én a Budapesti Kir. Magy. TudományEgyetemen Rectori székét elfoglalta Berger Ev. János, Esztergom főegyházmegyei áldozár, hittudor, az ószövettségi tanulmányok, sz. írás magyarázat s héber nyelv ny. b. tanára, a hittudományi kar volt dékánja. Forrás: https:/edit.elte.hu/xmlui/handle/10831/9430 [2016. 01. 18.] és http://www.elte.hu/rektorok [2016. 01. 18.] 
- Ponori Thewrewk Emil egyetemi tanár, klasszika-filológus, müfordító (az 1899/1900. tanévben az egyetem rektora); ${ }^{21}$

- Szilágyi Sándor miniszteri tanácsos, könyvtárigazgató (1878-1899);

- Máté Sándor és Kudora Károly könyvtárörök, elöbbi 1899-ben, Szilágyi halála után a könyvár megbízott igazgatója, ${ }^{22}$ utóbbi az első magyar könyvtártani munka írója:23

- Dézsi Lajos könyvtártiszt (a szegedi egyetem bölcsészkarának későbbi tanszékvezetője, dékánja és rektora, irodalomtörténész), jegyző.

A meghallgatást taglaló vizsgálóbizottsági jegyzőkönyv ${ }^{24}$ tanúsága szerint Szilágyi Sándor felhívta a figyelmet arra, hogy „, a pályázat kihirdetése alkalmával a betöltendö állás czíméböl kihagyatott a , kezelötiszti” szó, s egyszerüen III. osztályú könyvtártiszti állás-ra hirdettetett pályázat. Ezt a végböl tartja szükségesnek hangsúlyozni, mivel a pályázati feltételek is ehhez szabottak s míg a könyvtártiszti állásra pályázóktól doktori oklevél, a jelenleg szóban forgó kezelötiszti állásnál csupán egyetemi végzettség kivántatott meg a folyamodóktól. Továbbá míg a könyvtártiszti vizsgának a diplomatika, palaeographia, magyar irodalomtörténet, könyvészeti és könyvtártani elméleti ismeretek, stb képezik tárgyát, addig a kezelötiszti vizsgálat gyakorlati szempontokra tekintettel e tudományágak elhagyásával a classicus és egy modern nyelv ismeretét s könyvtári gyakorlati ismereteket kíván a pályázóktól. Ezen indokokra tekintettel kéri jegyzökönyvbe venni, hogy a mostan tartandó kezelötiszti vizsgálat nem képesit az I. és II. osztályu könyvtártiszti állásra s a mostani vizsgálatot sikerrel kiállott pályázó magasabb (könyvtártiszti) vizsgálat letéte nélkül üresedés esetében nem reflectálhat az állásra, illetöleg elöléptetésre, sem a könyvtártiszti teendökre nézve az alapszabályokban biztositott jogokra és hatáskörre nem tarthat igényt."

A bizottság elfogadta az igazgató előterjesztését: ,,ennek értelmében kimondatik, hogy jelen alkalommal kezelötiszti vizsgálat tartatik, mely nem

${ }^{21}$ Szinnyei József: Magyar írók élete és munkái. Magyar Könyvkiadók Egyesülete, Budapest 1891-1914. 106. p. Ponori Thewrewk Emil szócikk. Forrás: http://mek.oszk.[-] hu/03600/03630/html/t/t27708.htm [2016. 01. 18.]

${ }^{22}$ Főigazgatóink a könyvtár állami intézménnyé válásától. Forrás: http://www.konyv[-] tar.elte.hu/regi/magunkrol/tortenet/foigok.html\#mate [2016. 01. 18.]

${ }^{23}$ Kudora Károly: Könyvtártan. Budapest, Dobrowsky és Franke. 1893. Forrás: http://mek.oszk.hu/11900/11913/11913.pdf [2016. 01. 18.]

${ }^{24}$ Jegyzőkönyv az 1898. február 5-én a kir. magyar tudományegyetemi könyvtár helyiségében tartott könyvtári vizsgálóbizottsági ülésről. 1898. február 5. ELTE Egyetemi Levéltár 19/a, 1898/68. 
képezi a magasabb (I. és II.oszt.) könyvtártiszti állásra, s a mostani vizsgálatot sikerrel letett pályázó a magasabb könyvtártiszti minösités megszerzése nélkül a majdan megüresedendö I. és II. osztályú könyvtártiszti állásra nem reflektálhat; továbbá az egyetemi tanács felkéretik, hogy a M. vallás és közoktatásügyi Minisztériumhoz intézendö felterjesztésében a kinevezendö pályázó kezelötiszti czímét és jellegét hangsúlyozza."

Az öt jelentkezö közül 1898. január 31-én Steiner Károly visszalépett, Turchányi Tihamér betegség miatt nem tudott megjelenni, a fennmaradó három pályázóból Tetzel Lörinc és Greifel György tudta végzettségét szabályszerúen igazolni. Kováts László tanárjelölt nem rendelkezik végbizonyítvánnyal, azonban ,,Szilágyi Sándor könyvtárigazgató megjegyzi, hogy értesülése szerint az egyetem bölcsészeti karának dékánja már kiállitotta a Kováts egyetemi végzettségét tanúsitó hivatalos igazolványt s az minden órában várható”. A bizottság végül úgy dönt, hogy „Greifel György és Tetzel Lörinc okmányaik alapján, Kováts László pedig föltételesen vizsgálatra bocsáttatnak, ez utóbbi oly kikötéssel, hogy márcziusig szerezze be végbizonyitványai, mely egyetemi végzettségét igazolja”.

„,Kováts László behívatván elöadja, hogy abban az esetben, ha csakugyan kezelötiszti állásra hirdetik pályázat, visszalép. Berger János még egyszer megkérdi, hogy ez által ne engedje magát elrémitetni s visszalép-é? Megmarad elöbbi elhatározása mellett." - ennek következtében Greifel és Tetzel marad versenyben, akik felváltva a következö feladatokat kapják.

Írásbeli forditás latinból (Cicero Opera Omnia I. kötet cím és elöszó), görögből (Homéros egy sora), németböl (Karst: Geschichte Manfreds első fejezet), majd könyvfölvételi példák.

Szóbeli kérdések a könyvészeti kézikönyvek, a könyvrendelés, a könyvtártan és a könyvtári ügyrend témaköreiből:

- „Mi a bibliográfia?

- Micsoda könyvészeti müvek vannak?

- Német, francia, angol, olasz könyvészeti müvek.

- Ha egy müböl hiányzik a III. kötet, mit csinálunk vele?

- Egy új könyvvel rendezés szempontjából mit csinálunk?

- A folyóiratokat hogy kezeljük?

- Encyklopédiák.

- Egy rendelet ha jönne az egyetemi tanácstól, mit csinálna vele?

- Ha egy régi könyvet óhajtana a kar megrendelni, mit csinálna vele?" 


\begin{tabular}{|c|c|c|c|c|c|c|c|}
\hline 1. & $\begin{array}{l}\text { Greifel } \\
\text { György }\end{array}$ & $\begin{array}{l}\text { Magyar hon- } \\
\text { polgár, } \\
\text { Kun Szent } \\
\text { Márton, } \\
\text { 1864. junius } \\
15 .\end{array}$ & $\begin{array}{l}\text { Az A \% alatti vég bi- } \\
\text { zonyítvány szerint a } \\
\text { budapesti egyetemen a } \\
\text { bölcsészeti } 4 \text { évi tanfo- } \\
\text { lyamot az } 1889 / 90 \text {-ik } \\
\text { tanévben befejezte. A } \\
\text { classica- philologiai } \\
\text { tanfolyamot hallgatta. }\end{array}$ & $\begin{array}{l}\text { Közkönyvtárnál } \\
\text { nem volt alkal- } \\
\text { mazva. }\end{array}$ & $\begin{array}{l}\text { A classica- } \\
\text { philologiai isme- } \\
\text { rete az A \% alatti } \\
\text { és a B\% alatti } \\
\text { mellékletben } \\
\text { igazoltatik. }\end{array}$ & Nincsen & $\begin{array}{l}\text { A B \% alatti melléklet } \\
\text { szerint jelenleg a Feke- } \\
\text { te József-féle nyilvános } \\
\text { gymnáziumba rendes } \\
\text { tanári minőségbe van } \\
\text { alkalmazva. A katonai } \\
\text { kötelezettséget túlhala- } \\
\text { dó korban van. } \\
\end{array}$ \\
\hline 2. & $\begin{array}{l}\text { Kováts } \\
\text { László }\end{array}$ & $\begin{array}{l}\text { Magyar hon- } \\
\text { polgár } \\
\text { Polgárdi, Fe- } \\
\text { hérmegye } \\
1871 . \text { nov. } \\
5 \text {-én. }\end{array}$ & $\begin{array}{l}\text { Mellékel } 2 \text { db. leczke- } \\
\text { könyvet, melylyel iga- } \\
\text { zolja, hogy a budapesti } \\
\text { egyetemen eleinte a } \\
\text { jog és államtud. kar, } \\
\text { később a bölcsészet } \\
\text { tudom. kar rendes } \\
\text { hallgatója volt, de az } \\
\text { egyetemi végzettséget } \\
\text { nem tudja igazolni. }\end{array}$ & $\begin{array}{l}\text { A „M.N. } \\
\text { Muzeum” könyv- } \\
\text { táránál napidíjas } \\
\text { minőségben } \\
\text { szolgál 1897. } \\
\text { márczius 1-től } \\
\text { kezdve maig az } \\
\text { igazgató őrnek } \\
\text { mellékelt bizo- } \\
\text { nyítványa szerint. }\end{array}$ & $\begin{array}{l}\text { A classica- } \\
\text { philologiai isme- } \\
\text { retét a mellékelt } \\
\text { leczkekönyvvel } \\
\text { igazolja. }\end{array}$ & $\begin{array}{l}\text { Irodalmi } \\
\text { munkássága } \\
\text { jeléül } 3 \mathrm{db} \\
\text { füzetet mellé- } \\
\text { kel a „Pallas- } \\
\text { lexikon”-ból. }\end{array}$ & $\begin{array}{l}\text { Katonai kötelezettségé- } \\
\text { nek eleget tett a mellé- } \\
\text { kelt katonai könyvecske } \\
\text { szerint. Az egyetemi } \\
\text { szabályszerü végzettsé- } \\
\text { get nem tudja beigazol- } \\
\text { ni. A pályázati vizsgától } \\
\text { 1898. febr. 5-én vissza- } \\
\text { lépett. }\end{array}$ \\
\hline 3. & $\begin{array}{l}\text { Steiner } \\
\text { Károly }\end{array}$ & $\begin{array}{l}\text { Magyar honos- } \\
\text { ságát, továbbá } \\
\text { születési idejét } \\
\text { és helyét nem } \\
\text { igazolja, folya- } \\
\text { modványában } \\
\text { azt állítja, hogy } \\
68 \text { éves. }\end{array}$ & $\begin{array}{l}\text { Tanulmányaira nézve } \\
\text { semmi bizonyítványt } \\
\text { nem mellékel. }\end{array}$ & $\begin{array}{l}\text { Közkönyvtárnál } \\
\text { nem volt és nin- } \\
\text { csen alkalmazva. }\end{array}$ & & & $\begin{array}{l}\text { Egyetemi végzettséget } \\
\text { nem tud igazolni. Ennél- } \\
\text { fogva a leglényegesebb } \\
\text { pályázati feltételnek } \\
\text { nem tud megfelelni. Az } \\
\text { 1885. és az 1896-iki } \\
\text { ország kiállításon felü- } \\
\text { gyelői minőségben volt } \\
\text { alkalmazva. A pályá- } \\
\text { zattól 1898. jan.31-én } \\
\text { visszalépett. }\end{array}$ \\
\hline
\end{tabular}




\begin{tabular}{|c|c|c|c|c|c|c|c|}
\hline 4. & \begin{tabular}{|l} 
Tetzel \\
Lörincz
\end{tabular} & $\begin{array}{l}\text { Magyar hon- } \\
\text { polgár } \\
\text { Rajka (Moson- } \\
\text { megye) } \\
\text { 1872. szept.14. }\end{array}$ & $\begin{array}{l}\text { A mellékelt végbizo- } \\
\text { nyítvány szerint az } \\
1896 / 7 \text { tanévben a bu- } \\
\text { dapesti egyetemen az } \\
\text { egyetemi tanulmányait } \\
\text { szabályszerűn befe- } \\
\text { jezte. Itt egy jogtudori } \\
\text { szigorlatot is tett le. }\end{array}$ & $\begin{array}{l}\text { A budapesti } \\
\text { egyetemi könyv- } \\
\text { tárnál 1893. decz. } \\
\text { 1. óta napidíjas } \\
\text { gyakornoki minő- } \\
\text { ségben megsza- } \\
\text { kítás nélkül volt } \\
\text { és van jelenleg is } \\
\text { alkalmazva. }\end{array}$ & $\begin{array}{l}\text { A mellékelt } \\
\text { bizonyítvány } \\
\text { szerint: a } \\
\text { magyar és német } \\
\text { nyelvben szó és } \\
\text { irásbelileg teljes } \\
\text { ismerettel bír, } \\
\text { ezen kívül az } \\
\text { ókori, classicai } \\
\text { (görög, latin) } \\
\text { és a franczia } \\
\text { nyelvben jártas. }\end{array}$ & & $\begin{array}{l}\text { Hadmentes. A Re- } \\
\text { mington-féle gépke- } \\
\text { zelésben jártas, a mi a } \\
\text { czédulázásnál nagyon } \\
\text { elönyös. A folyamodók } \\
\text { között az 1897. XXI t. } \\
\text { az 2. §-ének 2. pontja } \\
\text { alapján kezelőtiszti állás } \\
\text { betöltésénél elsőbbség- } \\
\text { gel bír. }\end{array}$ \\
\hline 5. & $\begin{array}{l}\text { Turchányi } \\
\text { Tihamér }\end{array}$ & & & & & $\begin{array}{l}\text { Irodalmi mun- } \\
\text { kássága jeléül } \\
\text { „Tabellae } \\
\text { chronographi- } \\
\text { cae” czímü } \\
\text { müvét mellé- } \\
\text { keli. }\end{array}$ & $\begin{array}{l}\text { Folyamodványában } \\
\text { semmivel sem igazolja, } \\
\text { hogy a pályázati } \\
\text { feltételeknek megtudna } \\
\text { felelni. A pályázati } \\
\text { vizsgán nem jelent meg. }\end{array}$ \\
\hline
\end{tabular}

1. táblázat. Az 1897. február 5-én tartott kezelőtiszti vizsgára jelentkezők előzetes minősítése 
„A vizsgálat eredményeit a bizottság kellő megfontolás tárgyává tévén, kimondja, hogy mindkét pályázó megfelelne ugyan a kezelötiszti állás feltételeinek, de a vizsgálat eredményéböl inkább Tetzel Lörincz mindenessen elsösége tünik ki, akinek különösen gyakorlati jártassága nagyobb, s így elsö helyen öt tatja ajánlhatónak. "A feleletek alapján tehát Tetzel bizonyult jobbnak, aki nem mellesleg 1893 óta napidíjas gyakornokként dolgozott az Egyetemi Könyvtárban, így megkapta az állást.

A könyvtárkezelésre vonatkozó kérdésekböl ugyancsak leszürhető, hogy könyvtári helyismeret nélkül nehezen elképzelhető a sikeres vizsga. Fontosnak tartották, hogy Tetzel a Remington-féle gépkezelésben jártas, amely a cédulázásnál nagyon előnyös. Ez abból is kiviláglik, hogy 1897. június 20-án felterjesztés ${ }^{25}$ született a Vallás- és Közoktatásügyi Minisztériumhoz az éves költségvetés terhére egy Remington-féle írógép beszerzése érdekében. „A czédulakatalógusnál a czímcéldulák másolásával kipróbáltam egy Remington-féle irógépet, s nagyon alkalmazhatónak találtam." - írja a könyvtárigazgató a miniszternek. A fenntartói engedély 1897. július 6-án meg is érkezett.

Tetzel Lőrinc 1914-től első őri kinevezést kapott, majd 1925-1926 között, másfél éven át a könyvtár vezetőjeként is dolgozott. A sors fintora, hogy mivel nem őt, hanem Pasteiner Ivánt nevezték ki később föigazgatónak, ezért feltételezések szerint öngyilkos lett. ${ }^{26}$

\section{„Az Egyetemi Könyvtár által taposott nyomokon továbbhaladva"27}

A XVI. század második felétől - több mint 450 éve - szisztematikusan gyarapított és folyamatosan müködő Egyetemi Könyvtár másfél milliós állományával a nemzeti kulturális örökség része, de nemzetközileg is ismert és elismert. A számos világritkaságot (közülük 185 kódexet - ebböl 14 korvinát -, illetve 1200 ősnyomtatványt, 11000 antikvát, 16500 barokk kötetet és 75000 XVIII. századi könyvet) örző gyüjtemény nemzetgazdasági szempontból is kiemelt jelentőségü, fokozottan védendő. Az ország első nyilvános könyvtárpalotája ugyanígy az egyetem büszkesége, az eredetileg

${ }^{25}$ Felterjesztés a magyar vallás- és közokt. m. kir. ministeriumhoz a könyvtári átalány terhére egy Remington-féle irógép beszerzése ügyében. 1897. június 20. ELTE Egyetemi Levéltár 19/a, 1898/226.

${ }^{26}$ Főigazgatóink a könyvtár állami intézménnyé válásától. Forrás: http://www.[-] konyvtar.elte.hu/regi/magunkrol/tortenet/foigok.html [2016. 01. 18.]

${ }^{27}$ V. Windisch Éva: i. m. 152. p. 
is könyvtár céljára emelt müemléképület nemzetközi viszonylatban is kuriózumnak számít.

A gyüjtemény és az infrastruktúra mellett, napjaink divatos kifejezésével élve, a humánerőforrás-fejlesztésre térve jogosan hangsúlyozhatjuk azt is, hogy - az egyetemi könyvtári álláshelyek betöltése nyomán, illetve az elöléptetések hatására - a hazai könyvtári szakképesités kialakulása tudományegyetemünkhöz kötődik, rendszerének fejlődése innen eredeztethetö. Az is kétségtelen, hogy mindaddig mintául szolgált a többi bibliotéka számára, míg az egyetemi intézményes könyvtárosképzés ugyancsak a mostani ELTE berkeiben megszerveződött, s vált a könyvtártudományi stúdiumok vezető hazai mühelyévé. Közleményünk - primer forrásokon nyugvó - szemelvényei a könyvtárosi pálya magyarországi létrejöttének fontos lenyomatai, melyek a XXI. században is termékeny hatással bírnak munkánkra. ${ }^{28}$

A szerzö köszönetet mond Patkósné Tóth Zsuzsanna könyvtárosnak (ELTE BTK Könyvtár- és Információtudományi Intézet), valamint Székely Hunor levéltárosnak (ELTE Egyetemi Levéltár) a tanulmány elkészitéséhez nyújtott nélkülözhetetlen segitségükért.

\section{Rezümé}

1945 elött nem folyt rendszeres könyvtárosképzés Magyarországon. Néhány nagykönyvtár, valamint a Magyar Könyvtárosok és Levéltárosok Egyesülete alkalmi tanfolyamokat szervezett. Az egyetemi képzésben is szerepeltek könyvtári szaktárgyak (ezeket magántanárok tanították), de önálló könyvtártanszékkel egészen 1949-ig nem rendelkezett a hazai könyvtáros szakma. Az ismeretek elsajátítására csak szük körnek volt lehetősége. Az első hazai könyvtáros-szakvizsgára 1874-ben az ELTE Egyetemi Könyvtár jogelődjében került sor. A tanulmány levéltári források felhasználásával ezt az úttörö és az 1897/98. évi könyvtárosi pályázatot ismerteti, bemutatja a jelölteket, s leírja a szakvizsga folyamatát.

${ }^{28}$ Az ELTE Egyetemi Könyvtárának, valamint a Bölcsészettudományi Kar Könyvtár- és Információtudományi Intézetének jelenleg is zajló, az elmélet és a gyakorlat összhangját célzó szakmai együttmüködését, illetve annak koncepcionális modelljét ismerteti: Kiszl Péter: Könyvtártudomány elméletben és gyakorlatban - intézményi együttmüködés az Eötvös Loránd Tudományegyetemen. = Tudományos és Müszaki Tájékoztatás, 61. évf. 2014. 7-8. sz. 251-266. p. 


\section{"A lot more inclination and learning is desired than in the case of other professions"}

The role of the University Library in the development of the first national qualifying exam for librarians

Before 1945 there was no regular training for librarians in Hungary, only some large libraries and the Association of Librarians and Archivists organized ad hoc courses. University trainings also included library subjects (taught by private lecturers), but the library profession did not have a separate library department at any university until 1949. It was only a narrow circle of librarians who had the opportunity to acquire professional knowledge. The first qualifying exam for librarians took place in 1874, in the predecessor institution of ELTE University Library. Using archival sources, the study describes this pioneering event and the 1897/98 job advertisement, presents the candidates, and the examination procedure.

KISZL PÉTER intézetigazgató

ELTE BTK Könyvtár- és Információtudományi Intézet 


\section{Miként kaptak jelzetet az ELTE Egyetemi Könyvtár corvinái?*}

Ismeretes, hogy az ELTE Egyetemi Könyvtár állományának legjelentősebb bővülése szoros kapcsolatban áll Mária Terézia jezsuita rendet és II. József szerzetesrendeket feloszlató rendelkezéseivel. A XVIII. századi abolíciós intézkedéseket követően összesen mintegy 450 új kézirat, köztük 66 középkori kódex került az ekkor már államosított egyetem könyvtárába. Ehhez az állománygyarapodáshoz mérhetö újabb, minőségi bővülés 1877-ben volt. Ekkor - mint ismeretes - II. Abdülhamid török szultán 35 kódexet, a török fél véleménye szerint kivétel nélkül Magyarországról egykor hadizsákmányként „elhurcolt” corvinákat, ajándékozott a budapesti egyetemistáknak, s ezek örzőhelye az egyetem könyvtára lett. ${ }^{1}$ Miután a „törökországi” kódexeket 1877-ben rövid idöre nyilvános kiállításon mutatták be a Magyar Nemzeti Múzeumban, átszállították a könyvtárba. A könyvészeti kutatás nagyra értékelte és fokozott figyelemmel kísérte a kódexek Magyarországra kerülését, „könyvtáraink és könyvészetünk történetének egyik legörvendetesebb eseményeként" értékelte. ${ }^{2}$

A kódexeket a XIX. század második feli magyarországi tudományos élet több jeles szakértője vizsgálta meg, kutathatóságukhoz elengedhe-

* A dolgozat elkészítésére több körülmény ösztönzött. Ezek közül az egyik, hogy az Egyetemi Könyvtárban őrzött kódexek kutatása még közel sem nem fejeződött be, esetleges „újabb” corvinák „felismerése” feltételesen még várható. Vö. pl. Mikó Árpád, Az Egyetemi Könyvtár Dante-kódexének (Cod. Ital. 1.) eredeti kötéséről. Henszlmann Imre kiadatlan feljegyzése. $=$ Művészettörténeti Értesítő, 63. évf. (2014.) 2. sz. 397-399. p. Másrészt a legutóbbi időkig még szakkutatók is eltévesztik, melyek az Egyetemi Könyvtárban őrzött corvinák jelzetei. Vö. pl. Madas Edit: A Corvina újkori története Magyarországon. = A holló jegyében. Fejezetek a Corvinák történetéből. Szerk. Monok István. Budapest, Corvina Kiadó - OSzK, 2004, 64-81. p., itt: 75, 25. jegyzet - e jegyzet szerint az Egyetemi Könyvtárban a corvinák jelzetei „Cod. Lat. 1-től 14-ig”. De a jelzetsor nem ez! A corvinák jelzetei a könyvtárban: Cod. Lat. 1-13, 31.

${ }^{1}$ Knapp Éva: A,,törökországi” kódexek a budapesti Egyetemi Könyvtárban. = Erödi Béla: Csok Jasa! A török küldöttség látogatásának emlékkönyve. Budapest, Akadémiai Kiadó - Magyar-Török Baráti Társaság. 2001. 119-132. p.

${ }^{2}$ Vö. pl. A Corvinák. = Magyar Könyvszemle, 2. évf. 1877. 2. sz. Vegyes Közlemények, 141. p. 
tetlenül hozzátartozott könyvészeti számbavételük és leírásuk. Ennek elkészítéséhez a francia nyelven készült, török záradékkal ellátott eredeti átadási jegyzőkönyv (Catalogue de la Corviniana) - amit nagy becsben tart és őriz az ELTE Egyetemi Könyvtár (a J 256 jelzeten) - mindössze szerény alapot jelentett. Ebbe a jegyzőkönyvbe ugyanis csupán a kódexek azonosításához szükséges minimális adatok kerültek bele, így a szerzők neve rövid névalakban (például „Nr. 14. Cicero”; vagy „Nr. 24. Tacitus”), a kézirat tartalmának megjelölése (például „Nr. 28. Livre religieux”), esetleg a szerző és a mü együttes megnevezése (például „Nr. 30. Dante, comedia divina”; vagy „Nr. 35. Cicero in Verrem”). A kódexekhez rendelt, minden bizonnyal esetleges átadási sorszám a könyvészeti feldolgozás során megváltozott.

A katalogizálás feladatát elsőként Csontosi János végezte el 1877-ben. A Magyar Könyvszemlében megjelent, bőséges megjegyzésekkel kísért bibliográfia önálló kiadványként, mint különnyomat is hozzáférhetővé vált $A$ Konstantinápolyból érkezett Corvinák bibliographiai ismertetése címen. A kódexek „mütörténeti” leírásában Pulszky Károly nyújtott segítséget. Csontosi a 35 kódex corvina-jellegét - amint azt tanulmányának címe is jelzi - nem kérdőjelezte meg, viszont a kéziratokat három részre osztotta. A felosztás határozottan utal arra, hogy a szakemberek már 1877-ben felismerték, hogy a kódexeknek valószínüleg csupán egy része származhat Hunyadi Mátyás híres könyvtárából. Csontosi szerint az első csoportba tartoznak a „kétségtelen Corvinák, melyek Mátyás király egyenes megrendelésére írattak és a czímlapon az ő czímerét viselik", a másodikba azok, melyeknél a „kiállítási jelleg vagy egyéb körülmény valószínűvé teszik, hogy Mátyás király könyvtárából származnak", végül a harmadikba azok, ,melyek a corvinák characteristiconját nem bírják, a mi azonban nem zárja ki azt, hogy [...] Mátyás király könyvtárába kerültek, vagy a régi magyar királyi könyvtár alkatrészeit képezhették". Csontosit követően, öt részben kiegészítve, Török Árpád XXXV Handschriften. Geschenk des Sultans Abdul Hamid II. (Budapest, Martin Bagó, 1878) címen német nyelven írt a kéziratokról. Csontosi külön utalt a kódexek átköttetésére, a kéziratokba arany festékkel bejegyzett ajándékozási szövegre és a kötetekben fellelhető korábbi könyvtári örzésre utaló jelzetekre török, francia és latin nyelven, valamint arra, hogy csupán a „harmadik csoportba sorozott kéziratokat vágták újra körül”. 
A Csontosi-féle „kétségtelen” tíz corvinán (Cod. Lat. 1-10) kívül további négy „,valószínü” corvinát tekint ma a kutatás - Csapodi Csaba Csapodiné Gárdonyi Klára Bibliotheca Corviniánája (Budapest, 1990) alapján - hiteles corvinának. A négy utóbbiból hiányzik az első levél, így címer sincs ezekben. Ezek a kódexek a következő jellegzetességek miatt corvinák. A Cod. Lat. 11-et jellegzetes, színes festéssel díszített budai aranymetszése (arany alapon zöld, fehér, vörös és kék virágdíszek között a kötet kapitális betüs címe, COMMENTARIACESARIS), a Cod. Lat. 13-at „1487. 17. Augusti In dicionem Regis Mathie per longam obsidionem tandem venit Vyhel imperialis Austrie" bejegyzése miatt tekinti a kutatás corvinának. A Cod. Lat. 13 idézett bejegyzésének készítője magyar személy lehetett, amint erről Bécsújhely magyar névalakja tanúskodik. A Cod. Lat. 12 és 31 jelzetü kódexeket az emendáló, Vitéz János bejegyzései miatt sorolták a Bibliotheca Corviniana állományához.

A „törökországi” kódexek katalogizálása a könyvtár többi kódexének könyvészeti leírásával együtt készült el, mivel 1877 előtt behatóan csak a nyolc magyar nyelvemlék-kódexszel foglalkoztak, szövegkiadás is ezekröl készült. Az 1881-ben napvilágot látott katalógusban (A budapesti M. Kir. Egyetemi Könyvtár codexeinek czímjegyzéke - Catalogus Codicum Bibliothecae Universitatis R. Scientiarum Budapestinensis) a „törökországi” kódexek („Codices a Turcarum imperatore dono dati”) - nyelvüktől függetlenül - kapták meg a Cod. 1-35 jelzetet. Ez a szignatúra rend az 1961-ben megjelent, Mezey László által készített latin kódexkatalógusban (Codices Latini Medii Aevi Bibliothecae Universitatis Budapestinensis, Budapest, Akadémiai Kiadó, 1961) megváltozott. A „törökországi” kódexek közül az első 32 tétel megtartotta korábbi jelzetét (1881), míg a Cod. 33, 34, 35 jelzésü kódexeket - a kéziratok nyelvének figyelembe vételével - a Cod. Ital. 1, 2, 3 jelzettel látták el, s a 33, 34, 35-ös számot a latin kódexek jelzésére használták fel. Azaz a corvina kódexek jelzete változatlan maradt.

A könyvtár corvinái között a Csontosi-féle „kétségtelenül” hiteles tíz corvina a Cod. Lat. 1-10 jelzetet viseli. Ezek közül több kódex olyan tartalmi és formai jegyeket hordoz, melyek egyedülállóak a ma ismert corvinák között. E sajátosságok mérlegelésével kapták meg egykorúan ezek a kéziratok jelzeteiket. Így például a Cod. Lat. 1 jelzeten örzött Theophrastus-kódex az egyetlen olyan corvina, melyben a scriptor feltüntette, hogy a kódex Firenzében Vespasiano mühelyében készült („Vespasianus librarius florentinus fieri fecit florentiae"). A Cod. Lat. 2-10 ilyen egyértelmü kü- 
lönlegességet nem tartalmaz, ezért ezek a szerzők, illetve a címek alapján betürendbe sorolva kaptak jelzetet.

\begin{tabular}{|l|l|}
\hline Cod. Lat. 2 & Cicero, Marcus Tullius \\
Cod. Lat. 3 & [Pseudo-] Clemes Romanus \\
Cod. Lat. 4 & Curtius Rufus, Quintus \\
Cod. Lat. 5 & Eusebius [Caesariensis] Pamphili \\
Cod. Lat. 6 & Eusebius [Caesariensis] Pamphili \\
Cod. Lat. 7 & Scriptores Historiae Augustae \\
Cod. Lat. 8 & Silius Italicus \\
Cod. Lat. 9 & Tacitus, Publius Cornelius \\
Cod. Lat. 10 & Tertullianus, Quintus Septimius Florens \\
\hline
\end{tabular}

Ugyanakkor az úgynevezett hiteles corvinák szinte mindegyike őriz valami egyéb sajátosságot is. Így a Cod. Lat. 1-, 2-, 3-, 5-, 6-, 7-, 8-, 9-, 10nek színes festéssel díszített budai aranymetszése van. A Cod. Lat. 3 ezen felül tartalmaz egy olyan lapot (fol. 2v), melynek miniálását utólag készítették Budán. Két hiteles corvina eredetileg Vitéz János könyvtárához tartozhatott, mivel ezekben a szövegjavítások tőle származnak (Cod. Lat. 3, 10). Egy kötet Beatrix királyné könyvtárával érkezhetett Budára (Cod. Lat. 4), ezt a Mátyás királyéval nem egyesített címer jelzi. Berkovits Ilona állapította meg (A magyarországi corvinák, Budapest, 1962, 113-115.), hogy a Cod. Lat. 1, 2, 3, 5, 6, 7, 8, 10 Firenzében, a Cod. Lat. 4, 9 Nápolyban készült. Ezek a felsorolt sajátosságok azonban nem váltak jelzetkiadást befolyásoló elemmé.

Az a további négy corvina, melyekből hiányzik az első levél, és így címer sincs bennük, a következő sorrendben kaptak jelzetet. A jellegzetes, színes festéssel díszített budai aranymetszés miatt a Cod. Lat. 11-es jelzetet kapta a Caius Iulius Caesar által írt, saját hadjáratait megörökítő müvek együttese. A Cod. Lat. 12-öt Vitéz János javította, míg a Cod. Lat. 13 Bécsújhely Mátyás király általi elfoglalását tartalmazó bejegyzése miatt kapta a sorrendben következő szignatúrát. A Cod. Lat. 31 jelzetü kódexben a „törökországi” kódexek jelzeteinek kiadása után azonosították az emendáló, Vitéz János bejegyzéseit, s ekkor már nem változtatták meg a jelzet-rendet. 
A kutatás azóta sem ért véget. ${ }^{3}$ Mikó Árpád 2014-ben publikálta Henszlmann Imre Isztambulban készített kiadatlan feljegyzéseit a Dantekódex eredeti kötéséről. E feljegyzéshez egy rajz is tartozik, mely szerint a kódex kötése egy jellegzetes magyarországi kötéstípushoz tartozott, mely valószínüsíti, hogy a kódexet a XV. században Magyarországon örizték - esetleg a királyi könyvtárban lehetett az örzési helye. Azaz a további forrásvizsgálatok - esetleg - lehetővé teszik a könyvtár corvináinak további bővülését is.

\section{Rezümé}

A dolgozat elkészítésére több körülmény ösztönzött. Ezek közül az egyik, hogy az Egyetemi Könyvtárban őrzött kódexek kutatása még közel sem fejeződött be, esetleges „újabb” corvinák „felismerése” feltételesen még várható. Másrészt a legutóbbi időkig még szakkutatók is eltévesztik, melyek az Egyetemi Könyvtárban őrzött corvinák jelzetei. A tanulmány a kutatás jelenlegi helyzete mellett összefoglalja a jelzetadás történetére vonatkozó ismereteket.

\section{How did the 'Corvinae' of the University Library get shelf marks?}

Writing this study was motivated by several circumstances. One of them is that the research of codices treasured in the University Library is still in progress, and discovering any "new" corvina may be expected. On the other hand, until recently even professional researchers miss the notations of the corvinas treasured in the University Library. This study not only summarizes the current state of the research but also the knowledge of number building history.

KNAPP ÉVA tudományos ügyek referense ELTE Egyetemi Könyvtár

${ }^{3}$ Mikó Árpád: Az Egyetemi Könyvtár Dante-kódexének (Cod. Ital. 1.) eredeti kötéséröl. Henszlmann Imre kiadatlan feljegyzése. = Mủvészettörténeti Értesítő, 63. évf. 2014. 2. sz. 397-399. p. 



\section{Könyvtárhasználók igényeire szabott szolgáltatásfejlesztés az Egyetemi Könyvtárban}

\section{Az elözmények}

Az Egyetemi Könyvtári Szolgálat (továbbiakban EKSz) K21 minőségfejlesztési projektje rendszeres időközönként végez olvasói és oktatói igényfelméréseket, elégedettségméréseket. Emellett az Egyetemi Könyvtár saját projektjeihez kapcsolódva is végzett hasonló felméréseket, melyek részben a könyvtár szolgáltatásaira kérdeztek rá.

A kérdésekre adott válaszok egy része egyértelmúen rámutatott arra, hogy szükség van a hagyományos dokumentumkikérés folyamatának változtatására, és ezt megerősítették a napi könyvtárhasználatban az olvasók visszajelzései és a könyvtárosok tapasztalatai is.

\section{A hagyományos dokumentumkikérés}

Az Egyetemi Könyvtár állományának viszonylag nagy, 90\% feletti része zárt raktárakban található, ahová az olvasó nem mehet be. A dokumentumok kikérése ezekből a raktárakból kizárólag papíralapú kérőlap kitöltésével lehetséges. Attól függően, hogy kölcsönzésre vagy helyben olvasásra kéri ki valaki a példányokat, más-más kérőlapot kell kitölteni, amelyekre fel kell vinni a dokumentum egyes adatait. Ezek az adatok eltérök lehetnek bizonyos dokumentumtípusok esetén, például más adatot kell ráírni könyv, kézirat vagy időszaki kiadvány esetén. Amit minden dokumentumnál szükséges megadni, az a jelzet, mely a dokumentum egyedi azonosítója.

A hagyományos dokumentumkikérés lépéseinek vázlata:

- a dokumentumhoz tartozó adatok (például szerző, cím, kiadási év, évfolyam, dátum + jelzet kikeresése a könyvtár elektronikus (web-OPAC), illetve valamely papír katalógusából;

- a papíralapú kérőlap(ok) kitöltése önállóan vagy könyvtáros segítségét igénybe véve;

- kérőlap(ok) raktárba juttatása könyvtáros vagy raktáros által.

A kérölap kitöltése gyakran könyvtáros segítséggel valósul meg az olvasók telefonon bediktált, vagy e-mailben elküldött információi alapján. 
A felmérésekre adott használói visszajelzések egybecsengtek a könyvtárosok észrevételeivel: mivel a Könyvtárhasználati Szabályzatban foglaltak szerint egy olvasónak, olvasói státusztól függően, lehetősége van akár 20-30 dokumentumot is kikérni, ezért a telefonos megkeresések, $\mathrm{s}$ az ezek következtében a könyvtárosra háruló adminisztráció jelentősen lassítja a kiszolgálást. Emellett az is sokszor előfordul a közönségszolgálatban, hogy csak egyedül teljesít szolgálatot valamely kolléga, minden további felmerülő helyzet megoldásáért is felelve. Szükséges tehát a munkafolyamatok optimalizálása.

\section{A fejlesztés 1. szakasza}

A beérkezett visszajelzések alapján felülvizsgálatra került a hagyományos dokumentumkikérés folyamata, ezzel együtt kialakítottuk az elektronikus ügyintézés tervezett lépéseit is. Meghatároztuk, hogy a fejlesztésnek mind az angol, mind a magyar felületen párhuzamosan kell haladnia a web-OPAC-on, és azt is, hogy minden lépést több böngészőből indulva is ellenőrizni kell, hogy a felhasználók megfelelő tartalmat és megjelenítést lássanak.

Az elektronikus dokumentumkikérés tervezett lépései:

- beiratkozás - azonosító rendelése az olvasó nevéhez,

- bejelentkezés a web-OPAC katalógusba,

- dokumentumkeresés a web-OPAC katalógusban,

- dokumentum kiválasztása,

- dokumentum kikérése online,

- a kérölap nyomtatása az 1 . és a 4. emeleten elhelyezett nyomtatók valamelyikén.

\section{A fejlesztés 2. szakasza}

A hagyományos dokumentumkikérés folyamatának vizsgálata, a fejlesztendő, nem hatékony pontok megjelölése, valamint az elektronikus dokumentumkikérés tervezett lépéseinek meghatározásával egy időben történt meg az erőforrások felmérése. Személyi, eszköz és anyagi oldalról vizsgáltuk meg a rendelkezésre álló forrásokat.

Látogatást tettünk az Aleph IKR magyarországi forgalmazójánál, az Ex-Lh Számítástechnikai Kft.-nél. Velük több megbeszélésen vettünk részt, ahol tájékoztatást kaptunk a rendszer nyújtotta lehetőségekről, a működésről és az árakról. 
Figyelembe véve az igényeinket, az erőforrásainkat és a rendszer adta lehetőségeket, többszöri egyeztetés után hoztuk meg a döntést arról, hogy melyik verziót választjuk ki és alakítjuk tovább.

A jó gyakorlatok átvétele okán látogatást tettünk két olyan könyvtárban, ahol már müködik az elektronikus dokumentumkikérés. Először a BME OMIKK-ba, majd az Országgyülési Könyvtárba mentünk el, mindkét könyvtárban Aleph-rendszert használnak, ugyanaz a fejlesztő csoport segíti őket. Az Országgyülési Könyvtárban nemcsak olvasói oldalról, hanem informatikai oldalról is meg tudtuk nézni a kikérés müködését, menetét és a tapasztalatokat, javaslatokat is hallottuk.

\section{A fejlesztés 3. szakasza}

Az Aleph-beli módosítások első lépése az új gyüjtemények kialakítása volt. Ennek keretében a korábbi „U=EK raktár” gyüjteményt kellett a jelzettartományok pontos megadásával szétbontani úgy, hogy az egyes raktárszinteknek egy-egy gyüjtemény feleljen meg. Ennek oka az volt, hogy minden egyes dokumentum esetében meg kellett tudni mondani és be kellett állítani az Aleph-ben, hogy a hozzá tartozó kérőlap nyomtatása az első vagy a negyedik emeleti nyomtatón történjen. Így létrejöttek az „U1=EK raktár 1”, „U2=EK raktár 2”, „U3=EK raktár 3”, „,U4=EK raktár 4”, „U5=EK raktár 5”, „U6=EK raktár 6”, „U7=EK raktár 7”, „,U8=EK raktár 8”, „U9=EK raktár 9” és „U10=EK raktár 10” gyüjtemények. A gyüjtemények számozásakor figyelembe vettük azt is, hogy az egyes raktárszinteken belül is vannak újabb szintek, ezek mindegyike külön számot kapott.

A gyüjtemények kialakítása után történt az Aleph-en belül a példányok mozgatása az „U=EK raktár” gyüjteményböl a jelzetnek megfelelő új gyüjteménybe. Ennek végeztével az „U=EK raktár” gyűjtemény lezárásra került, abba új példányt felvenni nem lehet. Azon esetekben, amikor bármi probléma volt a jelzettel, például a jelzet hibás volt, a példányok maradtak az „U=EK raktár” gyüjteményben. Ilyenkor egyenként történt a javítás, majd ezt követően a gyüjteménybe mozgatás.

A gyüjtemények rendezése után megtörtént számítógépek és az idöközben beszerzett nyomtatók beállítása és paraméterezése a két raktárszinten. Ezzel párhuzamosan határoztuk meg a nyomtatott kérőlap adattartományát. A cél az volt, hogy mind olvasói, mind példány oldalról olyan adatok kerüljenek a kérőlapra, amelyek egyértelmüen azonosítják a kikérőt és a kért 
dokumentumot is, megadják a kikéréshez kapcsolódó időket és mutatják az átvételi helyet is. Ezek alapján a kérőlapra az alábbi adatok kerültek:

- szerzö,

- cím,

- jelzet,

- gyüjtemény,

- példánystátusz,

- kérés kezdete,

- kérés vége,

- kérés ideje,

- nyomtatás ideje,

- átvétel helye,

- olvasó neve,

- olvasó azonosítója,

- olvasó vonalkódja.

Az adatok meghatározása után történt a kérölap méretezése és a nyomtatási beállítások megadása. Az adatok sorrendjét úgy jelöltük ki, hogy azok elrendezése a kérőlapon optimális legyen. Abban az esetben, ha az adott sorhoz nem tartozik adat (például szerző), akkor az a kategória nem kerül rá a kérőlapra.

Az Aleph-ben történt meg a jogosultságok beállítása is. Olvasói státusz oldalról mindenkinek engedtük az elektronikus dokumentumkikérést. Itt egységesen adtuk meg a kikérhető dokumentumok számát, amit lehetőség van emelni, illetve csökkenteni olvasói státuszonként vagy együttesen is.

Példánystátusz és a gyüjtemények esetében volt olyan, ahol engedtük (például 21 = kölcsönözhető példánystátusz; U3 gyüjtemény), és volt olyan, ahol tiltottuk a kikérést (például 62 = periodika leltár példány; $\mathrm{SINF}=$ Segédkönyvtár Informatika). Azon példányok esetében, amelyek a példánystátusz mellett rendelkeztek feldolgozási státusszal is, minden esetben tiltottuk a kikérést.

Az elektronikus dokumentumkikérés során beérkezett kéréseket az Aleph-ben beállított szerviz hívja le. A lekérdezés gyakoriságát 1 percben határoztuk meg. Ennek alapján a lefutó szerviz percenként vizsgálja, hogy érkezett-e kérés az adott időszakban. Ha igen, akkor ez(eke)t a két nyomtató valamelyikére küldi. 


\section{A fejlesztés 4. szakasza}

Ebben a szakaszban történt meg az elektronikus dokumentumkikérés ürlapjának kialakítása. A korábban tervezett lépéseket nézve a bejelentkezés után, a dokumentum kikeresése, majd kiválasztás után az engedélyezett esetekben a példánynál jelenik meg a „kikérés” felirat. Az olvasó erre kattintva tudja kikérni az adott példányt a felugró ürlapon.

Az ürlap kialakításakor törekedtünk arra, hogy:

- csak olyan adatok legyenek rajta, amelyek a kikérésnél fontosak,

- az ürlap legyen átlátható,

- az olvasónak minél kevesebb adatot kelljen saját magának beírnia,

- amit lehet, automatizáljunk.

Ennek megfelelően az alábbi ürlapot alakítottuk ki:

Elôjegyzés, kikérés - Czinki-Vietorisz Gabriella

(1) Ha kérdése van, irjon!

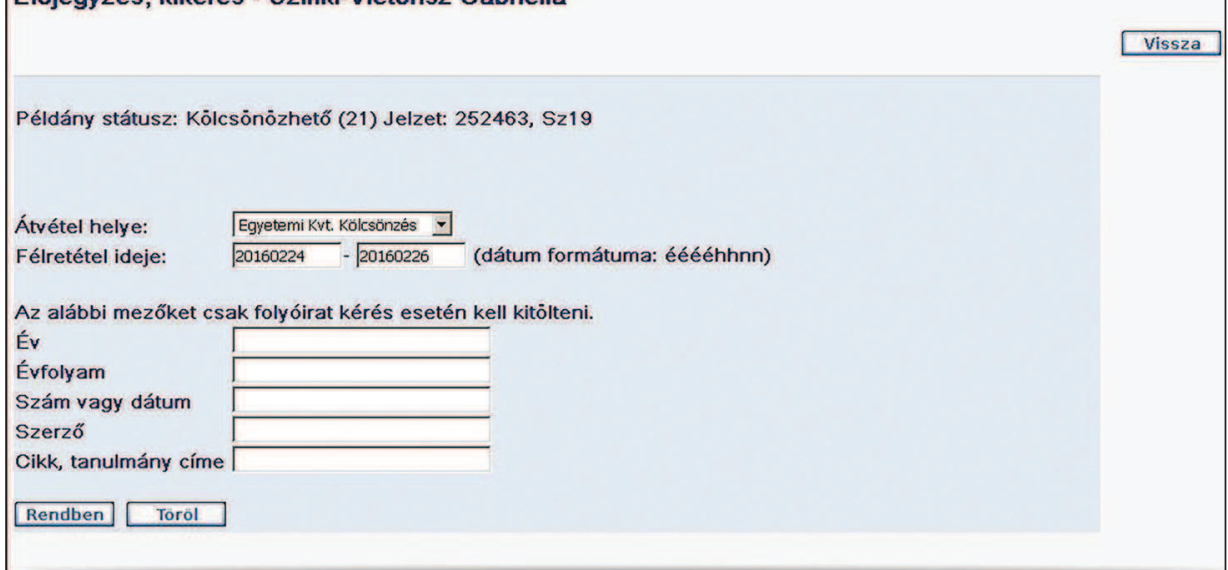

1. ábra. Képernyőkép ${ }^{1}$

Az ürlapon megtalálható a bejelentkezett olvasó neve, a kikért példány státusza (Kölcsönözhető, 21), a kiválasztott dokumentumhoz tartozó példányok jelzetei (254377, Sz19). Az „Átvétel helye” mezőben két lehetőség közül lehet választani: Egyetemi Könyvtár Kölcsönzés és Egyetemi Könyvtár Olvasóterem. Abban az esetben, ha az olvasó helyben használható példánystátuszú dokumentumot kér ki, az „Átvétel helye” automati-

${ }^{1}$ Elektronikus dokumentumkikérés ürlapja. Forrás: www.opac.elte.hu. [2016. 02. 25.] 
kusan az Egyetemi Könyvtár Olvasóterem lesz. Ha a példánystátusz ettől eltér, akkor lehet a két opció közül választani. A „Félretétel ideje” mező beállítása automatikus, a Könyvtárhasználati Szabályzatban foglaltak szerint első esetben 2, második esetben 10 nyitvatartási nap. Ha az olvasó nem időszaki kiadványt kér ki, akkor a „Rendben” gombra kattintással indítja a kérést, s az rögzül a nevénél.

Időszaki kiadvány esetében a kikérés menete kétféle lehet.

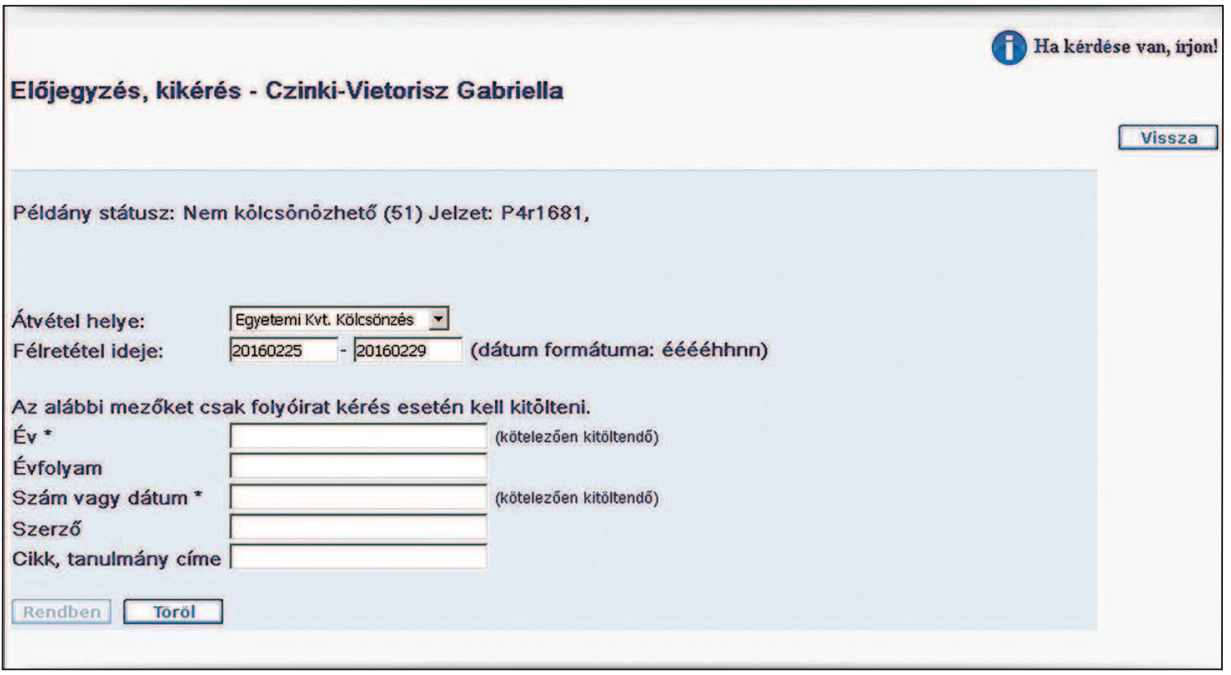

2. ábra. Képernyőkép ${ }^{2}$

Ha az olvasó olyan időszaki kiadványt kér ki, amelyben összevont adatok vannak, vagyis a példányhoz egy tól-ig-időszak tartozik (pl. 1. évf. 2000. - 15. évf. 2014.), akkor az ürlap második részében lévő mezők közül a kötelezőket ki kell töltenie. Ezeket a mezőket külön is megjelöltük * (csillaggal), és a sor végén zárójeles megjegyzés is utal a kitöltésre. Amíg az olvasó nem tölti ki ezeket a mezőket, addig az ürlap alján lévő „Rendben” gomb nem lesz aktív, így a kérés nem indítható a raktárba. Ha a mezők kitöltése megtörtént, akkor a „Rendben” gomb aktív lesz, így a kérés már rögzíthetö.

A másik lehetőség időszaki kiadvány esetében, ha a példányhoz tartozik egy évfolyam, egy év és egy szám. Ekkor a kötelező mezőkbe ezek

${ }^{2}$ Elektronikus dokumentumkikérés ürlapja. Forrás. www.opac.elte.hu. [2016. 02. 25.] 
az adatok automatikusan átemelődnek, és mivel helyben használható példányról van szó, az automatikus beállítások megtörténnek az „Átvétel helye” és a „Félretétel ideje” mezőkben, így az olvasónak a „Rendben” gomb megnyomásával lehetősége van a kérés indítására.

\section{A fejlesztés 5. szakasza}

Akár olvasói, akár példány oldalról előfordulhat, hogy a kikérésnek akadálya van. Ebben a szakaszban az ehhez kapcsolódó tájékoztató szövegeket készítettük el és állítottuk be a web-OPAC-ban. Az olvasó részéről akadály lehet a tagság lejárata, vagy az, hogy elérte az engedélyezett kikérések számát. Mindkét esetben megjelenik a tájékoztató felirat, mely a tényleges problémát vagy problémákat jelzi az olvasónak. Példány oldalról jeleztük azt, ha az egyes példányok olyan gyüjteményben vannak, amelyek nem raktáriak, hanem a polcról levehetők. Ide tartoznak a Folyóiratolvasó, az Olvasóterem és a Szabadpolc gyüjtemények.

A „Kötészeten”, „Kötésre előkészítve” és „Katalogizálás alatt” feldolgozási státuszú példányok esetében nem jelenik meg a kikérési lehetőség. Ez a státusz nem állandó státusza a példányoknak, de olyan munkákat jeleznek, amelyek ideje alatt a példány nem elérhető. Ha a nevezett munkák elkészültek, a dokumentumokról ez a státusz törlődik, és csak a példánystátusz marad. Az ilyen feldolgozási státuszú dokumentumoknál az olvasót a könyvtároshoz irányítjuk, aki az egyes nyilvántartásokból, illetve egyeztetések után meg tudja mondani, hogy a keresett mü mikor lesz elérhető.

Vannak olyan dokumentumok, amelyek külső raktárban találhatók. Ezek a Folyóirat külső raktár és az EK, külső raktár gyüjtemények példányai. Több tényező is befolyásolja, hogy ezeket mikor tudják az Egyetemi Könyvtárba beszállítani. Ilyen esetekben is helyeztünk el tájékoztatást, melyben az olvasót szintén a könyvtároshoz irányítjuk.

\section{Olvasói oldal, könyvtárosi oldal}

Az olvasó a web-OPAC-ban a bejelentkezés után az „Olvasójegyem” menüben a „Kikérések, előjegyzések” sorra kattintva tudja megnézni, hogy mely kikérések vannak a nevén. Lehetősége van törölni, ha a kikért példányra nincs szüksége a továbbiakban.

Könyvtárosi oldalról indulva az Aleph-ben az olvasó adatlapját megnyitva láthatók a kikérések. A könyvtárosnak lehetősége van törölni a ki- 
kérést, ha az olvasó ezt kéri tőle. A kölcsönzési müvelet automatikusan törli a kikérést az olvasó nevéröl. Ha a félretételi idő letelik, a törlés automatikusan megtörténik.

\section{A fejlesztés 6. szakasza}

Az olvasói tájékoztatás több formában valósult meg:

- az olvasók szöveges tájékoztatást kaptak,

- az elektronikus dokumentumkikérés tájékoztatóját megjelentettük az EKSz-portálon: http://konyvtar.elte.hu/hu/ekerolap,

- szóróanyagokat helyeztünk el a könyvtár szolgáltatási pontjain,

- az olvasóknak küldött e-mailekben helyeztük el a portálhír linkjét.

\section{Visszajelzések, statisztika}

Az olvasói visszajelzések folyamatosan érkeznek a könyvtárba. Ezek legnagyobb része pozitív, az olvasók elégedettek, jó fejlesztésnek tartják a szolgáltatást. 2015. januártól júliusig az összes raktári dokumentumkikérés $60 \%$-át kérték ki az olvasók elektronikus dokumentumkikéréssel.

Az e-mailes kérések száma folyamatosan csökkent:

- 2013. január-június: 1060 db dokumentum

- 2014. január-június: 914 db dokumentum (-14\%)

- 2015. január-június: 194 db dokumentum (-79\%)

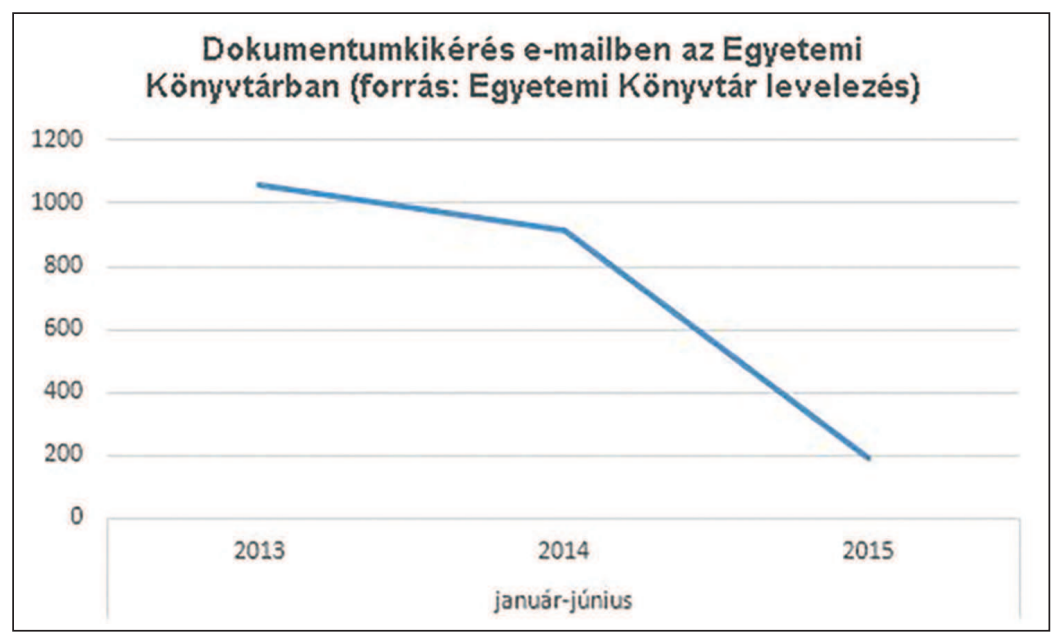

3. ábra. Dokumentumkikérés az Egyetemi Könyvtárban (az adatok forrása: Egyetemi Könyvtár - levelezés) 
Köszönet

Az egyéb munkáink mellett az elektronikus kérőlap bevezetésének folyamata a tervezéstől a tesztelésen át a megvalósításig nagyjából 1 évet ölelt fel. Köszönetemet fejezem ki alábbi kollégáimnak és a további közremüködöknek az elvégzett munkáért, amelynek segítségével a projektet sikeresen megvalósítottuk.

- Cerva Csaba - Egyetemi Könyvtár Informatikai és Fejlesztési Osztály: Aleph, hardver;

- Polán Attila - Tanító és Óvóképző Kar Kari Könyvtár: web-OPAC;

- Székelyné Török Tünde - Egyetemi Könyvtár Gyüjteményszervezési Osztály: szakmai tanácsadás;

- Szépvölgyi Katalin - Egyetemi Könyvtár Gyüjteményszervezési Osztály Folyóirat csoport: szakmai tanácsadás;

- Varga Klára - Egyetemi Könyvtár Informatikai és Fejlesztési Osztály: szakmai tanácsadás;

- BME OMIKK;

- Ex-Lh Számítástechnikai Kft.;

- Országgyülési Könyvtár.

\section{Rezümé}

Az Egyetemi Könyvtári Szolgálat K21 minőségfejlesztési munkacsoportjai több alkalommal végeztek kérdőíves felmérést, melyben több felhasználó is kérte a dokumentumok kikérését megkönnyítő szolgáltatás bevezetését, és ezt az igényt a napi kiszolgálás során is jelezték a könyvtárosok felé. Ehhez kapcsolódva a tanulmányban bemutatom az elektronikus dokumentumkikérés bevezetésének folyamatát a tervezéstől, az egyeztető megbeszéléseken át a tesztelésig, majd a megvalósításig. Kitérek a korábbi dokumentumkikérés gyakorlatának ismertetésére. Részletesen írok az elektronikus kikéréshez kapcsolódó módosításokról, amelyeket az Aleph IKR-ben végeztünk el, melyek közül a lényegesebbek az új gyüjtemények kialakítása, egyes gyüjtemények rendezése, valamint a jogosultságok változtatása olvasói és példány oldalról is. Vázolom a web-OPAC-ban történt új beállításokat, módosításokat, az ürlap mezőinek kialakítását időszaki kiadvány és egyéb dokumentumok esetében, a mezők elnevezését, a kötelező mezők megjelölését, az automatikus beállításokat. Kitérek a nem raktári, a külső raktári és a bármely okból nem kikérhető dokumentumok esetében beállított üzenetekre. Tanulmányomat az olvasói visszajelzések és a statisztikai adatok ismertetésével zárom. 


\section{Service development adjusted to the needs of the library users in the University Library}

The K21 quality development groups of the University Library Service (EKSZ) have carried out surveys several times. Many of those who filled in the questionnaires and those who visited the library in person asked for the introduction of services that make document requesting easier. In this study I describe every aspect of this installation such as planning, consulting, testing and programming. I also present the old practice of document requesting. I write in detail about changes that were made in the Aleph ILS (integrated library system), such as the creation of new collections, arranging collections and making changes in the entitlements from reader and copy side. I also mention the new settings and modifications in web-OPAC, the creation of form fields in case of periodicals and other documents, the naming of the form fields, the marking obligatory fields and the automatic setup. I also present setup messages that contain information about documents that cannot be requested, and documents stored in off-site storages or at other places. Finally, I present statistics and the readers's feedback.

CZINKI-VIETORISZ GABRIELLA könyvtáros ELTE Egyetemi Könyvtár 


\section{"... gondjaink tesznek minket bátrakká ... "1 \\ Időszaki kiadványok elektronikus naplózása az ELTE Egyetemi Könyvtárban}

\section{A könyvtári munkafolyamatok változásai}

Az elmúlt évekre (évtizedekre) és napjainkra is egyaránt jellemző, hogy egyre több könyvtári szolgáltatás válik részben vagy egészében elektronikussá, és egyre nagyobb számban jönnek létre digitális vagy digitális születésű dokumentumokra épülő könyvtári szolgáltatások. Közös jellemzőjük, hogy erőteljes felhasználói igény vagy informatikai vívmány hívja életre öket. Részletesen tájékozódhatunk ezekről a szolgáltatásokról akkor is, ha intézményünkben még nem kerültek bevezetésre, hiszen a könyvtári szaksajtó nagy hangsúlyt helyez ismertetésükre, elemzésükre. A változásokkal párhuzamosan a minőségi könyvtári szolgáltatás stabil alapját képező feldolgozói munkafolyamatokban is megjelent az igény a digitális környezet kihívásainak való megfelelésre. A tanulmány célja egy ilyen folyamat bemutatása, melynek során az időszaki kiadványok hagyományos, papíralapú naplózása lezárult, és felváltotta az elektronikus napló készítése.

\section{Időszaki kiadványok állományba vétele}

Az időszaki kiadványok állományba vételét külön rendelet nem szabályozza, a 3/1975-ös KM-PM együttes rendeletben² leírtak tekintendők kötelező érvényünek, ami azonban nagy vonalakban csak annyit követel, hogy a nem átmeneti idöszakra (3 év) beszerzett dokumentumokról állománynyilvántartást kell vezetni.

„2. § (1) A könyvtár köteles minden dokumentumáról - a számvitel rendjéröl szóló 1968. évi 33. törvényerejü rendelet 3. és 6. \$-aiban foglalt rendelkezésekkel összhangban - folyamatosan és idösorrendben olyan állománynyilvántartást (leltárt) vezetni, amelynek alapján az állomány

${ }^{1}$ Peck, Morgan Scott A járatlan út. Budapest, Park Kiadó, 2014. Borító.

2 3/1975. (VIII. 17.) KM-PM együttes rendelet A könyvtári állomány ellenőrzéséről (leltározásáról) és az állományból történő törlésről szóló szabályzat kiadásáról (hatálybalépés: 1978. augusztus 17.) Forrás: http://net.jogtar.hu/jr/gen/hjegy_doc.cgi?docid=[-] 97500003.KMA [2015.07 20.] 
egészének a darabszáma és értéke, továbbá az egyes dokumentumok értéke bármikor megállapítható és ellenörizhetö." 3

A rendeletben hivatkozott 1968. évi 33. törvényerejü rendelet ${ }^{4}$ hatályát vesztette, helyette a 2000. évi C. törvény ${ }^{5}$ rendelkezései kötelezök. A könyvtári dokumentumok állománynyilvántartásáról az MSZ 3448-786 szabvány is rendelkezik, mely az időszaki kiadványok tekintetében kimondja: ,,3.6.2. Az időszaki kiadványok teljes évfolyamait illetve köteteit egyedi vagy összesitett állománynyilvántartásba kell venni. "7 Ebben a formában a szabvány több szempontból nehezíti az időszaki kiadványait köttető könyvtárak gyakorlatát. Például évkönyvek esetében az állományba vételnek kötetenként kell történnie. Ha több évkönyv kerül ugyanabba a kötési egységbe, kialakul az a speciális helyzet, hogy egy darab fizikai egység több egyedi leltárszámot tartalmaz.

Az időszaki kiadvány, mint speciális könyvtári dokumentum kezeléséről rendelkezö, és azt részletezö törvényi szabályozás hiányában eltérő szokások alakultak ki a periodikák naplózását illetően. Gyakori az évfolyam alapú naplózás, de arra is bőven van példa, hogy teljességgel hiányzik, illetve estleges a nyilvántartásba vételük. Ez utóbbi föként akkor fordul elö, ha egy könyvtár az évkönyvet könyv dokumentumként értelmezi, és mint ilyen, bekerül a könyvekről vezetett állománynaplóba. Ugyanakkor az újságok, folyóiratok naplózása elmarad. Sok helyen pedig a cardex lap tölti be a végleges állománynyilvántartás funkciót is.

\section{Az Egyetemi Könyvtár állománya, naplózási gyakorlata}

Az Egyetemi Könyvtár periodika állományának kezelése kiemelt helyet foglal el a gyüjtemény gondozásában, hiszen annak jelentős részét képezi a mintegy 250000 bekötött egység, amely megközelítően 15000 címet foglal magában, és az elmúlt évekre jellemző csökkenő tendencia ellenére is évente 700-900 kurrens cím érkezik be.

${ }^{3}$ I. m. I. fejezet Általános rendelkezések.

${ }^{4}$ 1968. évi 33. tvr. a számvitel rendjéről (XII. 7.) (hatálybalépés: 1969. január 1.). = Pénzügyi Közlöny, 1968, 35. sz. (dec. 17.) 737-740. p.

52000 . évi C. törvény A számvitelről (hatálybalépés: 2001. január 1.). Forrás: http://[-] net.jogtar.hu/jr/gen/hjegy_doc.cgi?docid=A0000100.TV [2015. 07. 20.]

${ }^{6}$ MSZ 3448-78 A könyvtári állomány nyilvántartása (hatálybalépés: 1980. január 1.). Budapest, MSZH, [1978.] 4 p.

${ }^{7}$ I. m. 3. Állománynyilvántartás. 
Az állomány naplózásának története régmúltra tekint vissza. A papíralapú naplózás 1953-ban indult, 22 évvel megelőzve a 3/1975-ös rendelet megjelenését. (Az azóta keletkezett leltárkönyvek több polcot is megtöltöttek, és mennyiségük folyóméterben is jól kifejezhetővé vált.) A Horizon integrált könyvtári rendszerben 2000 végétől valósult meg a hibrid naplózás (elektronikusan felvett adatokból papíralapú napló nyomtatása), amely korunk talán legelterjedtebb állománynyilvántartási gyakorlata, majd 2011-ben erősödött fel a kizárólag elektronikus napló készítésének igénye az Aleph integrált könyvtári rendszerre történő váltásnak köszönhetően. A szándék már korábban megfogalmazódott a párhuzamos, többszörös nyilvántartás csökkentésének igényével együtt. A legfontosabb érvek az alábbiak voltak: digitális környezetben a papíralapú dokumentumok hatékonysága megkérdőjelezhető, az erőforrás-optimalizáló és hozzáférhetőséget biztosító követelményeknek való megfelelés valamint a költségvetési megszorításokból adódó költségcsökkentő intézkedések.

Az Egyetemi Könyvtárban a naplózás alapja az évfolyam, évkönyvek esetében a kötet volt 2011-ig (bár található példa eltérésekre is, különösen visszamenőleges állományba vétel esetén), a naplózás esedékessége pedig az utolsó szám beérkezése. 2011-re határozott igény alakult ki a gyakorlat-alapú, olvasó/kölcsönzésbarát megoldásra, ezért a korábbi gyakorlatot módosítanunk kellett. Vizsgálva a könyves módszert, a naplózás új alapja a kötési egység lett, melynek indoka, hogy ha bármilyen esemény történik (például átirányítás, előjegyzés, kölcsönzés, könyvtárközi kérés, eltulajdonítás), az mindig a kötési egységgel történik, és nem feltétlenül az évfolyammal. Az évfolyam csak szerencsés esetekben tud egyetlen kötési egységbe kerülni, gyakoribb példa az, ha a teljes évfolyam több kötési egységet alkot, illetve egy kötési egység több évfolyamot is tartalmaz. A naplózás esedékessége továbbra is az utolsó tag beérkezésének időpontja maradt, hiszen így a legnagyobb az adatbiztonság, és az új módszerrel a naplózási és kötési elv is összhangba került. 


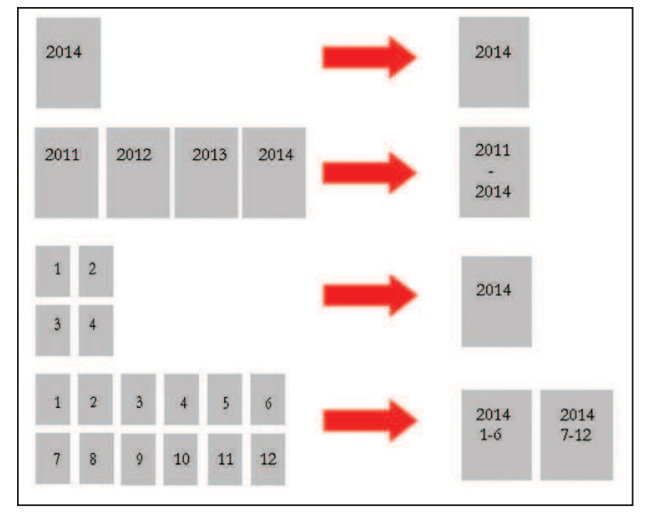

1. ábra. Általános kötési elv időszaki kiadványok esetében

Ahhoz, hogy az új naplózási elv az Aleph-ben is alkalmazható legyen, meg kellett vizsgálni a példányadat-kezelés lehetőségeit, a technikai megoldásokat, valamint a példányadatokba bekerülő e-adatokra építhető szerviz és lekérdező funkciókat. Abban az esetben, ha egy periodika önállóan kerül, vagy nem kerül köttetésre (tehát egy füzetszám, kötet egy kötési egység lesz), minden, a naplózásához szükséges adat felvételre kerül a saját, egyedi példányadatába. Akkor azonban, ha több évfolyamot kell megvárni a köttetéssel, illetve egy évfolyamból több kötési egység is keletkezik (vagyis egyetlen kötési egységhez több egyedi példányadat tartozik), létrehozásra kerül egy speciális példányadat-típus, a „periodika leltári példány". Ez az adat az olvasó számára nem látható, köttetésig az egyedi példányadatokkal párhuzamosan létezik, köttetés után azonban (az egyedi példányadatok törlésével) valódi példányadattá válik.

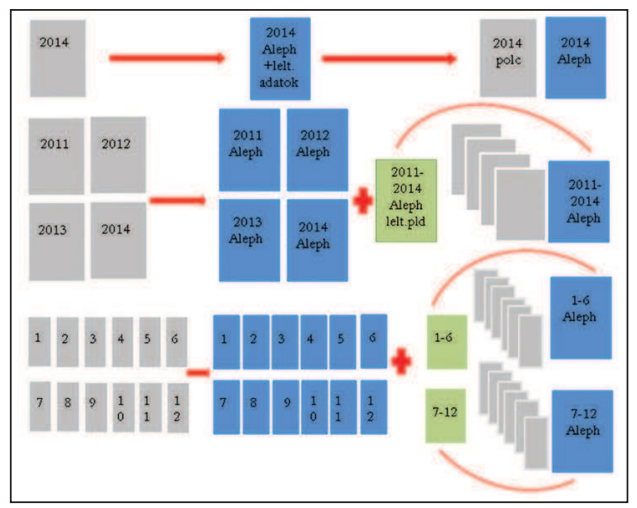

2. ábra. Időszaki kiadványok példányadatainak kezelési elve az Aleph integrált könyvtári rendszerben 
A periodika leltári példányadat tartalmazza a kötési egység egyedi információit: az egyedi azonosítókat (vonalkód, leltári szám, jelzet), a befoglaló tagok számozási adatait, az egyedi jellemzőket (például hiányok, kötési megjegyzések), a leltározáshoz szükséges adatokat (leltári szám, dátum, ár, beszerzés forrása, szállító), az elérhetőségre, szolgáltatásra vonatkozó információkat (például korlátozottan kölcsönözhető), a tagdokumentumok speciális, egyedi jellemzőit (például mellékletek, részcímek, tematikus címek).

\section{Az elektronikus leltárnapló}

A periodika leltári példányadatok, valamint a leltári adatot tartalmazó egyedi példányok adataiból a „Példányok-Inventory List” szerviz funkcióval könnyen összeállítható adott idöszak gyarapodási naplója. Egy elektronikus ürlap kitöltésével megadhatók a speciális feltételek, melyek alapján a program végrehajtja az adatbázis lekérdezését. A végeredményként kapott elektronikus lista a gyarapodási napló alapja. A ,riportoszlopok” tartalma, sorrendje lelőhelyenként személyre szabható, az adatforrások köre lehet a bibliográfiai rekord, példányadat és a szerzeményi modul is.

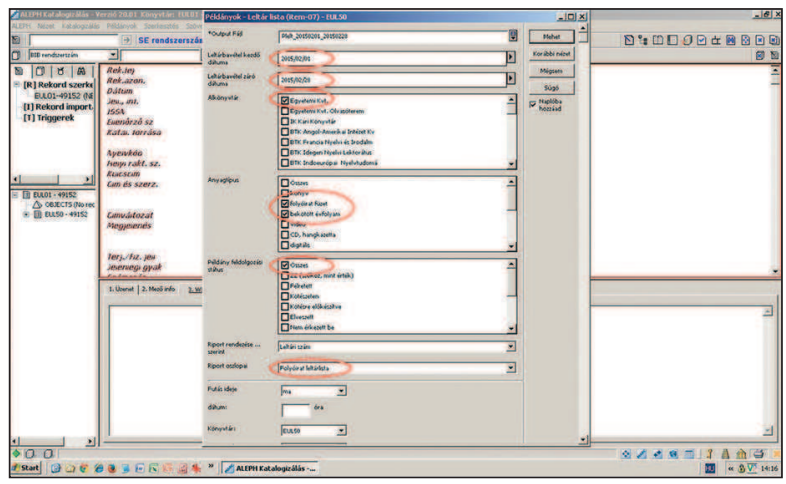

3. ábra. Elektronikus napló készítése szerviz funkció segítségével az Aleph integrált könyvtári rendszerben

Az Egyetemi Könyvtárban a periodika e-gyarapodási napló egy közös Excel-fájlba kerül átmentésre, így az összes dokumentumtípus, a teljes dokumentumállomány gyarapodási nyilvántartása egy helyen érhető el és férhető hozzá. Az adatvédelem az átmentést, ellenőrzést és jóváhagyást követően az oszlopok írásvédettségével biztosítható, így az adatok a továbbiakban nem felülírhatók. Egyetlen módosítható oszlop a „Megjegyzés" marad, ide kerülnek be az utólag felvett információk, a papíralapú naplózás gyakorlatával megegyezően. 
Az e-napló előnyei és hátrányai megegyeznek az elektronikus dokumentumokéval, legfontosabb jellemzői: tartalmazza az összes kötelező és szükséges információt, archiválható, megosztható, távolról elérhető, gyors visszakereshetőséget biztosít az adattartalomban, támogatja a statisztikai adatszolgáltatást és a statisztikai trend kimutatását, környezetbarát, helytakarékos. Az e-naplóval kapcsolatban sokáig megoldandó probléma volt a hitelesítés módja, melyre kielégítő megoldást kínál az integrált könyvtári rendszer által rögzített riport a példányadatok létrehozásáról, módosításáról.

A leltárnapló egyben pénzügyi okmány is, ezért a 3/1975-ös KM-PM együttes rendeleten kívül a számvitel rendjéről szóló jogszabály rendelkezései is vonatkoznak rá. Utóbbit hatályba lépése óta többször aktualizálták, legújabb, módosított verziója 2016. január 1-én lépett életbe. Az elektronikus leltárnapló formai és tartalmi tulajdonságainak a jogszabályoknak történő megfeleltetése összetett feladat volt. A felülvizsgálat eredményeképpen nem maradt olyan kitétel, melynek az új módszer ellentmondana. Előfordulnak azonban olyan, jelenleg még hatályban lévő jogszabályi követelmények, amelyeknek részben felel meg, bár ezen kritériumok esetében megfontolandó lenne szakmai indokoltságuk újragondolása.

Az állománynyilvántartásra vonatkozó kötelező elöírások:

- Minden dokumentumról folyamatosan, idösorrendben állománynyilvántartást vezet. Az e-napló ennek a szempontnak csak részben tud megfelelni, csakúgy, mint a papíralapú napló, hiszen nem a periodika füzetszámainak folyamatos, idősorrendben történő jegyzésére hivatott, hanem a leltári egységére. Az időszaki kiadvány füzeteinek, számainak, köteteinek beérkezésére, az időpont rögzítésére az MSZ 3448-78 szabványban is megengedett előzetes nyilvántartás szolgál.

- Megállapitható az állomány egészének darabszáma és értéke. Az e-napló alkalmas mindezen adat gyors és hatékony szolgáltatására.

- Megállapitható és ellenörizhetö az egyes dokumentumok értéke. Az e-napló alapján az egyes dokumentumok értéke bármikor megállapítható.

- Tartalmazza a dokumentum egyedi azonositásához szükséges és kötelezö adatokat. Az e-napló minden, az egyedi azonosításhoz elöírt, kötelező adatot tartalmaz.

- Tájékoztat a dokumentumok beszerzésének idejéröl és módjáról. Az e-napló ennek a feltételnek csak részben tud megfelelni (ahogy a papíralapú napló is), hiszen minden esetben tájékoztat a dokumentum 
beszerzésének módjáról, azonban az időszaki kiadványokhoz nem rendelhető egyetlen dátum, mint a beszerzés időpontja. Az időszaki kiadvány speciális dokumentum, mely egymást követő részegységekből áll. Kurrens állomány esetén (az évkönyv típusú periodikák kivételével) nem beszélhetünk egyetlen beérkezési/beszerzési időről, ilyen típusú információ csak a leltári egységbe tartozó részegységekhez rendelhetö, melyről az MSZ 3448-78 szabványban is megengedett elözetes nyilvántartás tájékoztat.

- Feltünteti a dokumentumok beszerzési árát, illetöleg a becsértékét. Az e-napló tartalmazza az árra vonatkozó információkat.

- Tartalmazza a dokumentum állományból törlésére vonatkozó utalást. A papíralapú leltárkönyv gyakorlatával megegyező módon, az utólag is módosítható megjegyzés oszlopnak köszönhetően az állományból törlésre vonatkozó utalások feljegyezhetők az e-naplóban is.

A pénzügyi okmányra vonatkozó kötelező elöírások:

- Folyamatosan számozott lapokból áll. Ez a kitétel nem feltétlenül indokolt írásvédelemmel ellátott elektronikus nyilvántartás és folyamatos leltári számsor esetében.

- Használatbavétel elött hitelesiteni kell. A kritérium teljesítésében nagy segítséget jelent a 2001. évi XXXV. törvény az elektronikus aláírásról. ${ }^{8}$

- Csak tollal vezethető. Ez a feltétel nem alkalmazható elektronikus nyilvántartás esetén.

- Téves bejegyzést egyszeri áthúzással és aláirással hitelesitett módon lehet javitani. Téves bejegyzések és a bejegyzöre vonatkozó információk felvételére a papíralapú leltárkönyv gyakorlatával megegyező módon, az utólag is módosítható megjegyzés oszlop szolgál.

- Nem selejtezhető. Az e-napló hosszú távú, megbízható tárolása egy arra alkalmas tárhely biztosításával megoldható.

2011-ben az Egyetemi Könyvtárban kialakult egy speciális helyzet, melynek eredményeképpen megszületett a döntés, hogy alkalmazkodva a digitális környezet és a megváltozott felhasználói szokások kihívásaihoz, az időszaki kiadványokról a továbbiakban elektronikus állománynyilvántartást vezetünk. Bátor döntés volt. Habár a gondjaink tettek minket bátrakká.

${ }^{8}$ 2001. évi XXXV. törvény az elektronikus aláírásról (kihirdetve 2001. június 12.). Forrás: http://net.jogtar.hu/jr/gen/hjegy_doc.cgi?docid=A0100035.TV [2015. 07. 20.] 


\section{Rezümé}

A tanulmány azt a folyamatot mutatja be, hogy mi indokolta és hogyan történt a hagyományos, papíralapú állományba vétel leváltása az elektronikus napló készítésére egy speciális dokumentumtípus, az időszaki kiadványok esetében az ELTE Egyetemi Könyvtárban. Megvizsgálja azokat a problémákat, melyek megoldása nélkül nem lett volna végrehajtható az áttérés. Bemutatja az állományba vétel elvének újragondolását, az elv összehangolását az integrált könyvtári rendszer által biztosított lehetőségekkel, valamint az elektronikus napló formai és tartalmi követelményeinek megfeleltetését a vonatkozó jogszabályoknak.

\section{Electronic inventory of periodicals in the University Library of ELTE}

The presentation shows the process, why and how the University Library of Eötvös Loránd University replaced the traditional paper-based inventory by creating electronic inventory in the case of a special type of document, the periodicals. It examines the problems that had to be solved in order to fulfill the change. It also explores the reconsideration process of inventorizing, the synchronization of the new principle with the integrated library system and the harmonization of requirements in terms of form and content of electronic inventory books with the relating law.

SZÉPVÖLGYI KATALIN könyvtáros ELTE Egyetemi Könyvtár 


\section{Tervek és tények}

\section{Az ELTE Egyetemi Könyvtári Szolgálat kulturális szakembereinek képzése a szolgáltatások fejlesztése érdekében címü TÁMOP-3.2.12-12/1/KMR-2012-0007 pályázat eredményei}

Az Új Széchenyi Terv (ÚSzT) átfogó célja a foglalkoztatás bővítése, tartós növekedés, amelyen belül a Társadalmi Megújulás Operatív Program (TÁMOP) az emberi erőforrások fejlesztését támogatta. Ennek a 3. prioritási tengelyében a minőségi oktatás és hozzáférés biztosítását mindenkinek, ezen a belül a 3.2 intézkedés a közoktatási rendszer hatékonyságának javítását, újszerü megoldások és együttműködések kialakítását ösztönzi az ÚSzT. E pályázati rendszerben a TÁMOP 3.2.12 konstrukció a Kulturális szakemberek továbbképzését és a szolgáltatások fejlesztését támogatta, azaz a pályázat az élethosszig tartó tanulás új tanulási formáinak elterjedését segítő, korszerü ismeretekkel rendelkező kulturális szakemberek számát és ezekhez az új formákhoz kapcsolódó szolgáltatások szélesebb körü rendelkezésre állását kívánta biztosítani. ${ }^{1}$

A 2012-ben megjelent pályázat meghirdetésekor az elszámolható közkiadásokra a Közép-magyarországi régióban 435765700 Ft, a konvergencia célkitüzés alá eső régiókban 1456815907 Ft keretösszeg állt rendelkezésre. E forrásból részesült az ELTE Egyetemi Könyvtári Szolgálata is a 2013. január 1. és 2014. december 31. között megvalósított projektben. ${ }^{2}$

A pályázati felhívás alapján a célcsoportja a kulturális szakemberek szervezett képzési rendszeréről, követelményeiről és a képzés finanszírozásáról szóló 1/2000 (I.14.) Nemzeti Kulturális Örökség Minisztérium rendelete alapján a muzeális intézményekről, a nyilvános könyvtári ellátásról

${ }^{1}$ Új Széchenyi Terv akciótervei 2011-13. Forrás: https://www.palyazat.gov.hu/[-] doc/2670 [2015.12.05.]

${ }^{2}$ Jakab László (Programirányító Nemzeti Fejlesztési Ügynökség, Humán Erőforrás Programok Irányító Hatósága): Uniós pályázati források a kulturális szakemberek továbbképzésére a Társadalmi Megújulás Operatív Program keretében. Elhangzott a Mühelybeszélgetés a könyvtárak számára kiírt TÁMOP-pályázatokról címü rendezvényen, 2012. április 24. Forrás: http://ki.oszk.hu/content/t-mop-3212-kultur-lis-szakemberek-[-] tov-bbk-pz-se-szolg-ltat-sfejleszt-s-rdek-ben [2015.12.05.] 
és a közmüvelödésröl szóló 1997. évi CXL. törvény hatálya alá tartozó intézmények (kulturális intézmények: muzeális intézmények, közmüvelődési intézmények, könyvtárak, és a 94.§ (4) alapján a levéltárak) közalkalmazotti vagy munkaviszony alapján szakmai munkakörben, legalább 6 órában foglalkoztatott közép- és felsőfokú végzettségü szakemberei. ${ }^{3}$

A programban támogatható oktatási formák az alábbiak voltak:

1. A kultúráért felelős miniszter által akkreditált, tanfolyam jellegü szakmai továbbképzések.

2. Az Országos Képzési Jegyzékben (OKJ) szereplő iskolarendszeren kívüli formában, kulturális területre vonatkozó szakképesítést adó kurzusok.

3. Felsőoktatási intézmény által folytatott, kulturális területre vonatkozó szakirányú továbbképzések.

\section{Tervek és tények}

Az Egyetemi Könyvtári Szolgálat (EKSz) az ELTE egységes alapelvek szerint müködő, összehangolt szolgáltatásokat nyújtó könyvtári rendszere, amely 2009-ben az ELTE Szenátusának XXXIV/2009. (III.23.) számú határozata alapján jött létre. Az Egyetemi Könyvtár az EKSz munkatársainak képzésére adott be pályázatot, amelyben az elnyert összeg $25843907 \mathrm{Ft}$ volt. A résztvevő szervezeti egységek köre: Állam- és Jogtudományi Kar Kari Könyvtár, Bárczi Gusztáv Gyógypedagógiai Kar Kari Könyvtár és Gyógypedagógia-történeti Gyüjtemény, Bölcsészettudományi Kar Központi Olvasóterme és az intézeti könyvtárai, Egyetemi Könyvtár, Egyetemi Levéltár, Informatikai Kar Kari Könyvtár, Pedagógiai és Pszichológiai Kar Kari Könyvtár, Tanító- és Óvóképző Kar Kari Könyvtár, Társadalomtudományi Kar Kari Könyvtár, Természettudományi Kar Kari Könyvtár.

A pályázat projektmenedzserét és pénzügyi vezetőjét az Egyetemi Könyvtár biztosította. A projektmenedzsmenten, az elvárt nyilvánosság biztosításán és a közbeszerzési költségeken kívül a büdzsé $84 \%$-át a célcsoport számára biztosított szolgáltatások (képzések ellenértékei, a projektbe bevontakat helyettesítők bére és járulékai) tették ki.

A következö táblázatban összesített adatok láthatók a pályázati tervről, és a megvalósítási értékekről a képzések és fajtáik, a pályázatba bevont személyek száma és a költségvetési végösszeg alapján.

${ }^{3}$ Pályázati útmutató a Társadalmi Megújulás Operatív Program Kulturális szakemberek továbbképzése a szolgáltatásfejlesztés érdekében c. pályázati felhívásához. Kódszám: TAMOP - 3.2.12-12/1/KMR. Forrás: https://www.palyazat.gov.hu/doc/3422 [2015.12.05.] 


\begin{tabular}{|l|r|r|r|}
\cline { 2 - 4 } \multicolumn{1}{c|}{} & \multicolumn{1}{c|}{ Terv } & \multicolumn{1}{c|}{ Tény } & Eltérés \\
\hline Képzés & 166 & 255 & $154 \%$ \\
\hline Képzésfajta & 38 & 30 & $79 \%$ \\
\hline Óraszám & 17590 & 11880 & $68 \%$ \\
\hline Fö & 88 & 76 & $86 \%$ \\
\hline Költségvetés & $29617318 \mathrm{Ft}$ & $24154886 \mathrm{Ft}$ & $82 \%$ \\
\hline
\end{tabular}

\section{Képzési tényadatok}

A pályázat kétéves megvalósítása alatt 76 fő 255 - hosszabb-rövidebb oktatáson vett részt.

A támogatott képzést e három feltétel teljesülése esetén tekintette sikeresnek a pályázat kiírója:

1. Valamennyi, a pályázatba bevont szakembernek legalább 60 óra időtartamú képzésen kellett részt vennie. E minimumkövetelmény több tanfolyamon való részvétellel is teljesíthető volt, de valamennyi igénybevett kurzus időtartamának el kellett érnie legalább a 30 órát.

2. A bevont kollégáknak el kellett végezniük a képzéseket, ezt minden résztvevő sikeresen teljesítette.

3. A tanfolyamoknak, kurzusoknak a fejlesztendő intézmény valamely - jelenlegi vagy jövőbeni - szakmai tevékenységéhez kellett kapcsolódnia. Az eredményeket a Szolgáltatásfejlesztés részben ismertetem.

\begin{tabular}{|c|c|c|}
\hline Elvégzett képzések száma & Fö & Össz képzés szám \\
\hline 1 & 8 & 8 \\
\hline 2 & 19 & 38 \\
\hline 3 & 19 & 57 \\
\hline 4 & 16 & 64 \\
\hline 5 & 5 & 25 \\
\hline 6 & 6 & 36 \\
\hline 7 & 1 & 7 \\
\hline 8 & 0 & 0 \\
\hline 9 & 1 & 9 \\
\hline 10 & 0 & 0 \\
\hline 11 & 1 & 11 \\
\hline Összesen & 76 & 255 \\
\hline
\end{tabular}


Az egy képzésre járók jellemzően 60 órás kurzusokon vettek részt, kivételt a Könyvtári Intézet (KI) Segédkönyvtáros tanfolyamát 450-450 órában teljesítők jelentették. A két oktatáson résztvevők túlnyomórészt 2×30 órás bontásban tettek eleget a pályázatban elöírtaknak. A 3-11 képzést teljesítők mindannyian a többszörösét végezték el az elvárt minimum óraszámnak, három kollégánk - ketten a Természettudományi Kar Kari Könyvtárából, egy az Egyetemi Könyvtárból - kiemelkedően aktív volt a maga 11, 9, ill. 7 kurzusával.

\begin{tabular}{|l|r|}
\hline \multicolumn{1}{|c|}{ Képzésfajta változása és okai } & Képzések száma \\
\hline Tervezett képzésfajták száma & 38 \\
\hline $\begin{array}{l}\text { A képzést töröltük, mert a képző intézmény nem indította el a } \\
\text { képzést }\end{array}$ & 9 \\
\hline A képzést töröltük, mert más képzést választottak a jelentkezök & 2 \\
\hline A képzést töröltük, mert a képzést tervező résztvevő visszalépett & 11 \\
\hline Új képzések száma & 30 \\
\hline Ténylegesen elvégzett képzésfajták száma & \\
\hline
\end{tabular}

Bár igen hosszú előkészítő munka előzte meg a pályázat beadását, és gondosan felmértük az igényeket, az eredetileg tervezett oktatásoknak (38 féle) csak a fele (19 féle) valósult meg. Ennek több oka is volt. Egyrészt a pályázat megvalósítási időszakában, 2013 szeptemberében módosult az OKJ-s képzések rendszere. Ennek okán a tervezett - régi típusú tanfolyamokat a képző intézmények már nem indították el, az új típusúakat - amelyek egyúttal hosszabbak és drágábbak lettek - pedig még nem hirdették meg, s a változások miatt már nem fértek bele a költségvetési keretbe vagy a képzést tervező elképzeléseibe. Másrészt a tervezett képzések között szerepeltek olyan tanfolyamok, amelyek megfelelő számú érdeklődő hiányában mégsem valósultak meg, noha a képző intézmény meghirdette. Ilyen volt például a KI orosz szaknyelvi kurzusa. Harmadrészt életkörülmények megváltozása miatt a kollégák már nem tudták vállalni a tanulással járó terhelést, ezért inkább visszaléptek a megjelölt oktatástól. A kimaradó képzések helyére szerződésmódosítás után 11 újat vettünk fel a portfólióba. 


\section{Személyi változások és okai}

\begin{tabular}{|l|l|}
\hline Résztvevő & Fö \\
\hline Tervezett & 88 \\
\hline Törölt & 25 \\
\hline Új & 13 \\
\hline Tény & 76 \\
\hline
\end{tabular}

Nemcsak a tanfolyamokban, hanem a képzésen résztvevők személyében és számában is történtek változások. Az eredetileg tervezett 88 fó 71\%-a (63 fö) került bevonásra, 13 fó újként, a pályázat megvalósítása közben került a programba. A kiesők egy része munkahelyváltás, nyugdíjazás vagy visszalépés miatt került törlésre. Ezen kívül 2013-2014 folyamán az Egyetemi Könyvtárban a költségvetési megvonások miatt igen súlyos, 39\%-os leépítésre került sor, amely érintette a pályázatban résztvevőket is. Egyrészt emiatt, másrészt a megmaradók megnövekedett munkaterhelése következtében sokan már nem tudták vállalni a képzésekkel járó többletfeladatokat.

A programban résztvevők és a képzésfajták számának csökkenése ellenére a tervezett képzésszámot (166) 153 \%-osan (túl)teljesítettük: öszszesen 255 kurzust valósítottak meg a bevont kulturális szakemberek. Köszönhető volt ez annak, hogy leginkább a hosszabb, OKJ-s tanfolyamok vagy felsőfokú intézmény által szervezett szakirányú továbbképzések maradtak ki, és helyettük a rövidebb, például 30 órás akkreditáltak kerültek be a képzési portfólióba.

A teljesített 11880 tanfolyami óra résztvevői mellett a pályázat megvalósításában, a háttérben részt vett gyakorlatilag minden könyvtári kolléga. Ök biztosították a szolgáltatásokat, hogy a hiányzások ellenére a könyvtárak teljes körü müködése minél zökkenőmentes legyen, a lehető legtöbb belső munkafolyamat a szokásos rend szerint valósuljon meg. Az ö többletmunkájuk kompenzálására a projekt biztosított forrásokat: öszszesen 3100 órányi helyettesítést számoltunk el, ez a teljes óramennyiség 26\%-a. Miért ilyen keveset? A legfőbb ok a bonyolult ügymenet, és a rendkívül aprólékos dokumentáció volt, amit kevesen vállaltak.

Egy 2010-ben elvégzett szervezetikultúra-felmérés, és egy részleges önértékelés tanulsága szerint ${ }^{4}$ az EKSz erőssége a humánerőforrás szem-

${ }^{4}$ Ficzkó Zsuzsanna: Beszámoló az ELTE Könyvtári Szolgálat K21 Minőségfejlesztési Projektje által megvalósított önértékelésről. Készült: 2010. december 10. Forrás:

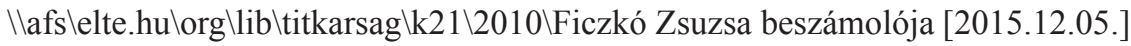


pontjából, hogy megfelelő számú és képzettségü munkatárssal rendelkezik. Ugyanakkor tapasztalható és mérhető volt, hogy az új szolgáltatások fejlesztéséhez és müködtetéséhez szükséges korszerü tudás hiányzott a szervezetböl. Ezek a területek: kommunikációs ismeretek és technikák, digitalizálási tevékenységgel és elektronikus adatfeldolgozással kapcsolatos ismeretek, ügyfelek kezelése, tananyagfejlesztés. A korosztályi öszszetétel szerint a munkatársak nagy része (81\%) még úgy szerezte meg a diplomáját, hogy ahhoz nyelvvizsga nem volt szükséges, míg az idegen nyelv ismerete nemcsak a szolgáltatások nyújtása, hanem az új ismeretek megszerzése szempontjából is fontos. Mindezek alapján a következő képzési lista állt össze:

- A tudomány mérése - Bibliometriai ismeretek, a szakirodalom feltérképezése

- Angol szaknyelvi ismeretek könyvtárosoknak

- Digitális és virtuális könyvtárak a tájékoztató munka szolgáltában

- Egyéni információmenedzsment

- Elektronikus könyv (e-book a könyvtár világában)

- Felkészülés a korszerü használóképzésre

- Felkészülés a minőséget szolgáló minőségi önértékelésre

- Interaktív portálok üzemeltetése könyvtári környezetben

- Iránytü a kézbe, stratégia és tervezés

- Kiállítások szervezése

- Konfliktushelyzetek hatékony kezelése könyvtári környezetben

- Konnektivizmus - hálózati tudásépítés a könyvtárosok gyakorlatában

- Könyvtári partnerkapcsolatok (szervezeti kultúra, szakmai önismeret)

- Könyvtárvezetői ismeretek 1-4.

- Kulturális és közhasznú tartalmak internetes megjelenítése könyvtári környezetben

- LINUX operációs rendszer és használata 1-2.

- Minőség értékelése a könyvtárakban

- Nyelvi képzés (angol, német)

- Segédkönyvtáros képzés

- Ügyfélszolgálati tréning a könyvtári minőségfejlesztésért 1-2.

- Vezetö-Szerep-Játék

- Web2-es készségek a mindennapi online információáramlásban

- Webes kompetenciák a könyvtáros szakmában 
Bár a pályázat megvalósítási ideje 2 év volt, ennél sokkal több időt ölelt - és ölel - fel a munka. A pályázat előkészítését - igényfelmérés, képzések keresése, költségvetés tervezése - még 2011-ben kezdte el Makkos László, az Egyetemi Könyvtár akkori humánerőforrás referense. A 2012 áprilisában megjelent pályázatot július 20 -án adtuk be, amelyet a Nemzeti Fejlesztési Ügynökség (NFÜ) július 23-án befogadott. A szeptemberi tisztázó kérdések megválaszolása után 2012. október 11-én megkaptuk a támogató döntést, majd december 11-én az aláírt támogatói szerződést. Még a szerződés kézhezvétele előtt, 2012 novemberében elkezdtük a nyelvi képzések közbeszerzésének előkészítését, de ennek ellenére is csak 2013 szeptemberében tudtuk elkezdeni a nyelvi tanfolyamokat. ${ }^{5}$ Az első képzést még el sem indítottuk, amikor 2013 áprilisában a pályázatokat kezelő szervezet, az ESZA Társadalmi Szolgáltató Nonprofit Kft. ellenőrzést tartott a program haladásával kapcsolatban. Az első képzési nap 2013. április 11-e, az utolsóé pedig 2014. december 15-e volt.

A projekthez kapcsolódó végelszámolást 2015. február 28-án nyújtottuk be, amelyet a július 15-i teljes körü helyszíni ellenőrzés után 2015. július 30-án elfogadott a támogató hatóság, és ezzel a pályázat megvalósulását elismerte. Az Egyetemi Könyvtárnak és a megvalósító helyszíneknek további 5 éves fenntartási kötelezettsége van, így 2019. december 31-én tekinthetjük majd teljesen lezártnak munkát.

\section{Szolgáltatásfejlesztés}

A pályázat keretében elvégzett képzések területéhez minden esetben kapcsolódott valamilyen már meglévő vagy fejlesztés alatt lévő intézményi szolgáltatás. Ezek:

- Az alapvető idegen nyelvü kiszolgálás és kommunikáció minden karon legalább egy könyvtárban, az Egyetemi Könyvtárban és az Egyetemi

${ }^{5}$ A nyelvi képzések beszerzésének bonyolultságát egyrészt az adta, hogy jogi szempontból az általános nyelvi képzések, a szaknyelvi képzések és a jelnyelvi képzések egy kategóriába tartoznak, így az összeszámítás szabálya alá esnek. Képzők szempontjából azonban lehetetlen volt olyat találni, amelyik mindhárom kategóriában aktív, vagy legalább vállalkozik arra, hogy a hiányzó területre külső céget vegyen igénybe. Másrészt a képzésen résztvevők száma és a képzések kínálata folyamatosan változott, így módosítva folyamatosan a közbeszerezni kívánt nyelvi képzések összértékét. Harmadrészt a szervezési időszak alatt a Közbeszerzésekről szóló 2011. évi CVIII. törvényt többször módosították, amely minden alkalommal új helyzetet teremtett. 
Levéltárban biztosított legyen. A nemzetköziesedés egyik alappillére lehet a közösségi és tudástérként müködő könyvtár, ahol elengedhetetlen az idegen nyelvet rutinosan használó kulturális szakember.

- Elkészült a könyvtárak második önértékelése, amelynek segítségével feltérképezésre kerültek a könyvtárak müködésének erősségei, gyengeségei és a fejlesztendő területek. Ennek eredményeképpen intézkedési terv készült a változtatások végrehajtására és a szolgáltatások javítására.

- Oktatói és hallgatói igény- és elégedettségfelmérés készült. Az eredményeket az önértékeléshez kapcsolódó akcióterv készítéséhez használtuk fel.

- Digitális tartalmakkal gyarapodott az ELTE Digitális Intézményi Tudástár (EDIT - http://edit.elte.hu).

- Az Egyetemi Könyvtári Szolgálat (http://konyvtar.elte.hu) portál tartalma folyamatosan bővül, egyre több idegen nyelvű információ kerül bemutatásra.

- A Magyar Tudományos Mủvek Tárához kapcsolódó, az ELTE kutatóit, oktatóit segítő adminisztrátori hálózat szakismeretei gyarapodtak, aminek hatására emelkedett a feladatellátás hatékonysága.

A fenti szolgáltatások és a megszerzett korszerü tudás fenntartásának forrásaiként a következőket jelöltük meg a pályázatban:

- Az intézmények költségvetése: a kialakított szolgáltatások beépülnek az operatív munkafolyamatok sorába, így azok ellátása munkaköri feladattá válik.

- Az intézmények saját bevétele: ebből biztosítható például a szolgáltatásokhoz szükséges infrastruktúra korszerüsítése.

- Pályázati források: a fejlesztett szolgáltatásokkal, a munkatársak korszerübb tudásával több pályázatban és sikeresebben vehetünk részt.

A szüken vett két, illetve a teljes pályázati időszak eddigi három évében az Egyetemi Könyvtári Szolgálat szinte minden munkatársa valamilyen formában részt vett a tervezett feladatok megvalósításában. Mindenkit köszönet illet meg az erőfeszítésekért, a lelkes munkáért, a szorgalmas tanulásért! 


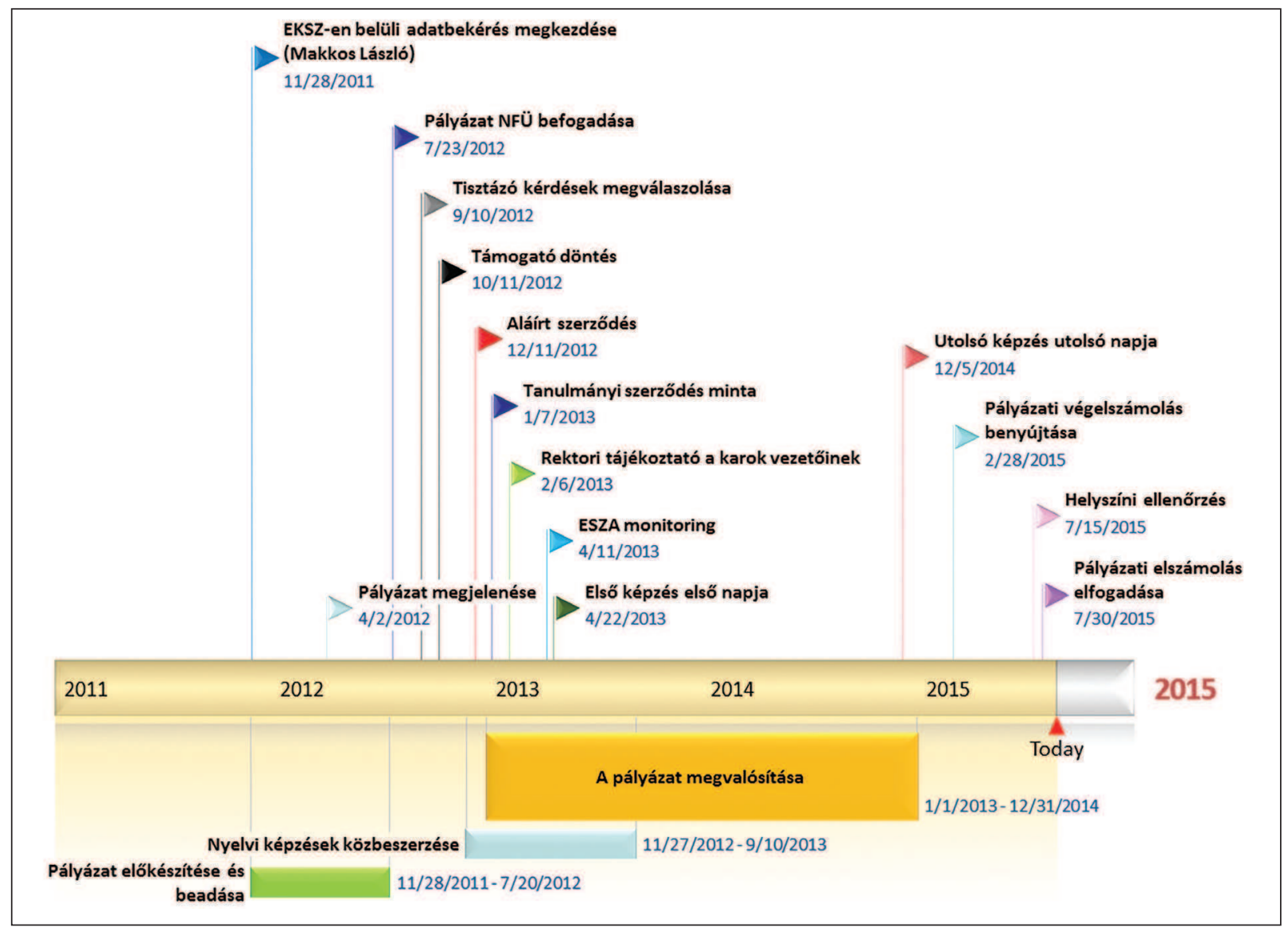

1 ábra. A pályázat megvalósítása 


\section{Rezümé}

Az ELTE Egyetemi Könyvtári Szolgálat kulturális szakembereinek képzése a szolgáltatások fejlesztése érdekében című TÁMOP-3.2.12-12/1/KMR-20120007 pályázat célkitűzéseit és eredményeit mutatja be a cikk a terv és a tény adatok segítségével.

\section{Plans and Achievements}

The results of the eTraining of cultural professionals of the ELTE University Library Service to improve services" TÁMOP-3.2.12-12/1/KMR2012-0007 project

This article presents the "Training of cultural professionals of the ELTE University Library Service to improve services" (TÁMOP-3.2.12-12/1/KMR-20120007) project's aims and results by analysing plan data and actual data.

VARGA KLÁRA osztályvezető

ELTE Egyetemi Könyvtár 


\section{TUDOMÁNYOS, INTÉZMÉNYI REPOZITÓRIUMOK ÉS JOGI KÉRDÉSEIK}





\section{EDIT apró lépései, nagy ugrásai}

Születésnapot ünneplünk, idén szeptemberben lesz két éves az ELTE Digitális Intézményi Tudástár (EDIT). Létrehozásának gondolata már jóval korábban megszületett. Gondos tervezés, hosszabb fejlesztési és elökészítési időszak után, 2013 szeptemberében elérhetővé tettük az edit.elte.hu webcímen (https://edit.elte.hu).

\section{Az EDIT gyarapodása}

Az első apró lépés nekünk nagy ugrásnak számított, mintegy 1700 feltöltött tétellel kezdte meg müködését, majd októberben újabb, közel 2500 tétellel gazdagodott. A gyarapodás mértéke a következő hónapokban, mint ahogy az a diagramon is látható (1. ábra) igen ingadozó volt. Ez a hónapról hónapra változó tételnövekedés sok mindentöl függött, a feltöltött dokumentumtól, az egyes gyüjteményeknél meghatározott munkafolyamatoktól, erőforrástól vagy a feltöltés módjától.

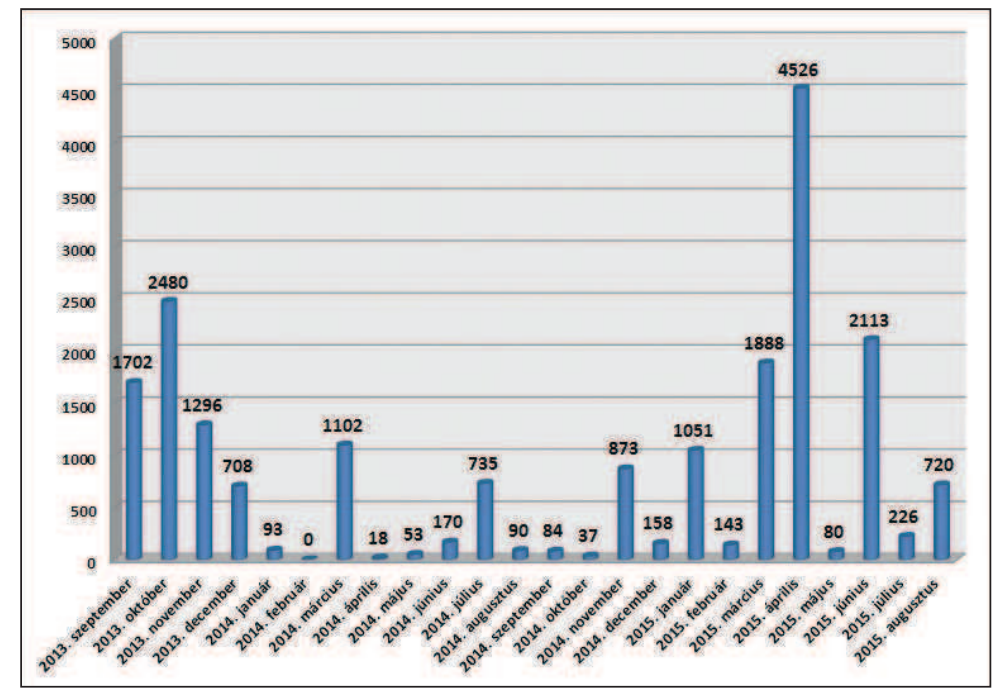

1. ábra. A gyarapodás mértéke az első két évben

\section{Feltöltés a repozitóriumba}

Az EDIT-be jelenleg háromféleképpen tölthetünk fel dokumentumot: 
1. A SWORD (Simple Web-service Offering Repository Deposit) protokoll segítségével az MTMT-be már felvett tudományos publikációk kerülhetnek be. A feltöltés az MTMT-ből kezdeményezhető, egyszerüen, pár kattintással a metaadatok ismételt magadása nélkül, valamint a fájl csatolásával a dokumentum eljuttatható az intézményi repozitóriumba.

2. A könyvtári katalógusunkban feldolgozott dokumentumok metaadatait egyszeri, csoportos áttöltéssel jelentetjük meg az EDIT-ben. Dublin Core metaadatsémát használunk, míg az elektronikus könyvtári katalógusban (ALEPH integrált könyvtári rendszer) MARC21 szabvány szerint katalogizálunk, ezért a csoportos áttöltés hosszabb előkészítést igényel, megfeleltetést végzünk, a metaadatokat pedig egyedi azonosítók alapján kapcsoljuk össze a digitalizált fájlokkal.

3. A harmadik lehetséges feltöltési mód az ürlapkitöltés, melynél a különböző dokumentumtípusokhoz különböző ürlapok állnak rendelkezésünkre. A feltöltés ebben az esetben lépésekre bontható. A kezdő lépés a gyüjtemény és az ürlap kiválasztása, amely után következik a leíró rész, ahol a metaadatokat rögzítjük, illetve a fájl(ok) feltöltése. Az ellenőrző „oldalon” áttekinthetjük a kitöltött adatokat, és lehetőség nyílik a módosításukra is. Ezt követően el kell fogadnunk az elhelyezési megállapodást, amely elhagyása nélkül nem fejezhetö be a feltöltés. A rögzített tétel minden esetben adminisztrátori munkafelületre érkezik, ahonnan ellenőrzés után kerülhet a nyilvános felületre.

A diagramon (2. ábra) a különböző módszerrel feltöltött tételek darabszámát szemléltetem.

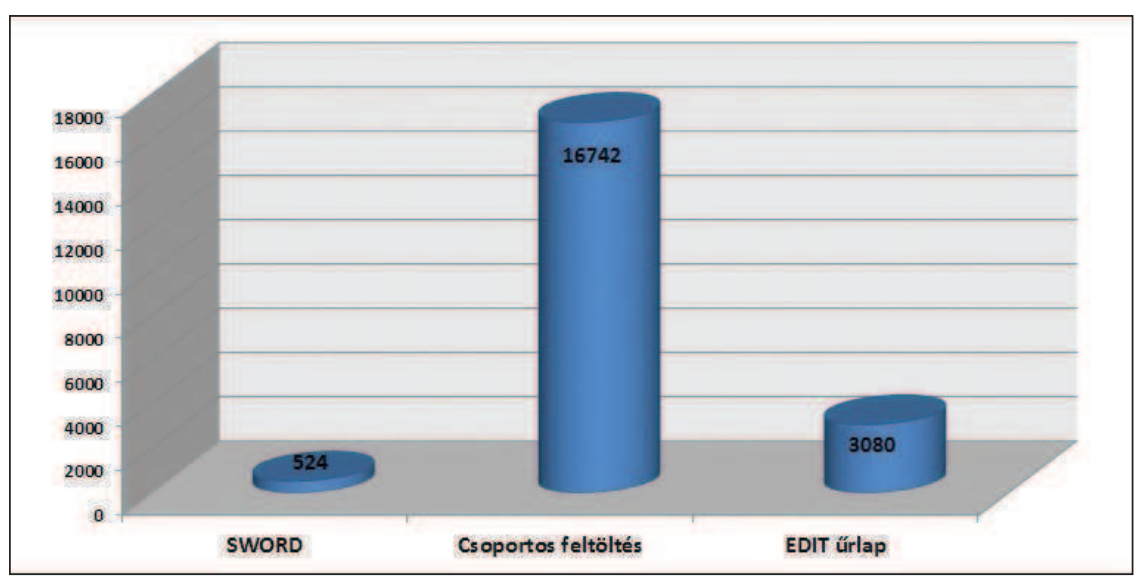

2. ábra. Tételek darabszáma feltöltési módok szerint 


\section{A tartalom megoszlása}

Az EDIT szerkezete hierarchikus gyűjteménystruktúra. A feltöltött tételek gyüjteménybe, a gyüjtemények pedig kategóriába rendeződnek. Kialakításukat az ELTE szervezeti felépítése, nagysága, valamint a tárolni kívánt dokumentumok széles köre is befolyásolta. A szerkezetet a lehetőségeinkhez mérten időnként alakítjuk, javítgatjuk. A jelenleg látható, 13 főkategóriába rendezett közel 90 gyüjteményben már több mint 20000 tétel található. Most ezeket 6 csoportba rendeztem: könyvtári dokumentumok, különgyüjtemények; ELTE folyóiratok, kiadványok; tudományos publikációk; doktori disszertációk; szakdolgozatok; végül az egyéb csoportba olyan dokumentumokat soroltam, mint a fotók, videók, hírlevelek, szabályzatok, tájékoztató anyagok, segédletek vagy irattári anyagok. Az alábbi diagramon (3. ábra) a feltöltött tételek darabszáma látható.

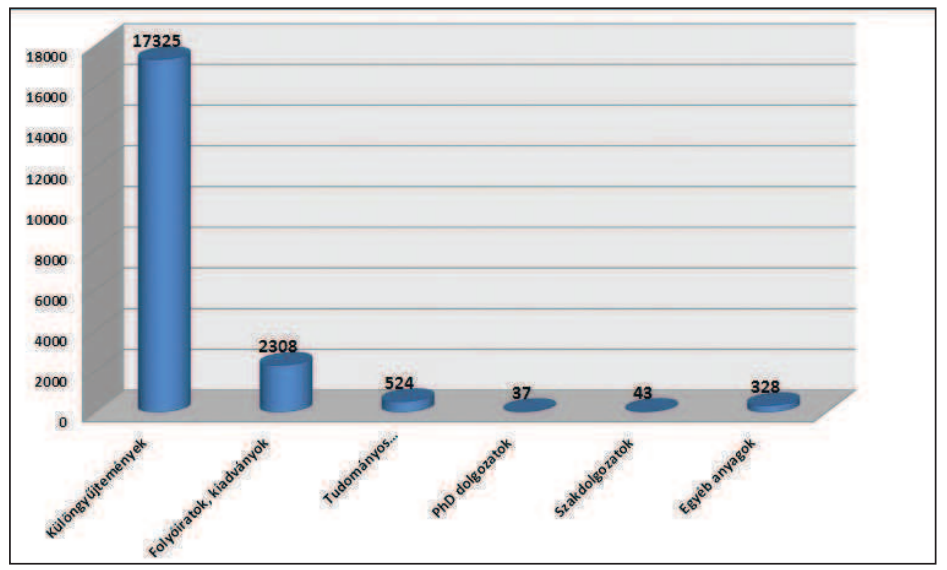

3. ábra. Az EDIT-ben megtalálható tételek 6 csoportra bontva

\section{Az EDIT üzemeltetése}

Az egyes gyüjtemények gyarapítása különböző munkafolyamatokat igényelhet, melyekben az ELTE polgárok szerepe más és más lehet. Az EDIT alapvetően önfeltöltésre épül, amely folyamat részeként a feltöltő elhelyezési megállapodást fogad el (de a szerző emellett védheti dokumentumát Creative Commons Licence használatával is). Az EDIT üzemeltetéséhez adminisztrátori hálózatot építettünk ki, melynek tagjai az egyetem könyvtárosai. Az EDIT-et és adminisztrációs hálózatát az Egyetemi Könyvtár koordinálja, a fejlesztéseket, karbantartást két informatikus végzi. Az intézményi adminisztrátor mellett, egy-egy kiemelt gyüjteményhez rendelt, 
további 3 egyetemi könyvtári dolgozó és 20 kari könyvtáros látja el az adminisztrátori feladatokat.

\section{Munkafolyamatok}

A különböző gyüjtemények gyarapításához különböző munkafolyamatokat dolgoztunk ki, melyekhez folyamatleírást, szemléltetéséhez pedig folyamatábrát készítettünk.

\section{Könyvtári dokumentumok}

A digitalizált könyvtári dokumentumok, különgyüjtemények EDIT-ben szerepeltetéséhez az informatikus és könyvtáros kollégák együttmüködésére volt szükség, hiszen ezek nagy része csoportos feltöltéssel került a repozitóriumba. A feldolgozást a könyvtárosok végezték, a digitalizálásban nagy segítségünkre volt a MaNDA közfoglalkoztatási program, melynek keretében kezdetben 15, majd később 10 fös csapatot fogadhattunk. Az EDIT-be töltést ugyan egy hosszabb és alaposabb munka előzte meg, azonban ez végül gyors és látványos gyarapodást eredményezett. A bibliográfiai leírások az Aleph integrált könyvtári rendszerben készültek. A fájlokat a dokumentum jelzetei alapján neveztük el, így biztosítva a fájl és a bibliográfiai leírás összekapcsolását. Az áttöltést amennyire lehetett automatizáltuk, előzőleg azonban a MARC21 szabvány szerint elkészült bibliográfiai leírás minden mezőjét, almezőjét megfeleltettük a Dublin Core metaadatséma elemeinek. Az egyedi azonosítók, linkek segítségével a könyvtári katalógus rekordjait az EDIT tételeihez kapcsoltuk.

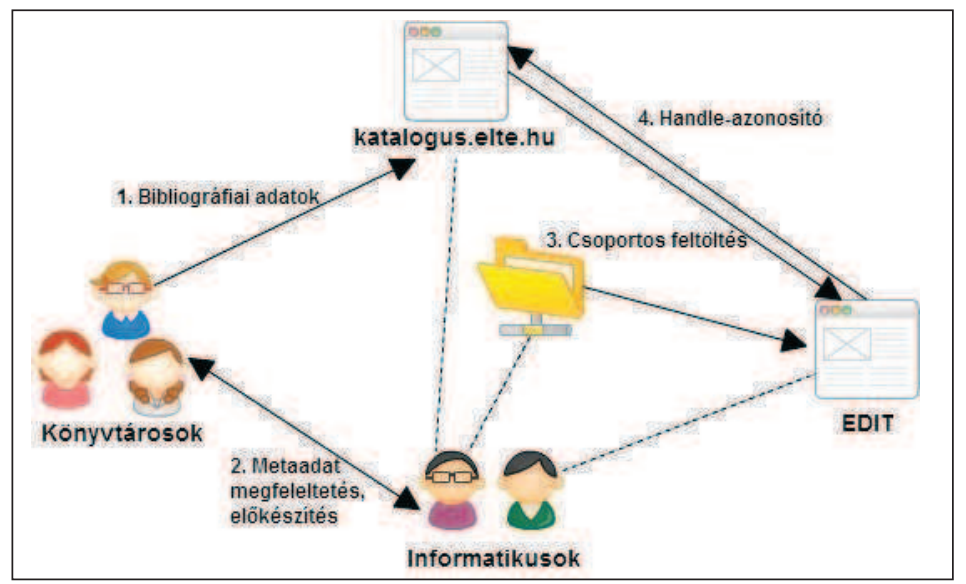

4. ábra. Könyvtári dokumentumok, különgyüjtemények - folyamatábra 
Folyóiratok, kiadványok

Az ELTE folyóiratok, kiadványok feltöltéséhez az ürlapokat használjuk. Az egyes kiadványok saját gyüjteményekben kapnak helyet. A gyüjteményenkénti egyéni jogosultságkezelés, mely regisztrációhoz kötött, több lehetőséget biztosít számunkra. A feltöltést bármely ELTE polgár végezheti, adott esetben akár a szerző is, vagy a szerkesztőség munkatársai, esetleg a könyvtárosok. A kiadótól open access nyilatkozat mellett egyéni elhelyezési megállapodást is kérünk. A feltöltés, valamint a bibliográfiai adatok és a fájl egyezőségének ellenőrzését, majd a jóváhagyást könyvtáros végzi.

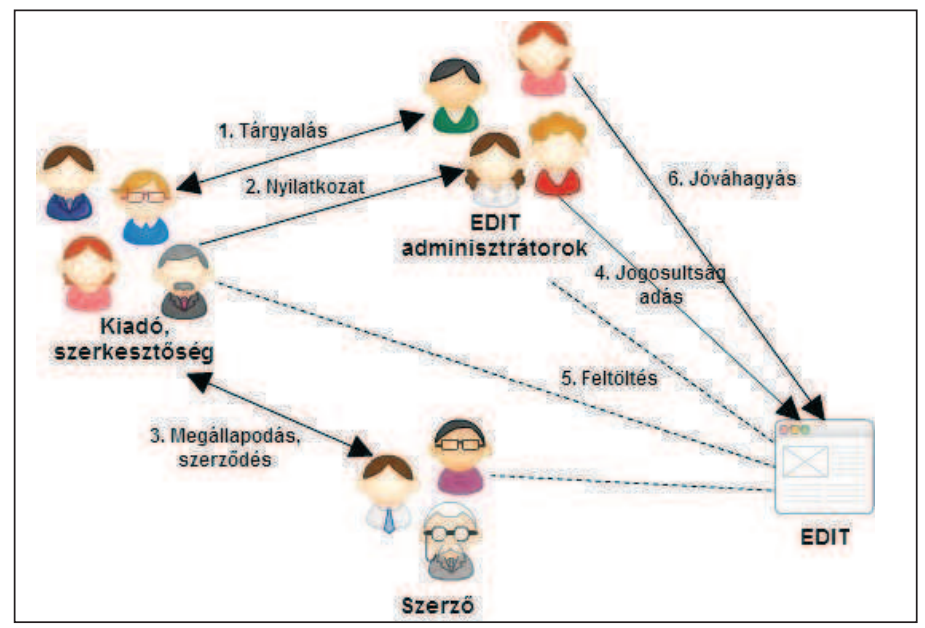

5. ábra. Folyóiratok, kiadványok - folyamatábra

\section{Tudományos publikációk}

A tudományos publikációk feltöltése az MTMT-n keresztül történik a szerző vagy a nevében eljáró adminisztrátor által. Elkerülve az ismételt adatbevitelt, a bibliográfiai adatbázisban (MTMT) már rögzített metaadatokat, valamint az áttöltés során csatolt teljes szöveget hozzáférhetővé tehetjük az EDIT-ben. Ez esetben a feltöltőnek nem szükséges az EDIT-ben is regisztrált felhasználónak lennie, az elindított áttöltés minden esetben megérkezik az EDIT munkafelületére. A gyüjteményeket karonként alakítottuk ki. Az EDIT-be érkező rekordok automatikusan külön kari adminisztrátori munkafelületen landolnak, ahonnan az adminisztrátorok engedhetik ki az EDIT nyilvános felületére. Ez azt jelenti, hogy minden kari adminisztrátornak csak a saját karához tartozó publikációval kell dolgoznia. Az egyéb szervezeti egységek publikációit az Egyetemi Könyvtár munkatársai adminisztrálják. 
Az ELTE-n az MTMT és az EDIT adminisztrátori hálózatának tagjai a hatékonyabb munkavégzés érdekében csaknem teljes átfedésben dolgoznak. A SWORD protokoll használatával a feltöltési folyamat lényegesen felgyorsítható, leegyszerüsíthető, azonban a feltöltési hajlandóság alacsony. Ennek egyik oka lehet, hogy a szerző nem örzi meg publikációjának azt a változatát, amit még közzétehet.

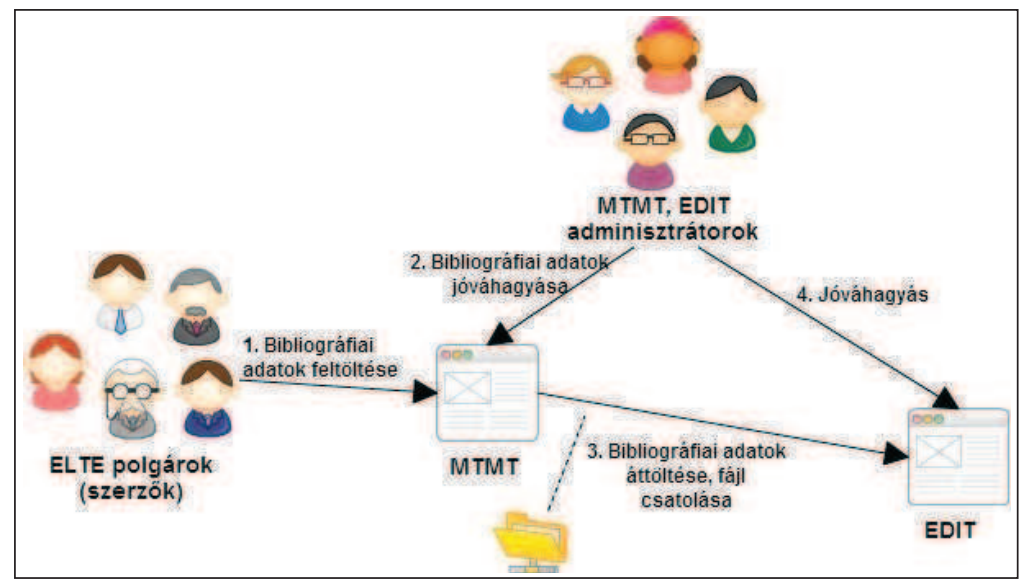

6. ábra. Tudományos publikációk - folyamatábra

\section{Disszertációk}

A doktori disszertációk EDIT-be kerülésének szabályozása hosszú folyamat volt, időbe telt, amíg minden előírásnak meg tudtunk felelni és kidolgoztuk a megfelelő munkafolyamatot. A 2013. augusztus 1. után indított fokozatszerzési eljárás során született disszertációk DOI-azonosítókat kapnak. Az azonosítókat az MTA Könyvtár és Információs Központja biztosítja, képzését, valamint kiosztását az Egyetemi Könyvtár koordinálja. A feltöltés az ELTE doktori hivatalainak együttmüködésével történik, azok munkatársai végzik a szerző írásos meghatalmazásával. Miután a papíralapú disszertáció beérkezik az Egyetemi Könyvtárba, a könyvtár kijelölt munkatársa ellenőrzi a feltöltést. Feldolgozza a disszertáció nyomtatott példányát a könyvtári rendszerben, betölti a disszertáció adatait - beleértve a DOI-t és a katalógus linket is - az MTMT-be. Kiegészíti az EDIT-ben szereplő adatokat az MTMT-azonosítóval, majd jóváhagyja a feltöltést. A DOI-azonosító élesítése után hitelesíti a disszertáció MTMT-s tételét. 


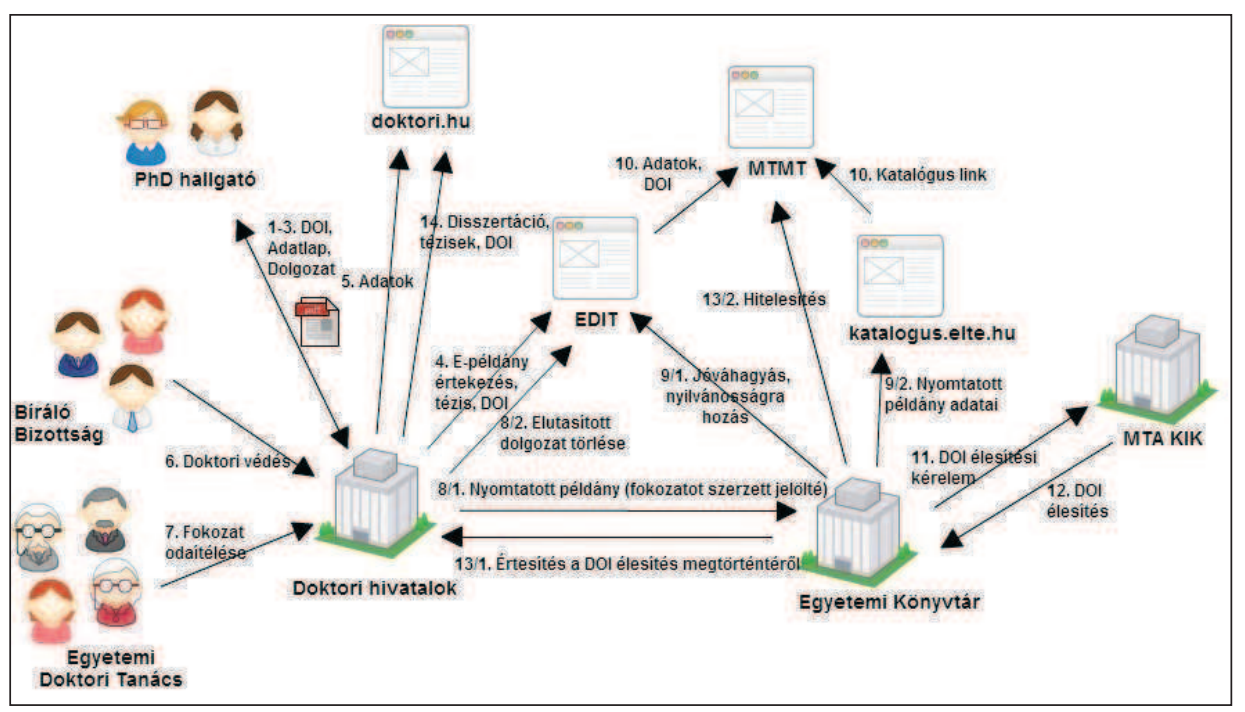

7. ábra. Doktori disszertációk - folyamatábra

\section{Szakdolgozatok}

Fontos igény mind az oktatók, mind a hallgatók részéről, hogy az egyetemen készült szakdolgozatok elérhetők legyenek az EDIT-ben. Központi, egységes szabályozás hiányában a munkafolyamat kialakítása előtt feltérképeztük, hogy milyen gyakorlatok müködnek az ELTE egyes szervezeti egységeiben. Mivel ezek nagyon eltérök voltak, arra a döntésre jutottunk, hogy apró lépésenként haladunk, és csak fokozatosan, egy-egy szervezeti egységet kiválasztva fogjuk bevezetni a repozitóriumi feltöltést. Három tanszékről összesen 43 dolgozat került az EDIT-be, két különböző munkafolyamatot meghatározva. Az elsőnél maguk a hallgatók töltötték fel dolgozataikat, ehhez egyéni regisztrációval és feltöltési jogosultsággal kellett rendelkezniük. A feltöltéseket a kari EDIT adminisztrátor ellenőrizte, majd jóváhagyta. Az első esetben külön tanszéki igény volt a szakdolgozatokhoz kapcsolódó bírálatok archiválása is, ezeket a kari adminisztrátor helyezte el a tudástárban. A dolgozatok elérhetőségét az ELTE IP tartományára korlátoztuk, míg a bírálatok zártan kerültek feltöltésre. 


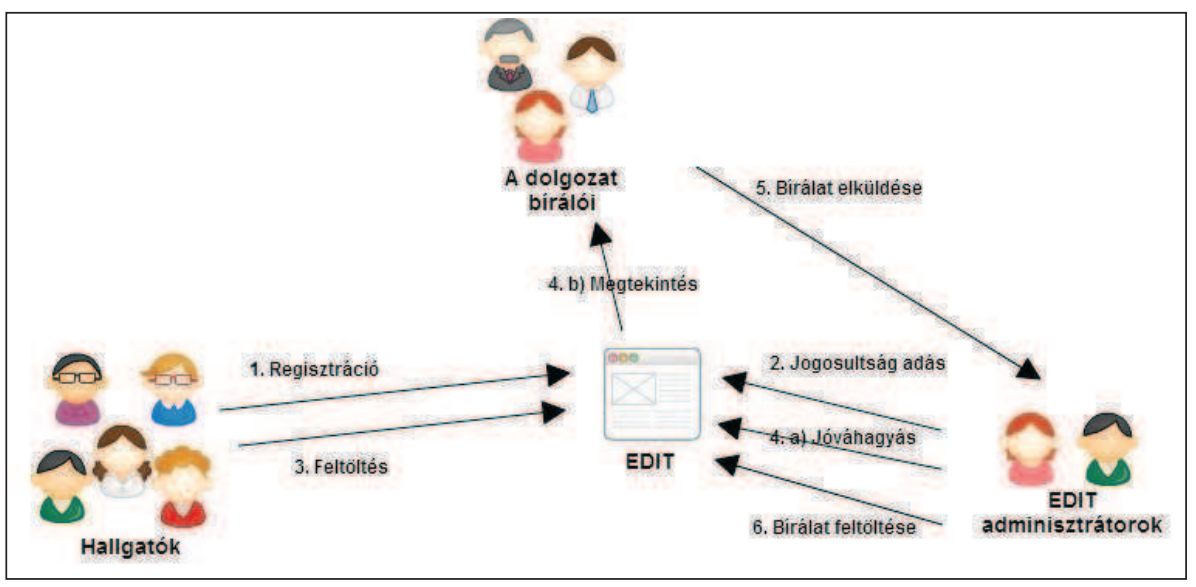

8. ábra. Szakdolgozatok 1. eset - folyamatábra

A másik két tanszéken született szakdolgozatokat egy egyszerübb munkafolyamat követésével helyeztük el az EDIT-ben. Itt, miután a hallgatók kitöltötték és aláírták az elhelyezési megállapodást, a kari EDIT adminisztrátor maga végezte el a feltöltést és a jóváhagyást is.

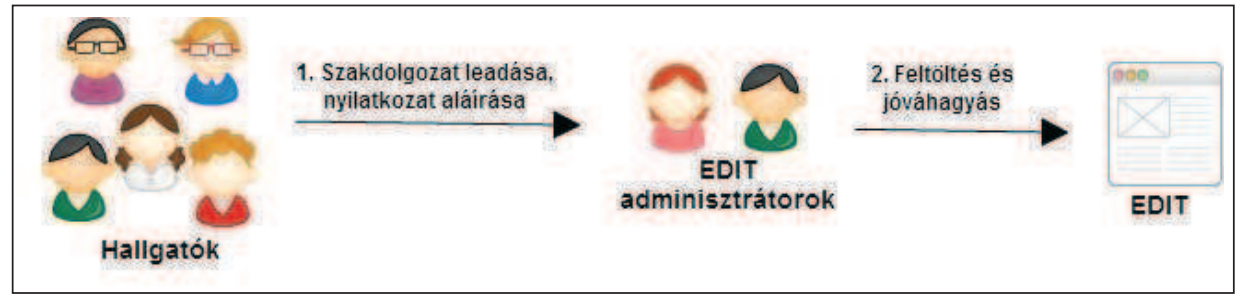

9. ábra. Szakdolgozatok 2. eset - folyamatábra

A két folyamatot értékelve arra a megállapításra jutottunk, hogy kis hallgatói létszámnál, egy-két tanszék bevonásával mindkét módszer az egyéb könyvtárosi feladatok mellett is elvégezhetö, azonban az egész ELTE-re kiterjesztve, a jelenlegi adminisztrátori létszámmal nehézségeink adódnának. Talán megkönnyítené a helyzetünket, ha az EDIT-et a tanulmányi rendszerrel összekapcsolva részben automatizálhatnánk a folyamatot.

\section{Regiszterek, kereső szolgáltatások}

Az MTMT-hez kapcsolt repozitóriumoknak, így az EDIT-nek is önértékelésen alapuló minősítésen kell átesniük. Ezáltal az üzemeltetők és a fel- 
használók megbizonyosodhatnak arról, hogy a repozitórium szolgáltatásai megfelelő színvonalúak, megbízhatók, hosszú távon biztonságosak, továbbá metaadataikat szabványos protokollokon keresztül osztják meg. A minősítési rendszer többlépcsős. Azok a tudástárak, amelyek megfelelnek az elöírt feltételeknek, minősített repozitórium címet kapnak.

Az EDIT-hez hasonló adattárak müködésének fontos része az aggregáló-szolgáltatásokkal való együttmüködés. A tartalmaknak, illetve metaadataiknak az elérhetőségét az EDIT OAI-PMH (Open Archives Initiative Protocol for Metadata Harvesting) kompatibilitása teszi lehetővé, így a regiszterek (mint például az OpenDOAR) be tudják gyüjteni a dokumentumokat.

Regisztráltuk az EDIT-et az OpenDOAR-ban, OpenAIRE kompatibilisek lettünk, megtalálhatók vagyunk a The University of Illinois Data Provider Registry-ben (DPR Celestial). Továbbá folyamatban van az Europeana és a Dart-Europe regisztrációnk.

Az EDIT-et folyamatosan fejlesztjük, jelenleg egy nagyobb, több verziót átívelő verzióváltáson dolgozunk. ${ }^{1}$ A tárolni és közreadni kívánt dokumentumok széles körét a jövőben is igyekszünk megtartani, így például a mai konferencián elhangzott előadás-prezentációk is helyet kapnak repozitóriumunkban. Apró lépésekkel igyekszünk nagy eredményeket elérni.

\section{Rezümé}

Az Eötvös Loránd Tudományegyetem Digitális Intézményi Tudástára (EDIT) az Egyetemen létrehozott dokumentumok tárhelye, archívuma.A tárolni és közreadni kívánt dokumentumok sokszínüsége a tartalom feltöltésében, a gyarapításban is megmutatkozik. Az egyes gyüjtemények gyarapítása különböző munkafolyamatot igényelhet, melyekben az ELTE polgárok szerepe más és más lehet. Az EDIT-be jelenleg háromféleképpen tölthetünk fel dokumentumot, azonban a kialakított folyamatok egy-egy módszeren belül is eltérhetnek, attól függően, hogy milyen előkészítő vagy utómunkát igényelnek. Ezért minden nagyobb egységnél folyamatleírást, szemléltetéséhez pedig folyamatábrát készítettünk.

${ }^{1}$ A 2015 decemberi egyhetes leállást követően új verzióval tért vissza az EDIT. A DSpace szoftver hosszú ideig használt 3.2-es verzióját 5.1-re, majd idén januárban 5.4-re frissítettük, ezzel a jelenleg elérhető legújabb verziót alkalmazzuk. 


\section{Small steps, big jumps \\ of the ELTE Digital Institutional Repository}

The Eötvös Loránd University's Digital Institutional Repository (EDIT) is the storage of documents and archives. The diversity of documents that we want to store and publish is also seen of content upload, of enrichment. The enrichment of individual collections requires different workflow, in which the role of ELTE citizens is different. At present, there are three ways of uploading documents. The created processes may be different, depending on what kind of preparatory work or post-production is needed. Therefore, we made process description and flow charts to illustrate all major units.

VIRÁG GABRIELLA

EDIT központi adminisztrátor ELTE Egyetemi Könyvtár 


\section{A Debreceni Egyetem elektronikus Archívuma (DEA)}

\section{Impresszum}

ADEA a Debreceni Egyetem intézményi repozitóriuma - s mint ilyen, definíció szerint az egyetemen született tudományos publikációk gyüjtésére, szolgáltatására, archiválására és a nyílt hozzáférés biztosítására alkalmas rendszer.

A Debreceni Egyetem Egyetemi és Nemzeti Könyvtár (DEENK) az egyetem Szilárdtest Fizikai Tanszékének kezdeményezését átvállalva kezdte el 2006 tavaszán az intézményi elektronikus archívum kialakítását (http://[-] dea.lib.unideb.hu), melynek üzemszerü müködtetésére hivatalos felhatalmazást 2006 novemberében kapott. A DEENK-nek a Debreceni Egyetem Szenátusa által elfogadott „Müködési Rend”-jében az alapszolgáltatások között szerepel a DEA fejlesztése, gondozása és üzemeltetése. Ezzel megtettük az első jelentős lépést ahhoz, hogy az Archívum az Egyetem infrastruktúrájának szerves részévé, a tudományos munkafolyamat alapelemévé váljon.

A kezdeményező tanszék a DSpace keretrendszert választotta, ezért a DEA ezt a szoftvert használja. Az egyetemen beszerzésre választott tekintélyes méretü tárhely alkalmas az összegyüjtött dokumentumok szolgáltatására és hosszú távú tárolására. A rendelkezésre álló 4 terabájtnyi tárolókapacitásból jelenleg 1,7 TB-t foglalnak el az archivált anyagok.

$\mathrm{Az}$ intézményi repozitórium fenntartása és hatékony müködtetése összehangolt csapatmunkát igényel. A zökkenőmentes napi működtetés az adminisztrációért felelős technikai szakember hatásköre: gyüjtemények kialakítása és kezelése, a jogosultságok meghatározása és beállítása, a könyvtárosok és felhasználók képzése és tájékoztatása. Könyvtárosok foglalkoznak a felhasználókkal való kapcsolattartással és kapcsolatépítéssel, illetve a repozitórium egyetemi, országos és nemzetközi szintü népszerüsítésével. A korszerü, felhasználói igényeket és a technológiai újításokat is követő szolgáltatás fenntartását a csapatba részmunkaidöben kapcsolódó szoftverfejlesztő munkatárs biztosítja, míg a DEA technikai üzemeltetése az egyetem informatikai infrastruktúrájába ágyazva az Informatikai Szolgáltató Központ feladata.

A DEA müködésének tizedik évfordulóját számos változással ünnepeltük meg: verziófrissítést, új arculat kialakítását és az archívum szerkezetének radikális újragondolását végeztük el. 


\section{Szerkezet}

A DSpace fejlesztői elgondolásának megfelelően a DEA szerkezete kategóriákra, alkategóriákra és gyüjteményekre tagolódik. A DEA müködésének első évtizedében egyre sokasodtak a különböző igények szerint kialakított gyüjtemények, melyek alapvetően az egyetem szerkezetét követték, s lassan átláthatatlanná tették az archívum egészét.

2014-ben az Egyetem felépítési rendjét követő struktúrát dokumentum-centrikus rendszerezés váltotta fel. Az egyes gyüjteményeket önálló szolgáltatási felülettel láttuk el, így a doktori dolgozatok, hallgatói dolgozatok, egyetemi publikációk és digitalizált tartalmaink közvetlen eléréssel rendelkeznek. Igényesen kialakított egységes dizájn öleli egybe a gyüjteményeket, ugyanakkor eltérő színvilág jelzi azok határait. Ez az alapvetően felhasználó szempontú szerkezeti felállás lehetővé teszi azt is, hogy az Egyetem struktúrájában lezajló változásoktól függetlenül müködjön a repozitóriumi tartalom-menedzsment.

\section{Tartalom}

ADEA-ban közreadható dokumentumok jogi kereteit a Szerzői jogi törvény (Szjt. 30. §, Szjt. 38. § (5)) és kapcsolódó Kormányrendelet (117/2004. (IV. 28.) Kormányrendelet), a doktori dolgozatok nyilvánosságáról rendelkező utasítások (51/2001. (IV.3) Kormányrendelet 40-41.§, 33/2007. (III. 7.) Kormányrendelet 11. §), a Felsőoktatási törvény (2011. évi CCIV. törvény a nemzeti felsőoktatásról), valamint a Debreceni Egyetem vonatkozó szabályzatai (Doktori szabályzat, Tanulmányi- és Vizsgaszabályzat, Szellemitulajdon-kezelési szabályzat, Szerzői jogi szabályzat és publikációs irányelvek) jelölik ki. Az archívumban tárolható és szolgáltatható dokumentumok körét a felsorolt rendelkezések figyelembe vételével határoztuk meg.

Digitális Könyvtár: a DEENK-ben a folyamatos (tervszerü és projektrendszerü) digitalizálási tevékenység során körülbelül százezer oldalnyi könyv, folyóirat, színlap és kotta digitalizálását végeztük el. Ezek kezelése, szolgáltatása azonban a mennyiségi növekedés és a különböző hozzáférési korlátok miatt nehézkessé vált. Az Szjt. 38. § (5) bek., illetve ennek kiegészítése, a 117/2004. (IV. 28.) Kormányrendelettel lehetővé teszi, hogy a könyvtárak a gyüjteményükben lévő müveket saját helyiségeikben az ezzel a céllal üzembe állított számítógépes képernyőkön tudományos kutatás, vagy egyéni tanulás céljára a nyilvánosság bizonyos tagjai számára szabadon megjeleníthessék. A DEA autentikációs rendszerével, és jól defi- 
niálható hozzáférési szintjeivel megfelelönek bizonyult digitalizált anyagaink, valamint az említett Kormányrendelet értelmében megjeleníthetö dokumentumaink szolgáltatására.

Disszertációk és tézisek: Nemzetközi szinten kiemelkedö, hogy hazánkban már a 2000-es évek elejétöl születtek rendeletek a doktori diszszertációk nyilvános eléréséről, melyet aktuálisan a Felsőoktatási törvény szabályoz oly módon, hogy a doktori értekezés és tézisei egy nyomtatott és egy elektronikus adathordozón rögzített példányának a felsőoktatási intézmény központi könyvtárában történő elhelyezését elöírja. E rendelkezés értelmében a DEA-ban tárolhatók és korlátozás nélkül szolgáltathatók a Debreceni Egyetem doktori iskoláiban elfogadott disszertációk és azok tézisei. A nyilvánosságra hozatal részletes szabályait a doktori szabályzat határozza meg a Debreceni Egyetemen, és e szabályzat értelmében a DEA a doktori fokozatszerzési folyamat részévé vált.

Hallgatói dolgozatok: A Debreceni Egyetemen a Tanulmányi és vizsgaszabályzat rendelkezése szerint a hallgatók számára a tanulmányaikat lezáró szakdolgozat, illetve diplomamunka benyújtását a papíralapú változat mellett kötelező elektronikusan is megtenni. A dolgozatok DEA-ba történő feltöltése az államvizsgára bocsátás feltétele, annak ellenőrzése beépült a karok adminisztratív folyamataiba. Az elektronikus dolgozatok használatát a karok rendelkezése alapján biztosítjuk a DEA-ban, jellemzően a Debreceni Egyetem területéröl. A titkosított szakdolgozatok feltöltésre kerülnek, ám nem érhetők el a felhasználók számára. Az elektronikus forma megőrzéséröl és nyilvántartásáról a DEA üzemeltetőjeként a DEENK gondoskodik.

Publikációk: A DEA-ban a nyílt hozzáférés (open access) eredeti szellemiségének megfelelően tároljuk és szolgáltatjuk az Egyetemen dolgozók kutatási eredményeit a kiadói copyright-politika és a személyes rendelkezések maximális tiszteletben tartásával. 2015-ben a Debreceni Egyetem egységes szabályzatban foglalt állást a publikált tudományos eredményeink gyüjtéséről, valamint a nyílt hozzáférésről. A Szerzői jogi szabályzat és publikációs irányelvek címủ szabályzat eredményeként 2016 elejére közel 3000 cikkhez biztosítunk nyílt hozzáférést a felhasználók számára a DEA Publikációk gyűjteményében.

További gyüjtemények

Oktatási segédletek, elöadásanyagok: Ennek a gyüjteménynek a kihasználtsága nem számottevő jelen pillanatban. Gyakran keresik a könyvtárban 
az egyes intézeti honlapokon elszórtan található elöadásanyagokat, jegyzeteket, vizsgakérdéseket. Ezek ideális, rendszerezett gyüjtőhelye lehet a jövőben az intézményi archívum.

Intézményi dokumentáció: A DEA-ban biztonságosan archiválhatók az egyetemi karok évkönyvei és egyéb dokumentációi.

\section{Biztonság, hozzáférési szintek}

Dokumentumokat az arra jogosult használók tölthetnek fel az archívum gyüjteményeibe. A feltöltéskor alapvető metaadatok (szerző, cím, sorozat, ISBN, ISSN, dokumentumtípus, nyelv, kulcsszavak, összefoglaló stb.) megadása és a dokumentum(ok) feltöltése után egy kötelező (a gyüjtemény egészére vonatkozó) és egy választható (Creative Commons) licenc csatolható a dokumentumhoz. Valamennyi tételt független elérést lehetővé tevő egyedi azonosítóval látunk el, amely nem érzékeny a dokumentum későbbi helyzetváltoztatására. A feltöltést végző személy e-mailben automatikus értesítést kap a müvelet sikeréröl. A hallgatói dolgozatok és a doktori értekezések esetében csoportos feltöltési jogosultságot a tanulmányi rendszer adatai alapján automatikusan kapnak a hallgatók.

$\mathrm{Az}$ repozitórium tartalmának elérését három szintre korlátoztuk. Az első szinten csupán a dokumentum rövid adatai (cím, szerző, a feltöltés ideje) tekinthetők meg, a második szinten hozzáférhetünk valamennyi metaadatához, a harmadik szinten a teljes szöveg is letölthető. A hozzáférési szinteket IP-alapú, illetve jelszavas (LDAP) bejelentkezéssel kontrolláljuk. Feltöltési, illetve elérési jogosultságot egyénenként vagy csoportonként adhat az adminisztrátor.

Az elérés korlátozása nem egyezik meg a nyílt hozzáférés alapelvével, de a technológiát kihasználva más, csak meghatározott felhasználói csoportok számára elérhető tartalmakat is szolgáltathatunk (szakdolgozatok, egyes szakok hallgatóinak készített oktatási anyagok, a könyvtárnak az Szjt. értelmében digitalizált dokumentumai). Ezeknek a tartalmaknak, illetve metaadataiknak az elérhetőségét a regiszter-szolgáltatásokból az adatbázis OAI-PMH kompatibilitása teszi lehetővé, amely a http://re.cs.uct.ac.za oldalon tesztelhetö. A DEA-t a Google indexeli, a dokumentumok teljes szövegéből is ad találatokat. 


\section{Kapcsolatok}

Egyetemi informatikai rendszer

Az Egyetemi és Nemzeti Könyvtár elsőrendủ szempontja, hogy egységes szolgáltatási rendszert alakítson ki, amely felhasználóbarát funkcióival hatékonyan reagál az egyetemi oktatók, kutatók és diákok által támasztott igényekre, gördülékenyen integrálható a kutatási, oktatási folyamatokba.

A repozitórium összeköttetésben áll az Egyetem Neptun tanulmányi rendszerével, amely hallgatói nyilvántartás mellett az oktatásszervezéssel kapcsolatos adminisztratív adatok tárolását is szolgálja. A repozitóriumba való bejelentkezéskor a rendszer azonosítja a felhasználók egyetemi státuszát és jogosultsági köreit.

2014-ben a DEA Publikációk gyüjteményének tartalmát integráltuk az iDEa Tudóstér (https://tudoster.idea.unideb.hu) szolgáltatásba, ahol a bibliográfiai keresések találati listájából vagy a kutatói-, illetve tanszékiintézeti profilokból közvetlenül megnyithatók az elérhető teljes szövegek. Egyre bővül a pályázatokhoz, kutatási projektekhez kapcsolódó profilok és publikációs listák száma. A profilokban többek között a feltöltött, illetve elérhető teljes szövegek számáról is találunk adatokat.

A korábban elkülönülő szolgáltatások összekapcsolása a Tudóstérben egységes felhasználói élményt nyújt, az adatbeviteltől a szerzői vagy tanszéki, intézeti publikációs profilok megjelenítésén át a teljes szövegek eléréséig.

A DEA háttértárként szolgál további szolgáltatások számára is, így a Debreceni Egyetem tehetséggondozó programjának (DETEP) keretében született dolgozatok közül a program által fejlesztett keresőfelületen lehet válogatni, de a háttér-tárolást a dokumentumok részére a DEA adja. A Debreceni Egyetemi Kiadó archív anyagai is a DEA-ban tárolódnak, amely lehetővé teszi a cikkek és könyvek hosszú távú megőrzését, és állandó azonosítását Handle-szám használatával.

\section{Kapcsolat nemzetközi rendszerekkel}

A Debreceni Egyetem Egyetemi és Nemzeti Könyvtár számos olyan nemzetközi program és projekt aktív résztvevője, amelyek a nemzetközi repozitórium-hálózat fejlesztését, az akadálymentes szabványos adatcserét és információhoz való korlátlan hozzáférést tüzték ki célul. A szóban forgó infrastrukturális együttmüködések mindegyikében kulcsszerepet játszik a DEA. 
DART-Europe (http://www.dart-europe.eu): A projekt célja az európai doktori értekezések összegyüjtése és közzététele egy közös platformon keresztül. Az egyik első olyan európai projekt, mely közös adatszolgáltatást célzott meg több repozitórium tartalmára alapozva. A kompatibilitási feltételek között szerepel, hogy (1) az adatokat OAI-PMH protokollon keresztül kell átadni, (2) a metaadat-szerkezetnek a Dublin Core sémát kell követnie, (3) a doktori anyagokat egy külön halmazon (set) keresztül kell arathatóvá tenni, ha mást is tartalmaz az adattár, és (4) a teljes szövegnek nyíltan elérhetőnek kell lennie.

OpenAIRE (https://www.openaire.eu): A projekt célja a nyílt hozzáférés népszerüsítése, és a széleskörü közzététel biztosítását elősegítő támogatási és elektronikus infrastruktúra és adatkezelési stratégia kialakítása. Az Európai Tanács kötelező érvénnyel rendelkezett meghatározott kutatási területeken a 7 . Keretprogramban támogatott projektek eredményeként született közlemények nyílt eléréséről intézményi vagy szakterületi repozitóriumokban. Ezeknek az intézményi és szakterületi repozitóriumoknak az adatait aratja és teszi közzé az OpenAIRE aggregátor szolgáltatása. Ahhoz, hogy az adatok begyüjthetők legyenek, a repozitóriumoknak „OpenAIRE kompatibilis"-nek kell lenniük. Az OpenAIRE kompatibilitás feltétele egyrészt a repozitórium regisztrálása az OpenDOAR nevü regiszterbe, másrészt a repozitóriumnak az OpenAIRE által definiált kimenő adatszerkezetet kell biztosítania.

Europeana (http://www.europeana.eu): ADEA tartalmai az Europeana Travel, az eCloud projektek, valamint a MANDA program közvetítésével jelennek meg az európai digitális könyvtárban az Europeana portálon keresztül. Az Europeana szintén OAI-PMH-n keresztül gyüjti be az adatokat. A megfelelő adatkezelés érdekében kidolgozták az ESE (Europeana Semantic Elements) szabványokat, melyek segítségével a metaadatok tisztítását készítik elő a duplumszüréshez.

\section{Helyi szabályozás}

A DEA fontos szerepet játszik az Egyetem tudományos kommunikációjában. A XXI. század elején a tudományos kutatás és disszemináció egyik legmeghatározóbb hívószava a nyílt hozzáférés. Az open access azt jelenti, hogy a tudományos irodalom az interneten keresztül ingyen és nyilvánosan hozzáférhetö, ezáltal az kutatók teljes szövegeket olvashatnak, másolhatnak, 
tölthetnek le és oszthatnak meg egymással, emellett kereshetnek a szövegekben, hivatkozhatnak azokra és bármilyen módon használhatják, anélkül hogy pénzügyi, jogi vagy technikai akadályokba ütköznének. Az open access mozgalom nemzetközi szintű megerősödése hozzájárul ahhoz, hogy egyre több intézmény teszi magáévá a nyílt hozzáférés politikáját. A kutatók ösztönzése mellett az intézmény feladata olyan kutatás-támogatási infrastruktúra kiépítése is, amely lehetőséget nyújt az egyetemi tudományos eredmények, és ezeken belül is az open access tartalmak begyüjtésére és hosszú távú megőrzésére.

A Debreceni Egyetem Szenátusa az egyetem tudományos küldetésének támogatása érdekében 2015 áprilisában „Szerzői jogi szabályzat és publikációs irányelveket" léptetett hatályba. A szabályzat célja szerzői müvek létrehozásának elősegítése a létrehozott szerzői müvek szerzői jogi aspektusainak szabályozásával; a tudományos publikációk hiteles nyilvántartásának biztosítása; a gazdasági és innovációs fejlődéshez való hozzájárulás azáltal, hogy az egyetem nyílt hozzáférést biztosít a tudományos eredményekhez. A szabályzat hatására az elmúlt közel egy év alatt 3000 fölé emelkedett a nyílt hozzáférésű publikációk száma az egyetemünk intézményi repozitóriumában, melyek a Tudóstér profilokból közvetlenül elérhetők.

\section{Verziófrissítés}

2014-ben új fejezet nyílt a DEA működésében a repozitóriumi keretrendszert adó DSpace nagy léptékű verzióváltása révén, amikoris az 1.5 verzióról 4.1-re váltottunk. Ez a folyamat több új változást is hozott magával. Kiegészítő fejlesztésekre volt szükség, hogy a meglévő, illetve kialakítandó gyüjtemények tartalomveszteség nélkül megjeleníthetők legyenek az új felületen.

Az új verzió számos funkcióval bővült, amelyek a repozitórium által nyújtott szolgáltatások minőségét javítják. Egy Solar alapú Discovery kereső segíti elő a gyors és hatékony tartalom előhívást. Lehetőség nyílt az embargó-kezelésre is, amely során a tudományos cikkek esetén a beállított embargó időszak lejártával a dokumentum automatikusan nyíltan elérhetővé válik az olvasók számára. A repozitóriumból kinyerhető statisztikai adatok spektruma is bővült. A DEA összekapcsolhatóvá vált a Google Analytics rendszerével, amely az oldal látogatottságára vonatkozóan szol- 
gáltat adatokat. Továbbá, saját fejlesztés eredményeként az új verzióval információt kaphatunk arról, hogy hányan látogatják az egyes tételek oldalait, illetve hány letöltés történik a repozitórium gyüjteményeiből.

A verzióváltás új struktúrát és új megjelenést is eredményezett. A gyüjtemények témák szerint lettek létrehozva, és a kiemelt, gyakran használt gyüjtemények színeiben is eltérően jelennek meg. Az új dizájn egy modernebb stílust tükröz, az oldalt a letisztultság és könnyü kezelhetőség jellemzi.

\section{Szabványok}

A repozitórium müködését, és az ehhez kapcsolódó fejlesztéseket számos nemzetközi szabvány határozza meg.

$O A I-P M H:$ Az interoperabilitás alapvető prokollját határozza meg. A tudásvagyon széles körben történő fejlesztéséhez elengedhetetlen, hogy a digitális adattárunk eleget tegyen a más szolgáltatásokkal való együttmüködéshez szükséges feltételeknek. Így fontos, hogy biztosítani tudja az automatikus módon történő adatcserét, melyhez szabványos kommunikációs csatornákat használ, és eleget tesz minden feltételnek, amit a külső szolgáltatások elvárnak. A projektekkel való együttmüködések során figyelni kell arra, hogy minden, a fogadó fél által elvárt metaadat átadásra kerüljön a megfelelő elemként és a megfelelő formátumban. Az adatszolgáltatók a szolgáltatást nyújtók számára biztosítják a metaadatokhoz való hozzáférést ezen módszer segítségével. A szolgáltatást nyújtó fél (Service Provider) le tudja kérdezni az adatszolgáltatónál (Data Provider) fellelhető adatokat, és automatikus kérést indíthat az adatok begyüjtésére, aratására.

SWORD: Ezt a protokollt a JISC támogatásával fejlesztették ki azzal a céllal, hogy kialakítsanak egy olyan egyezményes eljárást, mely lehetővé teszi elektronikus anyagok automatikus betöltését egyidőben több digitális repozitóriumba. Az interfész kialakításával lehetőség nyílt rá, hogy különböző helyekröl lehessen beemelni dokumentumokat az adattárba, akár az irodai programokból történő átemelés segítségével. Mi több, a protokoll segítségével lehetőség van arra is, hogy a betölteni kívánt anyagot egyszerre több adattárban is el tudjuk helyezni.

Shibboleth: A Shibboleth egy elosztott autentikációs rendszer, ahol a tartalmakhoz való hozzáférés az identitás-szolgáltatótól kapott jellemzők alapján történik. A felhasználó úgy vehet igénybe szolgáltatásokat a rendszeren belül, hogy csak egyetlen identitása van az „anyaintézménynél” 
(home institution). Mivel a Shibboleth általában tranziens azonosítókat használ, legjellemzőbb alkalmazási területei azok, ahol nem szükséges a felhasználó pontos kilétét megállapítani, hanem valamilyen jellemző csoporthoz tartozás alapján (például tanár egy bizonyos intézményben, hallgató egy adott kurzuson stb.) engedélyezett a hozzáférés. ${ }^{1}$

\section{Hogyan tovább?}

A DEA fejlesztése több fronton, folyamatosan zajlik. Rendkívül fontos az állandó népszerüsítés, a tudatosság kialakítása a felhasználók, az egyetem vezetése és a könyvtáros kollégák körében is. Újra és újra, újabb és újabb érvekkel kell felkelteni az érdeklődést az új szemléletmódot feltételező szolgáltatás iránt. Szükség van valamennyi dokumentum és gyüjtemény jogi körülményeinek tisztázására: a feladat ellátását nehezíti a szabályozás többféle értelmezhetősége, illetve hiánya egyes dokumentumoknál.

Az átalakítás első évének tapasztalatai alapján elkezdődhet az archívum munkafolyamatainak szabályozása, licencrendszerének átdolgozása, valamint a DEA gyüjteményépítési stratégiájának, archiválási politikájának és eljárásrendjének kialakítása. Elengedhetetlenné vált az állandó személyzet, repozitórium-üzemeltető csoport biztosítása a szolgáltatás rendszerbe való integráláshoz, a metaadatok gondozásához és a közönségkapcsolatok fejlesztéséhez.

\section{Rezümé}

A Debreceni Egyetem repozitóriuma (DEA) 2006 tavaszán jött létre. A müködésének tizedik évfordulóját számos változással ünnepeltük meg: verziófrissítést, új arculat kialakítását, és az archívum szerkezetének radikális újragondolását végeztük el. Az archívum technikailag és tartalmilag is szorosan összefonódik az Egyetem rendszerével. Struktúrája, tartalmi egységei, autentikálási rendszere az egyetemi informatikai fejlesztésekkel összhangban lett létrehozva. A DEA számos nemzetközi program és projekt aktív résztvevője is, amelyek a nemzetközi repozitórium-hálózat fejlesztését, az akadálymentes szabványos adatcserét és információhoz való korlátlan hozzáférést tủzték ki célul. Az innováció és a hálózatosodás jegyében a Debreceni Egyetemi repozitóriumi fejlesztések olyan irányba mutatnak, ahol a hosszú távú és fenntartható müködést a hazai és nemzetközi szabványoknak való megfelelés, illetve az Egyetemi Könyvtáron belül egy állandó repozitóriumi fejlesztő és szolgáltató csapat biztosítja.

${ }^{1}$ Bajnok Kristóf: Autentikációs és autorizációs infrastruktúrák. = Híradástechnika, 61. évf. 2006. 6. sz. 29-34. p. 


\section{The Electronic Archive of the University of Debrecen (DEA)}

The repository of the University of Debrecen was established in 2006. The 10th anniversary of its foundation is celebrated by numerous changes: software update, new design and a structural transformation. The repository is closely linked to the IT system of the University both in content and technological setup: the structure, collection units and authentication system have all been created in line with the university developments. The repository also actively participates in international programs and projects which aim at expanding the global repository network, a barrier-free data exchange and open access to information. In order to advance innovation and networking, the developments of the university repository wish to achieve a long-term, sustainable operation by corresponding to international standards and by organizing a library team responsible for the database developments and services.

KARÁCSONY GYÖNGYI

föigazgató

DEENK 


\section{MTMT: megújulás és lehetőségek}

A Magyar Tudományos Mủvek Tárára (MTMT) a tudományos-könyvtári közösség általában mint szcientometriai adatbázisra tekint - mi most a tudományos bibliográfiák hosszú hagyományának folytatójaként mutatjuk be, megvizsgálva az adatbázisban rejlő lehetőségeket, sorba véve a kihívásokat, amelyekkel szembe kell nézzünk az új funkció kialakítása során.

Nem vállaljuk el a tudományos szakirodalmi bibliográfiák teljes történetének ismertetését, csak egyetlen tudomány - a csillagászat - területéről hozunk néhány példát. Friedrich Weidler Wittenbergben 1755ben kiadott Bibliographia Astronomica-ja ma is jó segédeszköze a régi csillagászati könyvek gyüjtőinek - hasonmás kiadásban is elérhető. A párizsi Observatoire igazgatója, Jerome Lalande 1803-ban adta ki a Bibliographie Astronomique-t, amit 1882 és 1889 között három kötetben kiadott Bibliographie General de L'Astronomie követett, J. C. Houzeau és A. Lancaster munkája. A XX. században a csillagászati bibliográfia készítése rendszeres tevékenységgé vált, Walter Wislicenus indította el az Astronomischer Jahresbericht-et a század elején ${ }^{1}$, ami 1969-tôl átadta helyét a J. Springer kiadásban megjelent, immár angol nyelvü Astronomy and Astrophysics Abstracts-nak. A mai - immár heti frissítéssel müködő, csak digitális formában létező - utód a NASA/SAO Astrophysics Data System $(\mathrm{ADS})^{2}$. Sokat mond a tudomány nemzetközi központjainak eltolódásáról, ha a bibliográfiák szerkesztőinek nemzetiségét, kiadásuk helyét megfigyeljük: Németország, Franciaország, ismét Németország végül az Amerikai Egyesült Államok. Amikor ezek a bibliográfiák megjelentek, elsősorban a tudományos kutatás eszközei voltak. Ma a Bibliographia Astronomica már inkább antikváriusoknak érdekes, Lalande bibliográfiáját és a „Houzeau-Lancaster” köteteit a tudománytörténészek forgathatják,

${ }^{1}$ Duerbeck, H. W.: Walter F. Wislicenus and Modern Astronomical Bibliography. = The Multinational History of Strasbourg Astronomical Observatory. Astrophysics and Space Science Library, Vol. 330. 2005. 153. p.

${ }^{2}$ Accomazzi, A. et al.: ADS: The Next Generation Search Platform. = Library and Information Services in Astronomy VII: Open Science at the frontiers of Librarianship. ASP Conference Series, Vol. 492. 2015. 189. p. 
az ADS pedig egyaránt szolgálja a kutatókat és azokat, akiknek az egyéni vagy intézményi kutatást értékelniük kell.

Az MTMT (most ideértve elődeit, a TPA-t és a KPA-t is) a rendszerváltás után átalakuló, nemzetközi megméretésre törekvő hazai tudományosság értékelési igényeinek kiszolgálására jött létre. Bibliográfiai szerepre nemigen törekedhetett mindmáig - a természettudósok számára a tudományos szakirodalomban való tájékozódáshoz nem sok segítséget adott a csupán hazai müveket tartalmazó rendszer, a bölcsészeknek pedig a mindössze néhány éves lefedettség volt elégtelen. A helyzet azonban mára megváltozott.

Egy TÁMOP projekt eredményeként az egyetemek publikációs tevékenysége 2007-ig visszamenőleg a rendszerbe került (az MTA intézményhálózata esetében ez a szinte teljes lefedettség már korábban megvolt, 1992-ig visszamenőleg). A 2015 nyarán módosított MTA törvény (valamint az azzal együtt módosított felsőoktatási törvény) eredményeként a jövőben minden állami támogatás felhasználásával született tudományos publikációt az MTMT rendszerében rögzíteni kell. Arról, hogy a hazai tudományos bibliográfia a következő évek publikációs tevékenységét teljesen lefedje, nem csupán a törvényi kötelezettség gondoskodik, hanem az is, hogy az MTMT adatait a finanszírozó hatóságok az értékeléshez felhasználják. Többé egyetlen állami finanszírozású intézmény sem engedheti meg magának, hogy publikációs tevékenysége hiányosan jelenjen meg az adatbázisban, és a szerzők sem építhetik tudományos karrierjüket anélkül, hogy publikációs és idézettségi adataik ne lennének itt nyilvántartva.

Egyre növekvő időbeli lefedettségével, a megjelenő publikációk egyre teljesebb körü nyilvántartásával az MTMT érdekessé válhat a „hazai” tudományok művelői számára, mint szakirodalmi tájékozódást szolgáló eszköz. Annál is inkább, mert az MTMT bibliográfiai rekordjai mellé bekerültek a müvek interneten elérhető teljes szövegü változataihoz elvezető ugrópontok, szembetűnően jelezve azt a tényezőt is, vajon szabadon, elöfizetés nélkül is elérhető-e az adott mü? Az MTMT szcientometriai funkciója biztosítja azt, hogy az adatbázis müködjön és lényegében minden mü oda bekerüljön. Most megjelenhet emellett a tájékoztató funkció is, bár ez kétségtelenül nem minden tudományterület kutatói számára lesz érdekes.

Mi kell ahhoz, hogy a tudományos tájékoztató, szakirodalmi kereső funkció jól müködhessen? A megfelelö lefedettség alapkövetelményén túl említettük már az MTMT-ben a publikációk teljes szövegü változataira mu- 
tató hiperhivatkozásokat, és az Open Access jelölést. Ahogy a nyílt hozzáférés terjed, ahogyan a hazai repozitóriumok száma gyarapszik, méretük növekszik, egyre több tartalom válik az MTMT-n keresztül elérhetővé - a Magyar Tudományos Mủvek Tára a hazai intézményi repozitóriumok tudományos tartalmainak közös keresőjeként, aggregátoraként müködhet. (A repozitóriumokban nem csupán tudományos tartalmak vannak, szükség van más közös keresőre is az MTMT mellett.)

Míg korábban azzal érveltünk, hogy a törvényi szabályozás és az érdekeltség biztosítja majd a teljes lefedettséget, el kell ismerjük, fontos szerepe lesz annak is, milyen terheket ró majd a kutatókra az adatfelvitel. Már amennyiben nekik kell az adatokat felvinniük. Nem feledkezhetünk meg az adatok minőségéről sem. A magyar tudományos bibliográfiának teljesnek és pontosnak kell lennie, naprakésznek valamint olcsónak. A felsorolt követelmények mindegyikét, akár közülük kettőt-kettőt, esetleg hármat is teljesíthetünk, de mindegyiket egyszerre? A megújuló MTMT-ben a szerzőkre - és bizonyos területeken adminisztrátoraikra - jutó terhelést csökkenteni szükséges. A szerzői vagy adminisztrátori adatfelvitel lehetősége megmarad, ez biztosítja majd a teljességet és a felelős ellenőrzést. Azonban a hazai kiadású müvek esetében a bibliográfiai adatokat egyre inkább a kiadóktól, szerkesztőségektől próbáljuk beszerezni. Az MTA Könyv- és Folyóirat-kiadó Bizottsága által támogatott folyóiratoknál vezettük be elöször ezt a gyakorlatot. Ahol lehet, a jövőben arra törekszünk majd, hogy az adatátvitel automatikus legyen. Mindazon kiadóknál, amelyek adatbázis-alapú szerkesztőségi és publikációs rendszerekkel müködnek, megoldható lesz ez. Gépi adatátvételre törekszünk mind az Akadémiai Kiadó által használt Atypon Literatum platformjából, mind a számos kis ,indie” tudományos folyóirat által használt Open Journal Systems szoftverből.

Említettük, hogy az MTA kutatóhálózatának adatai 1992-től szerepelnek a rendszerben - igény lenne a felsőoktatás adatait is teljessé tenni az 1990-es évek elejéig. Felmerült az MTMT adatainak szisztematikus bövítése még ennél is korábbi időpontokig. Tudományértékelési céllal csak az intézmények tekintetében lehet érdekes visszamenni további évtizedekre, az egyéni tudományos karrierek szempontjából az 1970-as éveknél korábbi időszak már nemigen lehet érdekes. Ám történeti oldalról nem csupán az intézményi bibliográfiák, hanem az egyéni tudósbibliográfiák is érdekesek lehetnek. Az MTA tagjainak bibliográfiáit akár az Akadémia 
alapításáig visszamenőleg fel lehetne vinni. Kérdés, hogy a szcientometriai felhasználhatóság lehetőségének csökkenésével, a tudománytörténeti-bibliográfiai hasznosítás céljával finanszírozható lesz-e az adatbázis hosszú időre visszanyúló kiterjesztése? Vajon létre tudjuk-e hozni id. Szinnyei József bibliográfiájának tudományos müvekre, kutatókra korlátozott modern változatát?

Elengedhetetlen az MTMT jelenlegi szoftverének, a MyCite-nak a lecserélése - szerencsére a 2015 augusztusában befejeződött TÁMOP projekt erre is lehetőséget adott. Sokkal könnyebben használható felület kell a tájékoztató funkció ellátásához. A MyCite2-nek lesz mobileszközökön is használható nyilvános felülete. Kihívást jelent az, hogy a könnyü használhatóság mellett a felület lehetőséget adjon az összetett feltételekkel történő kereséseknek, a találati listák több lépésben való szűkítésének. Az új nyilvános felület kétnyelvü is lesz. Bár az elsődleges célközönséget a hazai kutatók jelentik, az adatbázis kinyílik mind a külföldi kutatók, mind a hazai tudományszerető publikum előtt is.

Nem müködhet a tájékoztató funkció anélkül, hogy a publikációk tudományterületi besorolását el ne végeznénk. Ilyen jelenleg nincs az MTMT-ben, az egyes tudományterületek értékelési igényeinek különbsége csak az értékelő táblázatoknál - tehát az adatbázisból képzett öszszesítéseknél - jelenik meg. Kihívást jelent a megfelelö klasszifikációs séma kiválasztása - különböző tudományrendszertant használ a Web of Science, a Scopus vagy a Library of Congress, különböző az Ortelius vagy a Frascati Fields of Science besorolási rendszere, nem is beszélve a hazai magas szintü tudományterületi felosztásokról (ilyennek tekinthetjük az MTA osztályokra való tagozódását is). Ezek a rendszerek persze többé-kevésbé leképezhetők egymásra. Az MTMT-ben tárolt másfél millió közleményrekord tudományterületi besorolása jelenti a második kihívást. Folyóiratcikkeknél valószínűleg megoldható lesz a besorolás, amennyiben a folyóirat maga besorolható. A könyvek, könyvfejezetek, konferenciacikkek besorolását talán meg lehet kísérelni a szerzők vagy munkahelyeik besorolásával, de az adatbázisban jelenleg ehhez sem áll rendelkezésre megfelelő információ. Határterületeket tárgyaló cikkeknél alighanem csak a szerző tudja majd a besorolást megtenni, egy-egy cikkhez több tudományterület hozzárendelésével.

Felvetődik a kérdés, mi lehet a viszonya az MTMT-nek a hazai könyvtári közösség bibliográfiai projektjeihez? A különböző bibliográfiák gyüj- 
tőköre, céljai különbözőek, de nyilvánvaló kapcsolatok lehetnek. Itt csupán egy projektet említünk most meg: a MATARKA-t, amit az MTMT adminisztrátorai már régóta használnak. Az MTMT visszamenőleges bövítése esetén kínálkozik a MATARKA adatainak felhasználása. Az újonnan publikált hazai tudományos folyóiratcikkek tekintetében pedig talán majd a MATARKA vehet át adatokat az MTMT-ből.

Az MTMT nem csupán hazai vonatkozású publikációk leíró adatait tartalmazza, de az ezekre kapott idézeteket is. (A korábban említett csillagászati bibliográfiák közül a legújabb, az ADS is ilyen.) Az idézetek felhasználásával képet alkothatunk a publikációk hatásáról - ennek a szcientometriai jelentőségével most nem foglalkozunk. A citációs kapcsolatok viszont fontosak az eszmeáramlatok, a tudósok közötti kapcsolatok, kölcsönhatások tanulmányozása szempontjából is. Kopernikusz De revolutionibus-jának recepciótörténetét izgalmas nyomozómunkával lehetett felderíteni ${ }^{3}$ - az MTMT adatainak felhasználásával szinte folyamatosan követhető a tudományos felismerések terjedése, kollaborációk alakulása. (Az idézettségi hálózatok mellett kollaborációs hálózatok is felrajzolhatók, ezek feltérképezéséhez azonban szükséges a külföldi társszerzők azonosítása, intézményi affiliációik rögzítése.) Az idézési kapcsolatok felhasználhatók a tudományos szakirodalmi tájékoztatásban is: segítségükkel megtalálhatók az egy-egy tudományos téma müveléséhez nélkülözhetetlen alapmüvek, vagy éppen a területtel foglalkozó legjobb áttekintő cikkek - ezt a funkciót megvalósították az ADS-ben is.

A mi MTMT-nk szükségszerüen provinciális, a nemzetközi kitekintés, összehasonlítás céljára nem használható. Amíg a nemzeti tudományokban, a magyar nyelvü tudományos irodalomban teljes lefedettséget biztosíthat (amit a nagy külföldi adatbázisok nem tudnak és nem is akarnak, mert ami csak nekünk érdekes, azon nem tudnak eleget keresni), addig a nemzetközi tudományokban sohasem helyettesítheti majd a nagy kereskedelmi adatbázisokat. Ötvözve az intézményes adatimportot a szerzői beavatkozással, a szerzők és a hazai intézményrendszer pontos ismeretével, a kutatóhelyekkel együttmüködésben történő fejlesztéssel a Magyar Tudományos Mủvek Tára olyan adatbázissá válik, amelynél pontosabbat, teljesebbet a piacon beszerezni nem lehet.

${ }^{3}$ Farkas Gábor Farkas: A könyv, amelyet senki sem olvasott. Adalékok a heliocentrikus modellről folytatott vitához. Magyar Tudomány, 176. évf. 2015. 3. sz. 268-274. p. 


\section{Rezümé}

A Magyar Tudományos Művek Tára a nemzeti tudományos bibliográfiai adatbázis az MTA törvény szerint. Elsődleges - és mindezidáig kizárólagos - feladata adatokat szolgáltatni az egyéni és intézményi tudományos teljesítmény méréséhez. Mivel egyre tágabb idöhatárok között rendelkezik teljes lefedettséggel, újabb alkalmazása lehet: a „hazai” tudományok tekintetében szolgálhatja a szakmai tájékoztatást, szakirodalom-keresést.

\section{MTMT: renewal and prospects}

The Database of Hungarian Scholarly Works (Magyar Tudományos Mủvek Tára, MTMT) gains new applications. Besides supplying statistics for scientometrics it is becoming a scholarly literature discovery tool - at least for disciplines publishing in Hungarian, on Hungarian-related subjects.

HOLL ANDRÁS

informatikai föigazgató-helyettes

MTA KIK 


\section{A repozitóriumok üzemeltetésének jogi kérdései}

Az adott egyetem vagy intézmény tudományos tevékenységét napjainkban a repozitóriumok reprezentálják leginkább, amelyeket általában a könyvtárak üzemeltetnek, ezért előadásomban szeretném összefoglalni e dokumentumés publikációs szerverek üzemeltetése kapcsán felmerülő jogi kérdéseket.

Fontosnak tartom már az elején leszögezni, hogy a nyílt hozzáférésü dokumentumok szerzői jogilag ugyanúgy védettek, mint a hagyományos publikációk.

A nyílt hozzáférés két ajánlott módja közül most a zöld útra szeretnék koncentrálni, ami a publikált tudományos szövegeknek az intézményi vagy tematikus dokumentumszerveren, repozitóriumban történő archiválását és nyilvánossághoz közvetítését jelenti nyílt hozzáféréssel.

Amikor egy szerző létrehozza új alkotását, a törvény erejénél fogva automatikusan létrejön a szerzői jogi védelem is. A szerzőt ettöl a pillanattól kezdve megilleti a személyhez füződő jogok és vagyoni jogok összessége.

A szerzői vagyoni jog elsődleges célja, hogy a szerzőnek (ill. a jogosultaknak) müve bármely felhasználása után anyagi ellentételezést, díjazást írjon elő. Tapasztalataim szerint müfelhasználás alatt alapvetően mást értenek a könyvtárosok és a jogászok. Tulajdonképpen szerzői jogi szempontból „felhasználás” alatt a többszörözést és a mű mások számára történő érzékelhetővé tételét értjük.

Hatályos szerzői jogunk példázódó módon rögzíti azokat a konkrét felhasználási módokat ${ }^{1}$, amelyek esetén a szerzőt díjazás, ellenszolgáltatás illeti meg. Azonban a mü bármilyen más, mások számára történő érzékelhetővé tétele is engedélyköteles.

Esetünkben két műfelhasználási mód releváns, a digitális többszörözés és az ún. on-demand nyilvánossághoz közvetítés.

Az archiválás, a digitalizálás a szerzői jog fogalomrendszerében többszörözésnek minősül, hiszen ahhoz, hogy a müvet analógból digitális formátumúvá alakítsuk annak másolására van szükség.

${ }^{1}$ Szjt. 17. §. Forrás: http://net.jogtar.hu/jr/gen/hjegy_doc.cgi?docid=99900076.TV [2015. 08. 01.] 
A szerző kizárólagos joga, hogy művét többszörözze, és hogy erre másnak engedélyt adjon² ${ }^{2}$ Az Szjt. 18. § (2) bekezdése szerint a mü tárolása digitális formában elektronikus eszközökön többszörözésnek minősül, amely szintén a szerző kizárólagos jogai közé tartozik.

Továbbá az Szjt. 26. § (8) bekezdése a szerző kizárólagos jogai közé sorolja műve online felhasználásának engedélyezését is. „E joga kiterjed különösen arra az esetre, amikor a müvet vezeték útján vagy bármely más eszközzel vagy módon úgy teszik a nyilvánosság számára hozzáférhetővé, hogy a nyilvánosság tagjai a hozzáférés helyét és idejét egyénileg választhatják meg."’3 (Ezt nevezzük lehívásos vagy ún. on-demand típusú hozzáférésnek.) Ez a felhasználási mód valósul meg, egyrészt amikor a müveket számítógépes hálózat útján, online tesszük hozzáférhetővé, másrészt pedig amikor a műveket eljuttatjuk a szolgáltatást igénybe vevő közönség egyes tagjaihoz.

Ezenkívül az Szjt. 27. §-a értelmében a szakirodalmi müvek és a nagyobb terjedelmü, nem színpadra szánt szépirodalmi mủvek (pl. regények) online felhasználását a jogalkotó a kizárólagos engedélyezési jog megszerzéséhez köti.

A nyilvános szolgáltatásokat nyújtó könyvtárak esetében ez azt jelenti, hogy a szakirodalmi mủvek, tudományos publikációk archiválása, digitalizálása az Szjt. 35. § (4) bekezdése alapján engedélykérés és díjfizetés nélkül lehetséges, amennyiben az jövedelemszerzés vagy jövedelemfokozás célját közvetve sem szolgálja, és az Szjt.-ben felsorolt valamelyik felhasználási célt szolgálja. Ugyanakkor a digitalizált szakirodalmi müvek online felhasználása, vagy on-demand nyilvánossághoz közvetítése csak a jogtulajdonosokkal kötött felhasználási szerződés birtokában lehetséges.

Jogtulajdonos az, akitől engedélyt kell kérni a mü felhasználására, illetve akinek díjat kell fizetni a mü felhasználásáért. Ez tulajdonképpen lehet maga a szerző vagy aki vagyoni jogait öröklés vagy átruházás, átszállás alapján megszerzi.

Amennyiben a szerző munkaviszony szerinti munkaköri kötelezettsége keretében készít el a müvét (ún. szolgálati mü) ${ }^{4}$, arra nézve a vagyoni jogok az Szjt. alapján a munkáltatóra szállnak át.

Fontosnak tartom megjegyezni, hogy a munkaviszonynak a mü keletkezésekor kell fennállnia, a jogkövetkezményeket nem érinti a munka-

\footnotetext{
${ }^{2}$ Szjt. 18. § (1) bek.

${ }^{3}$ Szjt. 26. § (8) bek.

${ }^{4}$ Szjt. 30. §
} 
viszonynak ezt követően történő megszünése. Szükséges továbbá, hogy a szerzőnek a mü létrehozása kifejezetten munkaköri kötelezettségét képezze, amelyre vonatkozólag a szerző munkaköri leírása, munkaszerződése az irányadó.

A müre vonatkozó vagyoni jogokat a mü átadásával a munkáltató az Szjt. alapján megszerzi. E jogszerzés azonban nem teljes körü, mert a munkáltató nem szerzi meg a szerző csak kötelező közös jogkezelés útján érvényesíthető méltányos díjigényeit (például üreskazetta, reprográfiai, nyilvános haszonkölcsönzési jogdíj stb).

Természetesen a munkáltató az általa megszerzett vagyoni jogokkal szabadon rendelkezhet. A müvet

- titokban tarthatja vagy felhasználhatja,

- másnak bármilyen terjedelmü felhasználást engedhet, vagy

- a vagyoni jogot magát is átruházhatja.

Ha a munkáltató harmadik személyeknek ad át a müre vonatkozó felhasználási jogokat, akkor az általános szabály szerint a szerzőt megfelelő díjazás illeti meg. A díjigény érvényesen (természetesen csak írásban és kifejezett nyilatkozattal) ki is zárható.

Gyakori, hogy a szerző egy kiadónak engedi át a számunkra releváns müfelhasználási jogait. A legtöbb kiadó engedélyezi a publikációk intézményi vagy tudományterületi repozitóriumokban történő párhuzamos elhelyezését. Ahhoz, hogy egy szerző biztosítsa magának a jogot cikkének online repozitóriumban vagy saját intézményének ingyenesen elérhető dokumentumszerverén történő párhuzamos elhelyezésére, a kiadóval kötött szerződést ennek értelmében kell megkötnie.

Az úgynevezett SHERPA/RoMEO lista részletesen tájékoztat arról, hogy a kiadók milyen kiadói politikát vallanak a párhuzamos elhelyezés kérdésében. E lista tartalma azonban jogilag nem döntő érvényü, inkább csak orientáló jellegű számunkra. Kétség esetén mindig a hatályos kiadói szerződés érvényes!

Lényeges, hogy minket, repozitórium üzemeltetőket a jogtulajdonos biztosítson arról, hogy jogosult az adott müfelhasználásra engedélyt adni, amennyiben szolgálati müről van szó, akkor az adott munkáltatótól, mint jogtulajdonostól, kell engedélyt szereznünk a műfelhasználásra. Amenynyiben a releváns műfelhasználási jogokat a szerző átadta egy kiadónak, úgy a kiadó nyilatkozatát kell beszereznünk arról, hogy az adott müvek 
szerzőivel kötött megállapodások alapján rendelkezik a müvek felhasználási jogaival és jelen nyilatkozat vagy szerződés aláírásával igazolja és szavatolja, hogy a szerződésben meghatározott felhasználási jogok átruházására jogosult.

Összefoglalva fontosnak tartom a kiadóval vagy a jogtulajdonossal kötött szerződésben rögzíteni, hogy a kiadó/jogtulajdonos szavatol azért, hogy a művön nem áll fenn harmadik személynek olyan kizárólagos szerzői vagyoni joga, amely a repozitórium üzemeltetőjének jogszerzését és müfelhasználását korlátozná vagy akadályozná. E tekintetben más harmadik személyt a repozitórium üzemeltetőjével szemben semmiféle jog nem illeti meg, és ebböl eredően a repozitórium üzemeltetőjével szemben semmiféle jogcímen díjigény nem érvényesíthető.

Szintén nagyon sarkalatos része a megállapodásnak - véleményem szerint - egy esetleges jogsértés esetén felmerülő felelősség kérdése.

A repozitórium üzemeltetőjének egyfelöl biztosítania kell a müvek védelmét a szerzői jog védelmére szolgáló hatásos müszaki intézkedéssel. Az Szjt. meghatározza a hatásos müszaki intézkedés fogalmát: müszaki intézkedés minden olyan eszköz, alkatrész vagy technológiai eljárás, illetve módszer, amely arra szolgál, hogy a szerzői jog jogosultja által nem engedélyezett cselekményeket - rendeltetésszerü müködése révén - megelőzze, illetve megakadályozza. ${ }^{5}$ Másfelől tudjuk, hogy tulajdonképpen nem létezik olyan hatásos müszaki intézkedés, amelyet ne lehetne feltörni, megkerülni.

Ezért fontos lefektetni a szerződésben egyrészt a technikai paramétereket, vagy legalább azt, hogy a felek kijelentik, hogy teljes mértékben tisztában vannak a védelmi DRM-technológia tulajdonságaival, müködésével, az abban rejlő lehetőségekkel és annak korlátaival, valamint elismerik, hogy az alkalmazott DRM-technológia megfelel az Szjt. 95. § (3) bekezdésében meghatározott hatásos müszaki intézkedés fogalmának.

Másrészt szintén fontos lenne rögzíteni, hogy a repozitórium üzemeltetője nem felelős akkor, ha harmadik személy ezt a hatásos müszaki intézkedést megkerüli, és jogtalanul használja fel a védett müveket. A jogtulajdonos ebben az esetben közvetlenül e jogsértő harmadik személlyel szemben érvényesítheti igényét, és a repozitórium üzemeltetőjével szemben semmilyen követelést nem támaszthat.

\footnotetext{
${ }^{5}$ Szjt. 95. § (3) bek.
} 


\section{Rezümé}

Az adott egyetem vagy intézmény tudományos tevékenységét napjainkban a repozitóriumok reprezentálják leginkább, amelyeket általában a könyvtárak üzemeltetnek, ezért a tanulmányomban összefoglalom e dokumentum- és publikációs szerverek üzemeltetése kapcsán felmerülő jogi kérdéseket.

A nyílt hozzáférésủ dokumentumok szerzői jogilag ugyanúgy védettek, mint a hagyományos publikációk. A nyílt hozzáférés ajánlott módjai közül írásomban a zöld útra koncentrálok, ami a publikált tudományos szövegeknek az intézményi vagy tematikus dokumentumszerveren, repozitóriumban történő archiválását és nyilvánossághoz közvetítését jelenti nyílt hozzáféréssel. A nyilvános szolgáltatásokat nyújtó könyvtárak esetében a szakirodalmi múvek, tudományos publikációk archiválása, digitalizálása az Szjt. 35. § (4) bekezdése alapján engedélykérés és díjfizetés nélkül lehetséges, amennyiben az jövedelemszerzés vagy jövedelemfokozás célját közvetve sem szolgálja, és az Szjt.-ben felsorolt valamelyik felhasználási céllal összhangban van. Ugyanakkor a digitalizált szakirodalmi müvek online felhasználása vagy on-demand nyilvánossághoz közvetítése csak a jogtulajdonosokkal kötött felhasználási szerződés birtokában lehetséges.

Gyakori, hogy a szerző egy kiadónak engedi át a számunkra releváns müfelhasználási jogait. A legtöbb kiadó engedélyezi a publikációk intézményi vagy tudományterületi repozitóriumokban történő párhuzamos elhelyezését. Ahhoz, hogy egy szerző biztosítsa magának a jogot cikkének online repozitóriumban vagy saját intézményének ingyenesen elérhető dokumentumszerverén történő párhuzamos elhelyezésére, a kiadóval kötött szerződést ennek értelmében kell megkötnie.

A kiadóval vagy a jogtulajdonossal kötött szerződésben célszerü rögzíteni, hogy a kiadó/jogtulajdonos szavatol azért, hogy a müvön nem áll fenn harmadik személynek olyan kizárólagos szerzői vagyoni joga, amely a repozitórium üzemeltetőjének jogszerzését és mủfelhasználását korlátozná vagy akadályozná. Sarkalatos része a megállapodásnak - véleményem szerint - egy esetleges jogsértés esetén felmerülő felelősség kérdése. Fontos lenne lefektetni a szerződésben, hogy a repozitórium üzemeltetője nem felelös akkor, ha harmadik személy a hatásos müszaki intézkedést megkerüli, és jogtalanul használja fel a védett müveket.

\section{Legal aspects of the operation of repositories}

Nowadays the scientific activity of a university or an academic institution is represented principally by the repositories operated by libraries. Therefore I will sum up the issues of law regarding the operations of the document and publication servers. 
It is important to point out at the very beginning, that the open access documents are copyrighted the same way as traditional publications are. I would like to focus on the "green (licensed) road", which is one of the recommended types of open access. This would mean the archiving and making accessible the published scientific texts on institutional or thematic document servers (repositories). Pursuant to paragraph 35 (4) of the Hungarian Copyright Act public libraries may archive and digitize scientific publications without requesting permisssion or paying fees, provided that they have no intention to profit or increase profits even in an indirect way, and the digitisation serves one of the purposes enlisted in the Copyright Act. However, the use of these digitized scientific publications either online or via on-demand supply service requires the written consent of the rightsholder in the form of copyright license agreement.

The author confers often his rights relevant for us to the publisher. Most of the publishers allow publications to be positioned also in an institutional or disciplinary repository. In order to have the right to make his publication accessible in an open access online repository or in the document server of his institution the author needs to include this in the contract with his publisher. It should also be emphasized in the contract that the publisher and/or rightholder warrant that the article is not the work of a third party and/or they have an exclusive right (copyright).

The liability issues and the liquidated damages are also pivotal parts of the agreement in the case of a breach of the contract. Thus, for example, it should be laid down in the contract, that the repository operator is not liable if third parties illegally bypass the technological measures and use the protected works.

AMBERG ESZTER

fökönyvtáros, jogász OSZK Könyvtári Intézet 


\section{Kötetünk szerzői}

Amberg Eszter: Csorba Győző Könyvtár, igazgatóhelyettes (megelőzően: OSZK Könyvtári Intézet, főkönyvtáros, jogász).

Elérhetőség: amberg.eszter@csgyk.hu.

Czinki-Vietorisz Gabriella: ELTE Egyetemi Könyvtár, könyvtáros.

Elérhetőség: vietorisz.gabriella@lib.elte.hu.

Holl András: MTA KIK, informatikai föigazgató-helyettes.

Elérhetőség: holl.andras@konyvtar.mta.hu.

Karácsony Gyöngyi: DEENK, föigazgató.

Elérhetőség: gyk@lib.unideb.hu.

Kiszl Péter: ELTE BTK Könyvtár- és Információtudományi Intézet, intézetigazgató egyetemi docens.

Elérhetőség: kiszl.peter@btk.elte.hu.

Knapp Éva: ELTE Egyetemi Könyvtár, tudományos ügyek referense.

Elérhetőség: knapp.eva@lib.elte.hu.

Szépvölgyi Katalin: ELTE Egyetemi Könyvtár, könyvtáros.

Elérhetőség: szepvolgyi.katalin@lib.elte.hu.

Varga Klára: ELTE Egyetemi Könyvtár, osztályvezető.

Elérhetőség: varga.klara@lib.elte.hu.

Virág Gabriella: ELTE Egyetemi Könyvtár, könyvtáros.

Elérhetőség: virag.gabriella@lib.elte.hu. 
Kiadta az ELTE Egyetemi Könyvtár Felelős kiadó: Kálóczi Katalin főigazgató

Cím: 1053 Budapest, Ferenciek tere 6.

Borítóterv: Hajtmanszki Péter Müszaki szerkesztő: Szabó Panna

Nyomdai kivitelezés: Komáromi Nyomda és Kiadó Kft. 